\title{
Systemic and local regulation of experimental arthritis by IFN- $\alpha$, dendritic cells and uridine
}

\author{
Sudeep Chenna Narendra
}

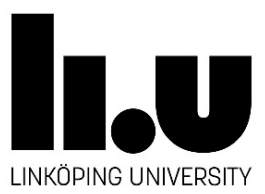

Rheumatology, Autoimmunity and Immune-Regulation (AIR)

Department of Clinical and Experimental Medicine,

Faculty of Health Sciences, Linköping University,

SE-581 85 Linköping, Sweden 
Copyright $(\subset)$ Sudeep Chenna Narendra, 2017

ISBN: 978-91-7685-541-6

ISSN: 0345-0082

Paper I was published in PLOS ONE which publishes all of the content in the articles under an open access license called "CC-BY." This license allows you to download, reuse, reprint, modify, distribute, and/or copy articles or images in PLOS journals, so long as the original creators are credited (e.g., including the article's citation and/or the image credit). Additional permissions are not required.

Paper II has been reprinted with permission from JLB.

Paper III was published in The Journal of Immunology. Copyright 2016. The American Association of Immunologists, Inc.

Printed by LiU-tryck, Linköping Sweden, 2017 
"Known is World, Unknown is Self Known to Unknown is the Real Travel."

\section{- Sri Swamy Poornananda}

"As to diseases, make a habit of two things - to help, or at least, to do no harm."

- Hippocrates 


\section{Supervisor}

Mattias Magnusson, Linköping University, Sweden.

\section{Co-supervisor}

Srinivas Uppugunduri, Linköping University, Sweden.

Alf Kastbom, Linköping University, Sweden.

\section{Faculty opponent}

Natacha Bessis, INSERM UMR1125, Université Paris 13, Bobigny, France

\section{Funding}

This work was supported by the fundings from Swedish Research Council (Vetenskapsrådet, Reumatikerförbundet, Magnus Bergvall Foundation, Gustav V 80-years foundation, the Swedish Association against Rheumatism (Reumatikerförbundet) and Linköping University. 


\begin{abstract}
In this thesis, we have studied the immunological processes of joint inflammation that may be targets for future treatment of patients with arthritis. We focus on the immune-modulating properties of interferon- $\alpha$ (IFN- $\alpha$ ) and uridine in experimental arthritis. The nucleoside uridine, which is regarded a safe treatment has anti-inflammatory properties notably by inhibiting tumor necrosis factor (TNF) release. Because the inflamed synovium in rheumatoid arthritis (RA) is characterised by pathogenic TNF-production, uridine could potentially be a way to ameliorate arthritis. Systemic administration of uridine had no effect on antigeninduced arthritis (AIA), which is a T-cell dependent model where animals are immunized twice (sensitization) with bovine serum albumin (mBSA), before local triggering of arthritis by intra-articular antigen (mBSA) re-challenge. In contrast, intra-articular administration of uridine clearly down modulated development of AIA in a dose dependent manner and inhibited the expression of synovial adhesion molecules, influx of inflammatory leukocytes and synovial expression of TNF and interleukin 6, but did not affect systemic levels of proinflammatory cytokines or antigen-specific T-cell responses. Local administration of uridine may thus be a viable therapeutic option for treatment of arthritis in the future.
\end{abstract}

Viral double-stranded deoxyribonucleic acid (dsRNA), a common nucleic acid found in most viruses, can be found in the joints of RA patients and local deposition of such viral dsRNA induces arthritis by activating IFN- $\alpha$. Here we show that arthritis induced by dsRNA can be mediated by IFN-producing dendritic cells in the joint and this may thus explain why viral infections are sometimes associated with arthritis.

Earlier, to study the effect of dsRNA and IFN- $\alpha$ in an arthritis model, that like RA, is dependent on adaptive immunity, dsRNA and IFN- $\alpha$ were administered individually during the development of AIA. Both molecules clearly protected against AIA in a type I IFN receptor-dependent manner but were only effective if administered in the sensitization phase of AIA. Here we show that the anti-inflammatory effect of IFN- $\alpha$ is critically dependent on signalling via transforming growth factor $\beta$ (TGF- $\beta$ ) and the enzymatic activity of indoleamine 2,3 dioxygenase 1 (IDO). The IDO enzyme is produced by plasmacytoid DC and this cell type was critically required both during antigen sensitization and in the arthritis phase of AIA for the protective effect of IFN- $\alpha$ against AIA. In contrast, TGF- $\beta$ and the enzymatic activity of IDO were only required during sensitization, which indicate that they are involved in initial steps of tolerogenic antigen sensitization. In this scenario, IFN- $\alpha$ first activates the enzymatic activity of IDO in pDC, which converts Tryptophan to Kynurenine, which thereafter activates TGF- $\beta$. Common for IDO-expressing pDC, Kyn and TGF- $\beta$ is their ability to induce development of regulatory T cells (Tregs). We found that Tregs were crucial for IFN- $\alpha$-mediated protection against AIA, but only in the arthritis phase. In line with this, adoptive transfer of Tregs isolated from IFN- $\alpha$ treated mice to recipient animals in the arthritis phase clearly protected against AIA. The numbers of Tregs were not significantly altered by IFN- $\alpha$ but IFN- $\alpha$ increased the suppressive capacity of Tregs against antigen-induced proliferation. This enhanced suppressive activity of Tregs in the arthritis phase was dependent on the earlier activated enzyme IDO1 during the sensitization phase of AIA. Thus, presence of IFN- $\alpha$ at the time of antigen sensitization activates the enzymatic activity of IDO, which generates Tregs with enhanced suppressive capacity that upon antigen re-challenge prevents inflammation. We have thus identified one example of how immune tolerance can be developed, that may be a future way to combat autoimmunity. 


\section{CONTENTS}

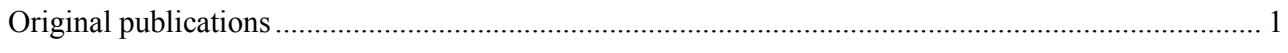

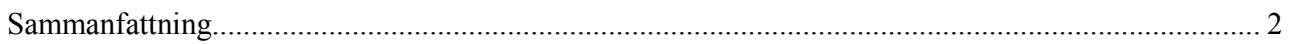

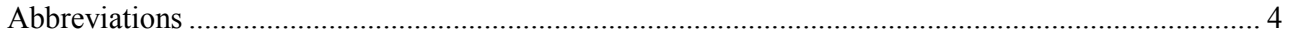

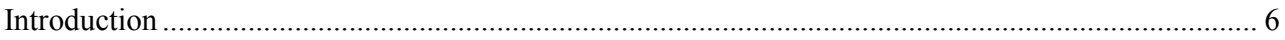

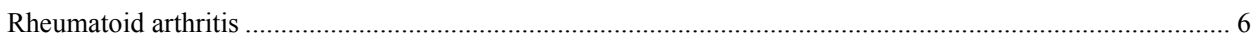

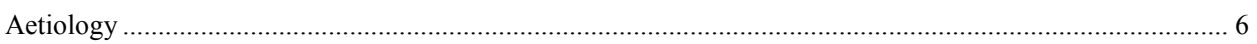

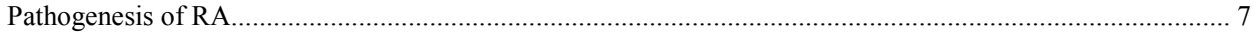

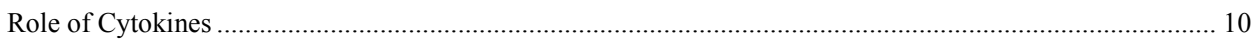

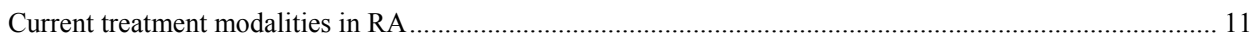

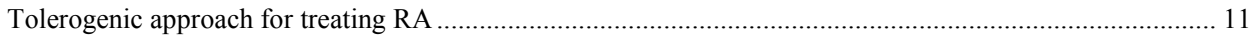

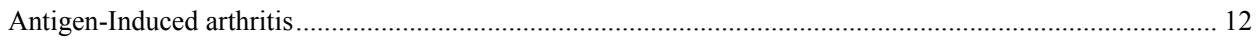

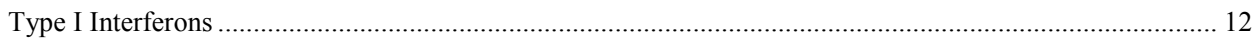

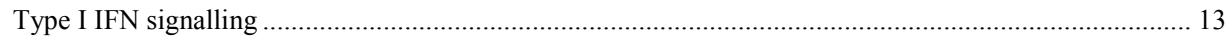

Regulation of T cell responses by type I IFNs ................................................................................. 14

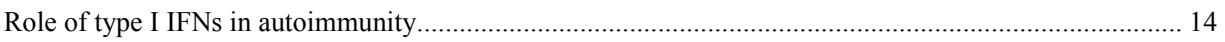

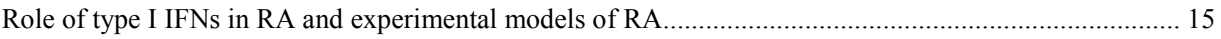

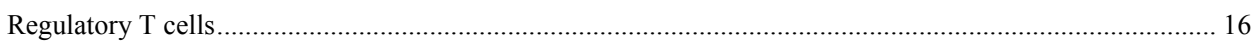

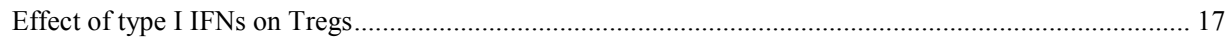

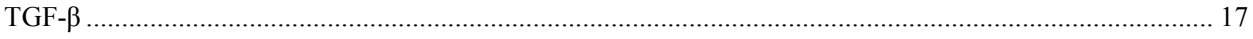

IDO

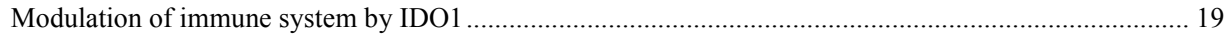

Uridine

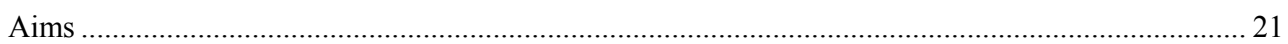

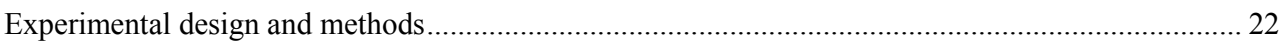

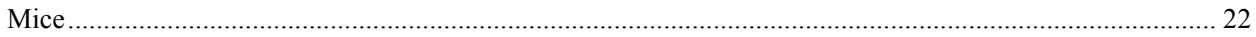

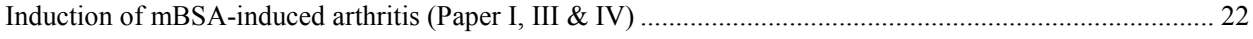

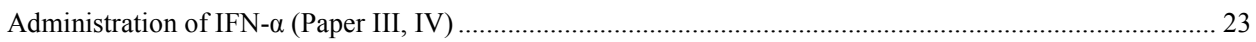

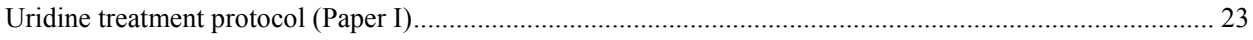

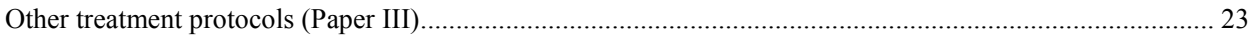

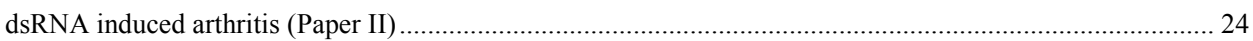

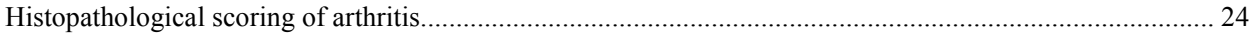

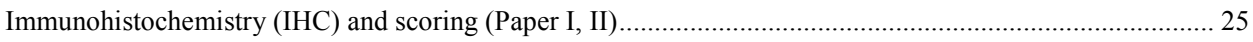

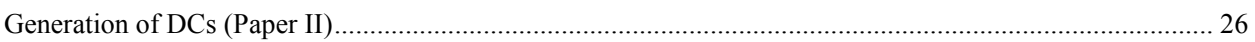

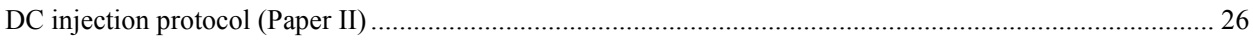

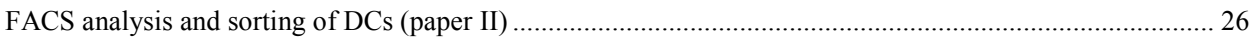

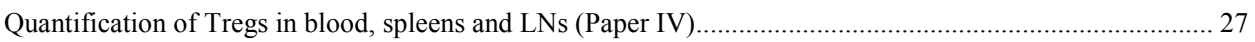

Ex Vivo assessment of antigen-specific proliferation (Paper I, III) ............................................................. 27

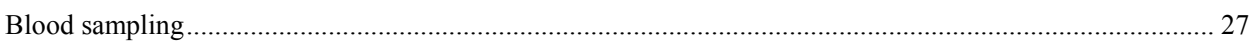

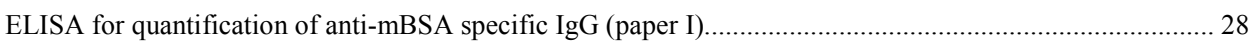




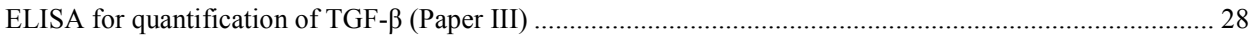

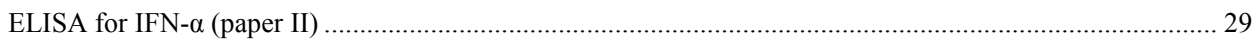

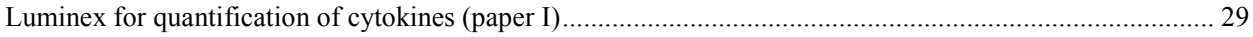

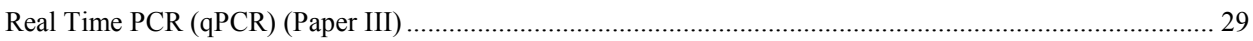

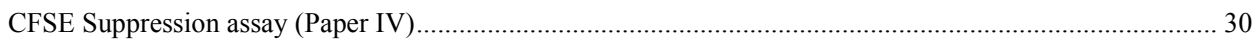

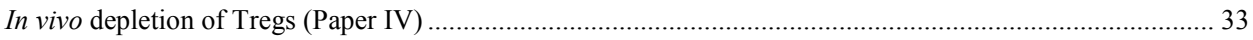

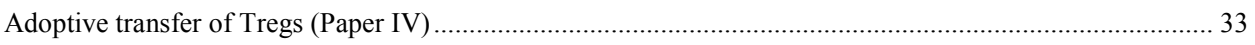

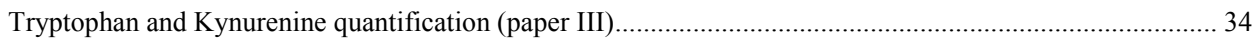

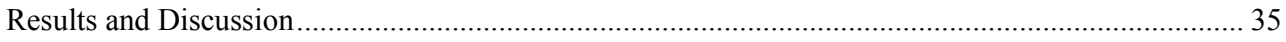

Local but not systemic administration of uridine prevents development of AIA (Paper I) .......................... 35

Systemic administration of uridine does not inhibit development of mBSA-induced arthritis. .................. 35

Local administration of uridine inhibits development of mBSA-induced arthritis in dose dependent manner.

Local administration of uridine suppressed synovial expression of IL-6 \& TNF, synovial cell influx and synovial expression of ICAM-1 \& CD18

Dendritic Cells activated by double-stranded RNA induce arthritis via autocrine type I IFN signalling (Paper II).

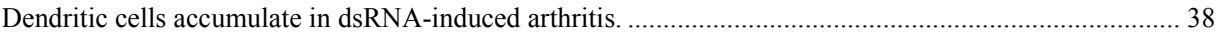

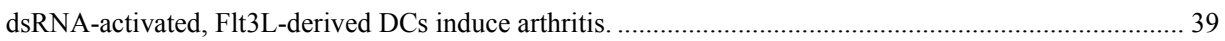

The Arthritogenicity of ds-RNA-activated, Flt3L-derived DCs is dependent on functional IFNAR .......... 40

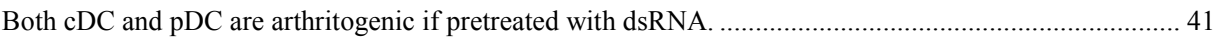

IDO1 and TGF- $\beta$ Mediate Protective Effects of IFN- $\alpha$ in Antigen-Induced Arthritis (Paper III) ................. 43

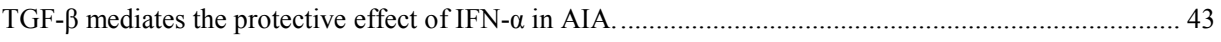

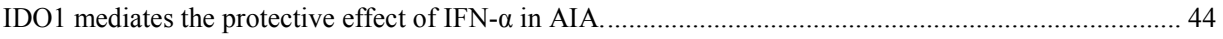

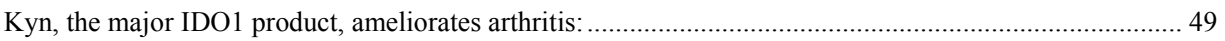

The protective effect of IFN- $\alpha$ in AIA requires presence of $\mathrm{pDC}$ both in the sensitization and arthritis

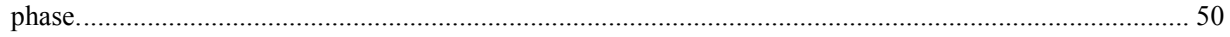

Regulatory $\mathrm{T}$ cells manifest IFN- $\alpha$ mediated protection during antigen-induced arthritis (Paper IV)............. 52

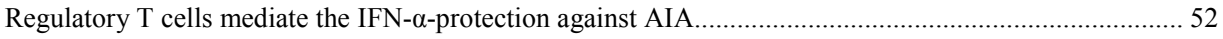

IFN- $\alpha$ treatment in vivo increases the in vitro suppressive activity of regulatory $\mathrm{T}$ cells.......................... 53

Type I IFN signalling in T helper cells is not required for IFN- $\alpha$ protection against AIA......................... 55

Enzymatic IDO activity mediates the increased suppressive capacity of Tregs conferred by IFN- $\alpha \ldots \ldots \ldots . . . .55$

Adoptive transfer of Tregs from mBSA immunized mice protects against mBSA-induced arthritis.......... 57

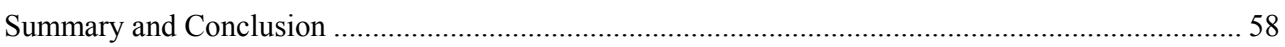

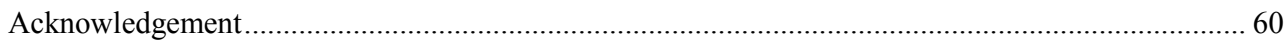

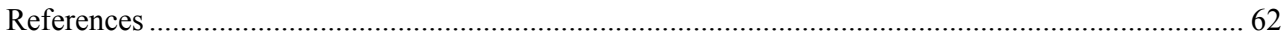




\section{Original publications}

\section{Manuscripts included in the thesis}

\section{Paper I}

Sudeep Chenna Narendra, Jaya Prakash Chalise, Mattias Magnusson \& Srinivas Uppugunduri, Local but not systemic administration of uridine prevents development of antigen-induced arthritis.

PloS One. 2015;10:e141863.

\section{Paper II}

Sudeep Chenna Narendra, Jaya Prakash Chalise, Fei Ying, Nina Almqvist and Mattias Magnusson, Dendritic cells activated by double-stranded RNA induce arthritis via type I IFN. Journal of Leucocyte Biology. 2014; 95(4):661-6.

\section{Paper III}

Jaya Prakash Chalise, Maria Teresa Pallotta, Sudeep Chenna Narendra, Björn Carlsson, Alberta Iacono, Louis Boon, Ursula Grohmann and Mattias Magnusson, IDO1 and TGF- $\beta$ mediate protective effects of IFN- $\alpha$ in antigen-induced arthritis.

Journal of Immunology 2016 Oct 15; 197(8): 3142-3151.

\section{Paper IV}

Sudeep Chenna Narendra*, Jaya Prakash Chalise*, Sophie Biggs, Louis Boon and Mattias Magnusson, Regulatory T cells manifest IFN- $\alpha$ mediated protection during antigen induced arthritis.

Manuscript

*Shared first authorship and equal contribution

\section{Relevant publications that are not included in the thesis}

Fei Ying, Jaya Prakash Chalise, Sudeep Chenna Narendra and Mattias Magnusson, (2011) Type I IFN protects against antigen-induced arthritis.

European Journal of Immunology. 41(6):1687-95.

Jaya Prakash Chalise, Sudeep Chenna Narendra, Bhesh Raj Paudyal and Mattias Magnusson, (2013) Interferon alpha inhibits antigen-specific production of pro-inflammatory cytokines and enhances antigen-specific TGF- $\beta$ production in antigen-induced arthritis. Arthritis Research \& Therapy. 15:R143. 


\section{Sammanfattning}

Människokroppens försvar mot bakterier och virus bygger bland annat på en förmåga att känna igen små strukturer hos sjukdomsalstrarna, varvid en försvarsattack, en inflammation startar som slår ut bakterierna eller virusen - och vi tillfrisknar. Ibland gör kroppen dock fel och attackerar i stället sig själv, vilket leder till inflammatorisk sjukdom. Bland dessa sjukdomar märks t.ex. typ 1 diabetes där cellerna som producerar insulin attackeras och ledgångsreumatism där lederna attackeras. Eftersom immunförsvaret attackerar den egna kroppsvävnaden kallas dessa sjukdomar autoimmuna. Mellan en halv och en procent av befolkningen lider av ledgångsreumatism, eller reumatoid artrit (RA) som sjukdomen också kallas. Behandlingen av RA har gjort betydande framsteg de senaste årtiondena men fortfarande är inte alla hjälpta och behandlingen är framförallt inriktad på en allmän dämpning av immunsystemet med biverkningar som bland annat innefattar en ökad känslighet för infektioner.

I denna avhandling studeras immunologiska processer bakom ledinflammationen och hur de kan regleras av molekylerna interferon-alfa (IFN- $\alpha$ ) och uridin. Uridin är en liten molekyl som visat sig kunna stänga av patogena immunreaktioner som liknar de som observerats vid ledgångsreumatism.

För att studera ledgångsreumatism använder vi oss av en djurmodell som liknar RA på så sätt att immunsystemets T- och B-celler attackerar leden vilket resulterar i inflammation. Modellen kallas antigen-inducerad artrit och innebär att djuren immuniseras (jmf vaccineras) två gånger med ett antigen. Då uppstår specifika T-celler och B-celler mot antigenet och de sistnämnda bildar antikroppar mot antigenet. En tid senare injiceras samma antigen i leden varpå inflammation uppstår. På detta sätt kan vi studera ledinflammationen och hur den kan behandlas.

Lokal behandling med uridin direkt i leden visade sig kunna förhindra uppkomst av ledinflammation. Systemisk behandling med uridin hade dock ingen anti-inflammatorisk effekt mot antigen-inducerad artrit. Uridin som tillförts leden minskade nivåerna av molekyler som rekryterar inflammatoriska celler till leden och minskade även produktionen av s.k. proinflammatoriska cytokiner i leden, men minskade inte systemiska nivåer av dessa cytokiner som förhöjs vid ledinflammation.

Sammanfattningsvis har uridin en tydlig lokal anti-inflammatorisk effekt som förtjänar att undersökas ytterligare.

Virusinfektioner kan ibland orsaka ledåkommor som är övergående och tidigare har det visats att RApatienter ibland har spår av viral arvsmassa i lederna. I denna avhandling visar vi på en möjlig mekanism för hur virusets arvsmassa skulle kunna orsaka ledinflammation. Virusets arvsmassa, s.k. dubbelsträngat RNA (dsRNA), aktiverar produktion av cytokinet IFN- $\alpha$ i dendritiska celler i leden, som i sin tur rekryterar andra celler som befäster inflammationen. Detta visade vi genom deponering av dsRNA direkt i musled och fann då att dendritiska celler snabbt rekryterades till leden tillsammans med andra vita blodkroppar. Därefter isolerades de dendritiska cellerna och vi fann att en förutsättning för att de skall orsaka ledinflammation är att de kan producera IFN- $\alpha$. Detta skulle alltså kunna förklara varför flera olika typer av virusinfektioner som aktiverar lokal IFN-produktion i leden kan ge upphov till ledvärk.

För att vidare studera betydelsen av viral arvsmassa och IFN- $\alpha$ för uppkomsten av ledinflammation gavs dsRNA och IFN- $\alpha$ till möss under tiden de utsätts för antigen-inducerad artrit (modell beskriven ovan). Till vår förvåning utvecklade de möss som behandlats med dsRNA eller IFN- $\alpha$ inte ledinflammation. I möss som inte kunde svara på IFN- $\alpha$ uppstod inget skydd vilket visar att IFN- $\alpha$ i sig alltså hade en skyddande förmåga mot antigen-inducerad artrit. För att skyddet skulle uppstå behövde IFN- $\alpha$ tillföras under immuniseringsfasen, medan tillförsel av IFN- $\alpha$ när artriten väl brutit ut inte gav skydd. Slutsatsen av detta är att IFN- $\alpha$ ger upphov till s.k. immunologisk tolerans som alltså medför att kroppen inte reagerar med inflammation då den stöter på ett ämne som potentiellt skulle kunna aktivera immunsystemet. 
Ett enzym som visat sig viktigt för immunologisk tolerans är indoleamine 2,3 dioxygenase (IDO) som tros vara delaktigt $i$ att motverka spontan abort, något som kan vara en form av immunreaktion. Möss som saknar IDO, eller möss vars enzymatiska IDO inhiberats, fick inget skydd av IFN- $\alpha$ mot antigeninducerad artrit. Detta visar alltså att IFN- $\alpha$ nyttjar IDO för att skyddet mot artrit skall kunna uppstå. På samma sätt visades att cytokinet TGF- $\beta$ (transforming growth factor beta) också är nödvändigt för interferonets skyddande förmåga. Då antigen-inducerad artrit, likt RA, drivs av T-celler undersökte vi effekten av IFN- $\alpha$ på just T-celler under artritutvecklingen. Ett mått på T-cellernas proinflammatoriska potential är hur mycket de delar sig då de stimuleras med antigen. T-celler från möss som behandlats med IFN- $\alpha$ delade sig mycket mindre då de stimulerades med antigenet $\mathrm{i}$ provrör. Vidare visade det sig att det var just IDO som bidrog till dämpningen av T-cellssvaret. Därefter har vi visat att aktivering av den enzymatiska aktiviteten hos IDO (som omvandlar aminosyran Tryptofan (Trp) till Kynurenine (Kyn)) är det sätt på vilket interferon skyddar mot artrit, tillika dämpar T-cellernas delning.

Studier där vi varierat tidpunkten för inhibition av IDO och TGF- $\beta$ har visat att för att interferon skall kunna skydda mot artrit, så är den enzymatiska aktiviteten hos IDO avgörande då immunsystemet kommer i kontakt med främmande antigen. Detta visades genom att inhibera IDO och TGF-beta precis i början av artritmodellens förlopp. Om inhibitionen gavs under det att artriten utvecklas, så hade det ingen effekt, dvs. IFN- $\alpha$ kunde fortfarande skydda mot artrit. Slutsatsen av detta är att interferon begagnar TGF- $\beta$ och IDO för att skapa tolerans mot ett antigen, men när väl toleransen är etablerad är det andra mekanismer än IDO och TGF- $\beta$ som förhindrar att inflammation uppstår då immunsystemet stöter på samma antigen igen.

En celltyp som är viktig för att reglera hur mycket T-celler delar sig är s.k. regulatoriska T-celler, en speciell undertyp av T-celler som tros vara viktiga för att inte inflammationer vid infektioner skall orsaka vävnadsskada. I ytterligare studier identifierade vi dessa regulatoriska T-celler (Treg) som avgörande för att interferon skall kunna skydda mot artrit. Till skillnad från IDO och TGF- $\beta$, så spelar Treg en aktiv roll i att dämpa inflammationen då artriten börjar ta form men är av mindre betydelse under immuniseringsfasen av artritmodellen.

Sammanfattningsvis tror vi att interferon kan ge upphov till tolerans på följande sätt: Då immunsystemet kommer i kontakt med IFN- $\alpha$ tillsammans med ett antigen som potentiellt kan ge upphov till inflammationsgenererande $\mathrm{T}$ - och B-celler, aktiveras ett anti-inflammatoriskt program som gör att inflammationshämmande regulatoriska T-celler bildas. I nästa steg, då en mus som behandlats med IFN- $\alpha$ vid immuniseringen med antigen utsätts för antigenet igen, aktiveras Treg som aktivt förhindrar inflammation. Kopplingen mellan aktiveringen av IDO följt av TGF- $\beta$ och aktiveringen av Treg är inte klarlagd.

Denna avhandling visar dels att uridin kan vara en möjlig lokal behandling mot ledinflammation, dels på interferonets pro-inflammatoriska egenskaper lokalt i leden och dess påtagligt anti-inflammatoriska egenskap om interferon tillförs systemiskt i samband med immunisering. Sistnämnda egenskap skulle kunna vara en framkomlig väg för att utveckla immunologisk tolerans mot oönskade kroniska inflammationer såsom autoimmunitet (t.ex. RA) och allergi. 


\begin{tabular}{|c|c|}
\hline \multicolumn{2}{|c|}{ Abbreviations } \\
\hline $1-\mathrm{MT}$ & 1-methyl DL-tryptophan \\
\hline ACPA & Anti-citrullinated protein antibody \\
\hline AIA & Antigen induced arthritis \\
\hline APC & Antigen presenting cell \\
\hline $\mathrm{CCP}$ & Cyclic citrullinated peptide \\
\hline CFA & Complete Freund's adjuvant \\
\hline CFSE & Carboxyfluorescein diacetate succinimidyl ester \\
\hline Con-A & Concanavalin A \\
\hline CTLA-4 & Cytolytic T lymphocyte-associated antigen 4 \\
\hline CIA & Collagen induced arthritis \\
\hline Cpm & Count per minute \\
\hline $\mathrm{DC}$ & Dendritic cell \\
\hline DT & Diphtheria toxin \\
\hline DMARD & Disease-modifying anti-rheumatic drug \\
\hline DMSO & Dimethyl sulfoxide \\
\hline DsRNA & Double stranded RNA \\
\hline EAE & Experimental Autoimmune Encephalomyelitis \\
\hline EDTA & Ethylene diamine tetra acetic acid \\
\hline ELISA & Enzyme linked immunosorbent assay \\
\hline FACS & Fluorescence activated cell sorting \\
\hline FBS & Fetal bovine serum \\
\hline FMO & Florescence minus one \\
\hline HES & Hypereosinophilic syndrome \\
\hline HTLV-1 & Human T-lymphotropic virus 1 \\
\hline i.a. & Intra-articular \\
\hline IBD & Inflammatory bowel diseases \\
\hline ICAM-1 & Intercellular adhesion molecule 1 \\
\hline IDO & Indoleamine 2, 3 dioxygenase \\
\hline IFN & Interferon \\
\hline IFA & Incomplete Freunds adjuvant \\
\hline Ig & Immunoglobulin \\
\hline IL & Interleukin \\
\hline i.p. & Intra-peritonial \\
\hline ISG & IFN stimulated genes \\
\hline ISRE & IFN-stimulated response element \\
\hline JAK & Janus kinase \\
\hline Kyn & Kynurenine \\
\hline LAP & Latency-associated protein \\
\hline LCMV & Lymphocytic choriomeningitis virus \\
\hline $\mathrm{LN}$ & Lymph nodes \\
\hline MACS & Magnetic-activated cell sorting \\
\hline
\end{tabular}




$\begin{array}{ll}\text { MBSA } & \text { Methylated bovine serum albumin } \\ \text { MFI } & \text { Mean fluorescence intensity } \\ \text { MHC } & \text { Major histocompatibility complex } \\ \text { MMP } & \text { Matrix metalloproteinase } \\ \text { M } \varphi & \text { Macrophage } \\ \text { MS } & \text { Multiple sclerosis } \\ \text { MTX } & \text { Methotrexate } \\ \text { NLR } & \text { NOD-like receptors } \\ \text { PAD } & \text { Peptidyl arginine deiminase } \\ \text { PBS } & \text { Phosphate buffer saline } \\ \text { pDC } & \text { Plasmocytoid dendritic cell } \\ \text { Poly I:C } & \text { Polyinosinic:polycytidylic acid } \\ \text { PRR } & \text { Pattern recognition receptors } \\ \text { RA } & \text { Rheumatoid arthritis } \\ \text { RBC } & \text { Red blood cell } \\ \text { RF } & \text { Rheumatoid factor } \\ \text { RLR } & \text { RIG-I-like receptors } \\ \text { ROS } & \text { Reactive oxygen species } \\ \text { RT } & \text { Room temperature } \\ \text { s.c. } & \text { Sub-cutaneous } \\ \text { SLE } & \text { Systemic lupus erythematous } \\ \text { STAT } & \text { Signal transducer and activator of transcription } \\ \text { TCR } & \text { T cell receptor } \\ \text { TGF- } \beta & \text { Transforming growth factor- } \beta \\ \text { Th cell } & \text { T helper cell } \\ \text { TLR } & \text { Toll-like receptor } \\ \text { TNF } & \text { Tumour necrosis factor } \\ \text { Teffectors } & \text { Effector T cells } \\ \text { Tregs } & \text { Regulatory T cells } \\ \text { Tresponders } & \text { Responder T cells } \\ \text { Trp } & \text { Tryptophan } \\ \text { TYK } & \text { Tyrosine kinase } \\ \text { WT } & \text { Wild type } \\ & \end{array}$




\section{Introduction}

\section{Rheumatoid arthritis}

Rheumatoid arthritis is a chronic autoimmune, idiopathic systemic disorder that predominantly affects women. It is characterized by proliferation of synovial fibroblasts, infiltration of inflammatory cells and release of pro-inflammatory cytokines into synovium, eventually leading to destruction of articular cartilage and bone. Apart from joints, pulmonary, cardiovascular, psychological, renal and other systems are also affected.

\section{Aetiology}

Although genetic, environmental, hormonal and infectious agents have been implicated in the aetiopathogenesis of RA, the causative mechanisms of RA are still unknown. The association of the HLA-DRB1 allele with RA suggests MHC II based self-peptide selection and presentation, and aberrant $\mathrm{T}$ cell activation as a possible part of the pathogenesis $[1,2]$. A number of infectious microbes have been linked to the aetiology of RA, although no causative agent has been identified. EBV, CMV and Proteus species have been implicated in triggering RA via molecular mimicry, formation of immune complexes and induction of proinflammatory cytokines. Many viral infections have been associated with arthralgias but no clear connection to RA has been established [3]. However, double stranded (ds) RNA, a common variant of viral RNA was detected in the synovial fluid of RA patients and correlated to a more erosive disease even though these patients had no apparent clinical viral infection [4]. Also, human T-lymphotropic virus 1 (HTLV-1) has been shown to induce arthritis quite similar to RA [5]. Another suspected microbe in the pathogenesis of RA is the bacterium Porphyromonas gingivalis. It expresses Peptidyl arginine deiminase 4 (PADI4) which is responsible for citrullination of proteins and is probably involved in breach of tolerance against citrullinated proteins, a common autoantigen in RA [6].

Smoking is one key environmental risk factor associated with RA and risk for RA increases many fold in smokers with HLA-DR4 alleles. HLA-DR alleles and exposure to smoking synergistically increase anti-citrullinated protein antibodies (ACPA) expression [7]. Exposure to smoking and silica particles triggers expression and activation of PADs via TLR stimulation. This process leads to citrullination of local proteins and formation of neoantigens. It has been shown that smoking increases PAD2 expression in the lung tissue and is associated with increased spawning of citrullinated proteins [8]. Thus, there is a possibility that the initial phase of RA begins in the lungs by triggering $\mathrm{T}$ cell mediated responses against 
the citrullinated self-peptides, probably preceded by presentation of newly formed citrullinated neo-antigens by resident lung APCs [7].

Women have a predominantly higher risk of developing RA than men with the peak incidence between 45-55 years of age [9]. Development of RA in near menopausal phase indicates association between disease onset and estrogen insufficiency/shortage. A protective role of estrogen can be noticed in pregnant RA patients where they experience spontaneous remission during pregnancy [10]. Moreover, some studies have reported a protective role of oral contraceptives containing estrogen during disease progression in RA [11-13]. The incidence rate of RA in men increases after 45 years of age and matches that of women in the same age. This can be attributed to decreased levels of androgens in both sexes. Given that androgens have a general immuno-suppressive role, the optimal production of androgens in men below 45 years of age could probably explain the lower incidence rate of RA in that age group [14]. However, no difference was noticed in androgen levels in female patients prior to onset of RA and age matched healthy controls [15].

\section{Pathogenesis of RA}

Swelling, pain, destruction of joints and disability in RA is a result of chronic inflammation in the joint synovium. The microenvironment of an inflamed RA joint is characterized by synovial proliferation, leucocyte infiltration, pannus formation and angiogenesis. Cellular compartment of an inflamed joint in RA consists of dendritic cells, macrophages, NK cells and adaptive immune cells including T cells and B cells. Apart from cells, immune complexes, complement proteins, chemokines and cytokines are also involved in the complex pathogenesis.

T cells are a component of the adaptive immune system that play a central role in initiation and maintenance of autoreactive immune responses in RA. They account for $20-50 \%$ of total cells in the inflamed synovium [16]. The established association of HLA-DR variants with the aetiopathogenesis of RA indicates repertoire of $\mathrm{T}$ cell selection and presentation of selfpeptide by APC subsequently leading to induction of autoreactive immune responses. Even though RA is likely a $\mathrm{T}$ cell dependent disease, no arthritogenic $\mathrm{T}$ cell population has been identified yet. The key role of T cells in pathogenesis of RA can be illustrated by the fact that depletion of $\mathrm{CD}^{+} \mathrm{T}$ cells in murine experimental models alleviated the disease severity and autoantibody production [17-19]. However, no apparent clinical resolution was seen after depletion of $\mathrm{CD}^{+} \mathrm{T}$ cells in the clinical trials on RA patients [20]. Depleting CD4 ${ }^{+} \mathrm{T}$ cells 
also depletes Tregs that co-express CD4 which can explain the absence of clinical resolution in RA patients. RA is principally a $T_{H} 1$ and $T_{H} 17$ cells driven disease. These cells are large contributors for synovial inflammation and joint damage [21].

On the contrary, Tregs are immunosuppressive and maintain immune tolerance. Tregs mediate suppression via secretion of TGF- $\beta$, IL-10 and via CTLA-4-interactions. Increased number of Tregs were detected in the synovium of RA patients [22]. These synovial Tregs are functional and were able to suppress effector counterparts in vitro [22, 23] but a proinflammatory milieu can hamper their suppressive capacity in the inflamed synovium. In line with this, it has been shown that a strong TCR stimulation along with CD28 co-stimulation can interfere with the suppressive capacity of Tregs [24, 25]. Moreover, resistance of effector $\mathrm{T}$ cells to Treg mediated suppression also contributes to uncontrolled $\mathrm{T}$ cell mediated immune responses. Effector T cells were more resistant to suppression by Tregs in RA patients than healthy controls. This was not due to an intrinsic defect in Tregs but due to impaired regulation of TNF-related apoptosis-inducing ligand (TRAIL) in T effector cells [26].

Dendritic cells (DCs) are APCs that initiate immune responses by presenting peptide antigens on MHC molecules. Upon antigen uptake, DCs migrate to lymphoid tissue and present the processed antigen to naïve $\mathrm{T}$ cells. They are crucial in generation and differentiation of effector T cells to mount necessary adaptive immune responses via co-stimulatory molecules, chemokines and cytokines [27].

On the other hand, DCs also play a critical role in the maintenance of central and peripheral tolerance. Under normal conditions, DCs acquire self-antigens and present them to T cells and rendering the latter anergic [28]. DCs gain tolerogenic properties by reducing co-stimulatory molecules, maintaining low to intermediate maturation, decreasing production of IL-12 and by increasing production of IDO, TGF- $\beta$ and IL-10 [28-30].

DCs are cells of innate immunity that produce large amounts of interferons (IFN) in response to viral invasion. They are mainly divided into two subclasses; myeloid derived DC (mDC) and plasmacytoid derived DC (pDC). DCs initiate and direct adaptive immune responses against the encountered pathogen. DCs also contribute to ongoing inflammation in RA by production of pro-inflammatory factors and also by regulating B cells [31, 32].

Macrophages act as APC and present antigens through MHC II molecules. Macrophages play a central role in propagation and maintenance of inflammation in RA. A greater number of macrophages can be found in the inflamed synovium of RA patients [33] and the degree of 
macrophage infiltration into the synovium corresponds directly to the degree of inflammation and joint erosion in RA [34]. Macrophages are the main TNF- $\alpha$ producing cells in the inflamed knee joint and their crucial role in maintenance of inflammation can be explained by the therapeutic potency of TNF inhibitors in RA [35]. Secretion of pro-inflammatory cytokines and chemokines by resident macrophages aids in recruitment of monocytes and neutrophils in to the synovium and induces differentiation of $\mathrm{T}$ cells, e.g., expansion of $\mathrm{T}_{\mathrm{H}} 17$ immune responses by secreting IL-23 [34]. They directly or indirectly cause erosion of the bone by their secretion of TNF- $\alpha$, IL-6 and IL-1 and subsequent activation of osteoclasts [36].

Neutrophils are the first immune cells to reach the site of inflammation and contribute to inflammation in RA by secretion of ROS, MMPs, elastase, collagenase and proteinase 3 [37]. Immune complexes including rheumatoid factor activate neutrophils by Fc $\gamma$ receptors. Neutrophils are found in large numbers in the synovial fluid and pannus of inflamed joints in RA [38]. The half-life of neutrophils is prolonged (usually $24 \mathrm{hrs}$ ) by the hypoxic conditions and anti-apoptotic factors (GM-CSF, TNF) in the inflamed synovial cavity and this is further responsible for maintenance of inflammation [37]. Recently, one study reported a novel mechanism by which neutrophils trap extracellular bacteria by releasing NETS (neutrophil extracellular traps) containing chromatin and granule enzymes [39]. This may play an important role in RA because these NETS can be a source for new citrullinated antigens. Citrullination of histone proteins by PAD4 during chromatic decondensation is a necessary process in the formation of NETS [40]. Multi-hypercitrullinated protein formation mediated by perforin and MAC activity have been found in synovial fluid neutrophils of RA patients [41]. These citrullinated proteins could be a source of neo-antigens and could be responsible for loss of tolerance. Moreover, NET formation is higher in synovial fluid neutrophils from RA patients than neutrophils from healthy controls and formation of NETS was correlated to ACPA and systemic inflammatory markers [42].

The pathogenic role of $\mathbf{B}$ cells in RA is mainly based on autoantibody production and antigen presentation to T cells. Rheumatoid factor is an autoantibody against the Fc fragment of IgG and is present in approximately $80 \%$ of RA patients [43]. Antibodies against citrullinated peptides (ACPA) are important and prominent in RA development. Therapeutic efficacy of B cell blocking drug, Rituximab in RA indicates a pathogenic role of B cells [44]. As mentioned above, genetic, smoking and other environmental factors are associated with citrullination of peptides which are implicated in triggering the development of RA. RF and ACPA antibodies can be detected in individuals long before they develop symptoms of RA 
$[45,46]$. ACPA is more specific for RA and detection of ACPA in RA corresponds to a more erosive disease course [7].

\section{Role of Cytokines}

Cytokines are small proteins secreted by cells to carry out crucial biological functions like cell growth, differentiation, proliferation, regulation of immune responses, inflammation, tissue repair and regeneration [47]. Many cytokines play an important role in the pathogenesis of RA as they drive, propagate and regulate inflammation. There is a conspicuous imbalance between pro- and anti- inflammatory cytokines [48]. TNF plays a dominant and principal role in RA as clearly shown by the efficacy of anti-TNF agents in treatment of RA. It is produced mainly by activated macrophages but is also produced by synovial fibroblasts, neutrophils and endothelial cells. Overproduction of TNF is well documented in RA and is found in high amounts in serum and in the inflamed synovium $[49,50]$. It not only activates leukocytes, synovial fibroblasts and endothelial cells but also induces proliferation and differentiation of T cells and B cells. TNF, IL-1 and IL-6 are an important triad that go hand in hand in the pathogenesis of RA. RA patients have high concentrations of these pro-inflammatory cytokines systemically and locally in the synovium $[49,51,52]$. IL-1s role in RA apart from activation of leukocytes and synovial fibroblasts includes induction of matrix-enzyme production by chondrocytes and activation of osteoclasts [1]. Anakinra, an approved IL-1 receptor antagonist has limited clinical efficacy in RA despite its therapeutic efficacy in other diseases like Gout and Muckle-Wells syndrome [53, 54]. IL-6 induces proliferation and differentiation of $\mathrm{T}$ cells and $\mathrm{B}$ cells and is involved in the production of acute-phase responses. IL- 6 is known to skew the differentiation of $T$ cells towards $T_{H} 17$ in combination with TGF- $\beta$ [55]. Over recent years, IL-17 gained a lot of importance in the pathogenesis of RA. It is reported to boost production of pro-inflammatory cytokines, MMPs, increases infiltration of immune cells into synovium and thereby sustains the inflammation in the synovium [1]. Good therapeutic effects were observed in trials with Ixekizumab and Secukizumab which are monoclonal antibodies against interleukin-17A in RA patients [5659].

Many other cytokines pro- (IL-12, IL-15, IL-18, IL-21) and anti-inflammatory cytokines (IL4 , IL-10, IL-13, TGF- $\beta$,) are also implicated in pathogenesis of RA. 


\section{Current treatment modalities in RA}

RA could be regarded as incurable disease as the aetiology is still unknown. Only transient symptomatic therapy is available for these patients. Low dose methotrexate and corticosteroids are being used as first line of treatment in RA and have clearly shown to improve outcomes of the disease [60]. Conventional disease modifying anti-rheumatic drugs (DMARDs) are effective but not all patients respond to the treatment. With the advent of biological DMARDs, disease outcome and quality of life for patients has improved vastly. The lack of reliable biomarkers has hampered development of personalized treatment strategies with biological DMARDs [61]. Further, it is yet to be determined why one particular drug is ineffective in one patient but effective in other. Nevertheless, large number of biological DMARDs have been developed during last decade and can be broadly classified into cytokine blockers, lymphocyte targeting agents (LTA) and small molecule inhibitors (SMI) of signal transduction [61]. A number of adverse effects are associated with biological DMARDs including risk of viral, fungal and bacterial infections, risk of malignancies and autoimmune syndromes. Apart from adverse effects, disadvantages also include unresponsiveness, patient selection, and high cost of treatment [62].

\section{Tolerogenic approach for treating RA}

Programming the immune system to tolerate self-peptides and educating it not to mount adequate responses in order to prevent tissue damage could be a novel therapeutic strategy to treat autoimmune diseases. This principle relies upon induction of antigen/peptide-specific immune tolerance rather than the general suppression of the immune system and maintains the ability of immune system to react to foreign antigens and infections [63]. As mentioned earlier, T cells and DCs play a principal role in pathogenesis of RA. No successful T cell or DCs targeting therapeutic molecule has been developed till now. In another perspective, $\mathrm{T}$ cells can be educated by DCs so that they do not to induce inflammation but instead maintain homeostasis. This can be achieved by production of immunoregulatory cytokines (TGF- $\beta$, IL10), altering co-stimulation (CTLA-4) and DC phenotype (tolerogenic DC), induction of Tregs and enhancing the suppressive activity of Tregs [63]. For example, Yeste et al developed a nanoparticle-based delivery of immunomodulatory molecules that induced a state of tolerance in experimental type I diabetes [64]. In this thesis, we discuss immunoregulatory and tolerogenic properties induced by IFN- $\alpha$ on Tregs and DCs in AIA. 


\section{Antigen-Induced arthritis}

Experimental animal models are being exploited to study and understand the disease mechanisms and to develop therapeutic strategies to treat diseases. Despite availability of many experimental animal models, no model can completely reproduce all pathogenic mechanisms of RA. Collagen-induced arthritis (CIA), K/BxN serum transfer and antigen induced arthritis (AIA) are the most commonly used experimental animal models for RA. AIA was developed by Dumonde and Glynn where arthritis was induced in rabbits by injecting fibrin in the knee joint [65]. AIA is a T cell driven experimental model of arthritis where arthritis is induced by intra-articular injection of antigen in pre-immunized mice. Ovalbumin, bovine serum albumin and fibrin have been used as antigen to induce arthritis in this model. Brackertz et al used mBSA as an antigen for the first time [66]. Unlike RA, in this model arthritis is confined to the antigen injected joint and the severity can be controlled locally by injected dose of the antigen [67]. Since our purpose was to study the development of tolerance against the mBSA (antigen) we have therefore utilized a model that is dependent on development of mBSA specific T cells and B cells.

Similarities to RA:

- T cells maintain and drive the chronic inflammation in the knee joint [65].

- Histopathological resemblance with immune complex deposition in cartilage, synovial infiltration, synovial membrane hyperplasia, pannus formation, bone and cartilage erosion.

- IL-1 $\beta$, IL-6 and IL-17 drive the inflammation and TNF to a minor extent [68-70].

Dissimilarities to RA:

- Arthritis specific to antigen injected joint.

- Immune responses are induced by a foreign antigen which differs from RA where there is breach of tolerance against self-peptides.

- Model is devoid of classical pathogenesis of RA, e.g. no ACPA.

\section{Type I Interferons}

Isaacs and Lindenmann discovered a factor which interfered with influenza viral replication and termed this factor as interferon in 1957 [71]. Interferons are a class of cytokines that have anti-viral and immunomodulatory properties. They are broadly classified into three families: type I IFN, type II IFN and type III IFN. Type I IFN family consists of IFN- $\alpha$, IFN- $\beta$, IFN- $\varepsilon$, 
IFN- $\kappa$, IFN- $\omega$, IFN- $\delta$ and are encoded by genes located on chromosome 9 in humans and chromosome 4 in mice. IFN- $\alpha$ is classified into 13 subtypes, IFN- $\alpha 1,-\alpha 2,-\alpha 4,-\alpha 5,-\alpha 6,-\alpha 7,-$ $\alpha 8,-\alpha 10,-\alpha 13,-\alpha 14,-\alpha 16,-\alpha 17$ and $-\alpha 21$ [72]. Type II family consists of IFN- $\gamma$ and type III family consists of IFN $\lambda 1$ (IL-29), $\lambda 2$ (IL-28A), $\lambda 3$ (IL-28B). Type I IFNs namely IFN- $\alpha$ and IFN- $\beta$ are produced by every cell type but predominantly by pDC and fibroblasts, respectively. Type I IFNs are produced in response to viral and bacterial microbes through Toll-like receptors (TLR) and TLR-independent receptors like RLRs and NLRs [73]. Type I IFN induction through TLR3 and TLR4 is dependent on signalling via the TRIF pathway while for TLR 7, 8, 9, type I IFN induction is dependent on signalling via the MYD88 pathway. Finally, downstream signalling involves activation and induction of IRFs which leads to production of type I IFNs [74]. Table 1 below describes different TLRs through which type I IFNs are induced.

\begin{tabular}{|c|c|c|}
\hline Source & Receptor & Responding cell type \\
\hline ssRNA, dsRNA & RIG-I, MDA-5 & Many cell types \\
\hline dsRNA, poly I:C & TLR3 & Macrophages and DCs \\
\hline LPS & TLR4 & Macrophages and cDCs \\
\hline ssRNA & TLR7, 8 & pDCs, cDCs, and \\
& & Macrophages \\
\hline CpG DNA & TLR9 & MDCs, cDCs, and \\
& & \\
\hline
\end{tabular}

\section{Type I IFN signalling}

Type I IFNs bind to heterodimeric receptor called IFNAR which is expressed on all cell types. This receptor consists of two subunits known as IFNAR1 and IFNAR2. IFNAR1 interacts with TYK2 whereas IFNAR2 interacts with JAK1 [72]. Activation of JAK1 and TYK2 leads to activation of the STAT family pathway. Downstream cascade includes recruitment of IRF9 and formation of STAT1-STAT2-ITF9 complex (ISGF3) which then translocates to nucleus and binds to ISREs in DNA to initiate the gene transcription. Type I IFN signalling involving STAT dependent or independent pathways include activation of PI3K-AKT, Inflammasome activation, MAPKs pathways leading to generation of diverse biological outcomes [73]. 


\section{Regulation of $\mathbf{T}$ cell responses by type I IFNs}

As mentioned earlier, type I IFNs induce an antiviral state. This includes inhibiting mechanisms involving viral replication such as shutting down translation, cell cycle arrest and inducing apoptosis in infected cells. Subsequent mechanisms include activation and regulation of innate and adaptive immune responses respectively such as promoting NK cell and CD8 T cell mediated cell toxicity, enhancing maturation of DC and antigen presentation, promoting CD4 effector cells differentiation, augmenting humoral responses [75, 76]. Type I IFNs can act directly on $\mathrm{T}$ cells for regulation of anti-viral responses depending upon timing of exposure in relation to TCR signalling [77]. It has been speculated the two opposing scenarios could take place regarding the timing of exposure in relation to TCR signalling. If TCR stimulation precedes type I IFN signalling, then proliferation, anti-apoptotic, survival and differentiation of T cells come into play. Conversely, if IFN signalling precedes TCR stimulation, anti-proliferative and apoptotic programming prevails [77]. The latter scenario is mimicked in chronic viral infections where sustained IFN signalling induces immunoregulatory DCs, T cell exhaustion and apoptosis, viral sustenance, skewed differentiation towards $\mathrm{T}_{\mathrm{FH}}$ at the detriment of $\mathrm{T}_{\mathrm{H}} 1$ cell development [77]. Murine DCs demonstrated IL-10 production and PD-L1 expression during chronic viral infection [78]. Even though the role of Type I IFN varies depending upon situation, in general Type I IFNs have incremental effect on $\mathrm{T}_{\mathrm{H}} 1$ and detrimental effect on $\mathrm{T}_{\mathrm{H}} 2$ and $\mathrm{T}_{\mathrm{H}} 17$ cells [79].

\section{Role of type I IFNs in autoimmunity}

Type I IFNs are reported to have an ambiguous role in autoimmunity. They have proinflammatory properties and a pathogenic role in SLE, Psoriasis and Sjögren syndrome whereas they exhibit a protective and therapeutic role in MS and animal models of RA, IBD and EAE $[73,80]$. In SLE, nucleic acids from apoptotic/dying cells form immune complexes with autoantibodies triggering activation of $\mathrm{pDC}$ leading to production of high amounts of type I IFNs $[73,81]$. Further, pathogenesis is complicated by activation of autoreactive T cells and plasma cells. High levels of type I IFN and higher expression of IFN genes were detected in serum of SLE patients and correlated to disease activity and severity $[82,83]$. Type I IFNs induced differentiation of monocytes into DCs further contributes to feed-back loop of IFN production. Likewise, type I IFNs play a pathogenic role in psoriasis, IFN- $\alpha$ released by pDCs triggers activation and proliferation of keratinocytes in the skin via activation of autoreactive T cells [84]. 
On the other hand, type I IFNs display a therapeutic and protective role in MS and HES [85]. IFN- $\beta$ is widely prescribed for the treatment of MS. Type I IFNs decrease the attack frequency and severity of the disease $[86,87]$. IFN- $\beta$ is reported to cut down encephalitogenic T cells by decreasing the ability of CNS APCs to present antigens [88] and also by local induction of IL-10 [89]. Type I IFNs are reported to have a therapeutic and protective effect in experimental models of IBD, however most clinical studies on ulcerative colitis and Crohn's disease have failed to prove the therapeutic efficacy of Type I IFNs [73, 90-93].

\section{Role of type I IFNs in RA and experimental models of RA}

Postulations of an infectious or viral aetiology in RA and the fact that type I IFNs are important mediators of anti-viral immunity, may suggest their involvement in RA. Type I IFNs are reported to have a controversial role in RA. Given that type I IFNs have a proinflammatory role, a number of studies have demonstrated upregulation of IFN signature genes and increased levels of type I IFNs in synovial tissue, serum and synovial fluid of RA patients [94-97]. Regardless of these findings, it is still unclear whether type I IFNs have proinflammatory or anti-inflammatory role in RA. IFN- $\beta$ is expressed in higher levels in arthroscopically extracted synovial tissue of RA patients while compared to osteoarthritis patients [98]. Further, IFN- $\beta$ treatment in RA patients reduced $\mathrm{CD}^{+}{ }^{+} \mathrm{T}$ cells, MMP-1, IL-1 $\beta$ and IL-6 in the synovial tissue extract whereas in vitro experiments with IFN- $\beta$, decreased MMP-1 and MMP-3 indicating an immunomodulatory and protective role of IFN- $\beta$ [99]. Even though treatment with IFN- $\beta$ reduced pro-inflammatory factors in the synovium of RA patients in vivo and in vitro, it failed to demonstrate therapeutic efficacy in a double blinded placebo controlled trail [100]. On the contrary, type I IFNs have been hypothesized to trigger inflammation in RA [101, 102]. Interferogenic viral dsRNA was detected in the synovial fluid of RA patients and correlated to erosive joint disease course [4]. In addition, dsRNA injected into the knee joint of mice induced arthritis which was dependent on IFNAR signalling [103]. This arthritogenic property of dsRNA was dependent on innate immunity as SCID mice which are devoid of adaptive immune cells developed arthritis upon intra-articular injection of dsRNA [104]. In line with earlier observations, we have shown that dsRNA stimulated DCs induced arthritis dependent on IFNAR signalling when injected into knee joints of mice. A study demonstrated an association between IFN genes signature and progression of arthritis in RA patients [105]. Further, type I IFN gene signature was recommended as an early prognostic marker for the prediction of arthritis in RA patients [106]. Type I IFNs are known 
to promote autoantibody formation [107] and in one case report, pegylated interferon- $\alpha 2 \mathrm{a}$ induced anti-CCP positive RA in a chronic case of HCV infection [108].

In the majority of scientific reports, type I IFNs have been shown to have anti-inflammatory properties in experimental models of arthritis. Treatment with recombinant IFN- $\beta$ or IFN- $\beta$ producing fibroblasts ameliorated CIA in mice [109, 110]. Our group previously showed that treatment with dsRNA or IFN- $\alpha$ during development of antigen-specific adaptive immune response clearly protected mice against AIA [111]. Similarly, a high dose treatment regimen with dsRNA or IFN- $\alpha$ during effector phase of collagen antibody-induced arthritis, suppressed arthritis in IFNAR dependent manner. The possible mechanisms behind anti-inflammatory properties of type I IFNs include, but are not limited to; inhibition of TNF, IL-6, IL-1 $\beta$, IL-17 and osteoclasts $[109,112]$ and boosting production of IDO and TGF- $\beta$ [113]. In summary, IFN- $\alpha$ may have diametrically opposed effects on arthritis dependent on whether it is a direct, innate effect in the joint or an effect on adaptive immune responses.

\section{Regulatory $\mathbf{T}$ cells}

Tregs play a crucial role in maintenance of central and peripheral tolerance and immune homeostasis. Dysfunction in the suppressive capacity of Tregs could lead to uncontrolled immune reactions, autoimmune diseases and allergy [114]. These cells can be broadly classified into two types based on the origin of development; natural occurring thymic derived Tregs and induced Tregs. These two subsets are further classified into FOXP ${ }^{+}$Tregs $\left(\mathrm{CD} 4^{+} \mathrm{CD} 25^{\mathrm{hi}}\right), \operatorname{Tr} 1$ and Th3 cells. Tr1 and Th3 cells develop from conventional T cells and act as secondary suppressor cells by their ability to secrete IL-10 and TGF- $\beta$ respectively [115]. $\mathrm{FOXP}^{+}$Tregs have an ability to suppress activation, proliferation and cytokine production of many immune cells including effector T cells, APC and B cells. These cells were first described in mice by Sakaguchi group and they constitutively express CD4 and IL2 receptor called CD25 [116]. The FOXP3 gene was shown to play a central role in the development and suppressive function of $\mathrm{FOXP}^{+}$Tregs, based on studies on scurfy mice. These mice lack functional FOXP3 gene and develop a fatal, lymphoproliferative disorder [117]. Expression of markers like CD25, CTLA-4 and GITR confers suppressive capacity of naïve $\mathrm{CD}^{+} \mathrm{T}$ cells that acquire ectopic expression of FOXP3 [115]. Tregs express their suppressive activity by many mechanisms of which some are listed below:

1. Cell-cell contact dependent: Tregs suppress targets cells via direct receptor-ligand interactions. CTLA-4 on Tregs interacts with B7 (CD80 \& CD86) on APC and down 
modulates co-stimulation of effector T cells by inhibiting CD28-B7 interaction. Other mechanisms include suppression of T cells via membrane-bound TGF $\beta$ and inhibition of DC maturation via LAG3 $[118,119]$.

2. Cell-cell contact independent: Tregs have ability to suppress other immune cells by secretion of TGF- $\beta$, IL-10 and IL-35 [118]. Tregs are known to stimulate production of the immunosuppressive enzyme, indoleamine 2,3 dioxygenase (IDO1) in APC via CTLA-4/B7 interaction [120]. Further, Tregs utilize IL-2 competitively which is essential for proliferation of effector T cells [121] thereby causing apoptosis in these cells [122].

\section{Effect of type I IFNs on Tregs}

Type I IFNs have divergent and paradoxical effects on Tregs depending upon disease and experimental conditions [123]. Type I IFNs were reported to upregulate the Tregs numbers and suppressive capacity and promote FOXP3 mRNA expression in MS, Chronic Hepatitis C infection, experimental models of colitis and encephalomyelitis [124-129]. Inducers of type I IFNs or type I IFNs were shown to induce IDO1 which regulates immune tolerance by promoting generation and augmenting the suppressive capacity of Tregs [130-132]. Conversely, IFN- $\beta$ was shown to directly inhibit Tregs during acute LCMV infection which was essential to mount an adequate anti-viral responses in the initial phase of the infection [133]. Likewise, type I IFNs down modulated development of Tregs in an IL-2 dependent manner [134].

\section{TGF- $\beta$}

Transforming growth factor beta is large family of cytokines with pleiotropic properties. The TGF- $\beta$ family consists of TGF- $\beta 1$, TGF- $\beta 2$, and TGF- $\beta 3$ which are produced by a variety of cells including fibroblasts, platelets, mast cells, monocytes, macrophages, and Tregs [135]. Inactive form of TGF- $\beta$ is one big complex containing dimers of TGF- $\beta$ associated with latency-associated protein (LAP). Cleavage or disruption of non-covalent links between LAP and TGF- $\beta$, releases the active form of TGF- $\beta$ [136]. TGF- $\beta$ binds to the TGF- $\beta$ receptor complex (TGF- $\beta$ RI and TGF- $\beta$ RII) and triggers a cascade of signalling through recruitment of SMAD proteins

Development of severe and fatal inflammatory disease in mice lacking a functional TGF- $\beta$ gene indicates the principal role of TGF- $\beta$ in maintenance of immune regulation $[137,138]$. It exerts its immunoregulatory effects on all kinds of cells including $\mathrm{T}_{\mathrm{H}} 1, \mathrm{~T}_{\mathrm{H}} 2$, DCs, 
macrophages, B cells and neutrophils [139]. TGF- $\beta$ affects proliferation and differentiation of T cells and the ability of TGF- $\beta$ to suppress T cell proliferation via inhibition of IL-2 and by affecting cell cycle regulators [140-142]. TGF- $\beta$ inhibits differentiation of $\mathrm{T}_{\mathrm{H}} 1$ cells by downregulating expression of the IL-12 receptor and T-bet expression, and it also inhibits differentiation of $\mathrm{T}_{\mathrm{H}} 2$ cells by suppressing expression of GATA-3 [143]. TGF- $\beta$ plays a major role in the development and maintenance of peripheral Tregs though its role on development of thymic Tregs is limited [144]. Indeed, TGF- $\beta$ increases FOXP3 expression on Tregs thereby increasing their suppressive capacity $[145,146]$. On the other hand, TGF- $\beta$ skews differentiation of naïve $T$ cells towards $T_{H} 17$ in the presence of IL-6 [147].

Many reports describe the role of TGF- $\beta$ in the pathogenesis of various autoimmune diseases. Decreased expression of TGF- $\beta$ was found in SLE patients [148]. However, decreased expression of TGF- $\beta$ did not correspond to disease severity [149]. Moreover, IDO knockout mice or mice containing non-functional TGF- $\beta$ gene develop pathogenic features matching SLE, including formation of autoantibodies against dsDNA and ssDNA, IgG deposits in glomeruli of kidneys $[138,150]$. The role of TGF- $\beta$ in RA is controversial, given the fact that systemic administration of TGF- $\beta$ down modulates CIA [151] whereas local administration of TGF- $\beta$ aggravates arthritis [152]. Systemic administration of TGF- $\beta$ prevented EAE in mice and blocking TGF- $\beta$ with neutralizing antibodies magnified the disease severity of EAE [153155]. The protective properties of TGF- $\beta$ in various experimental models of autoimmunity are due to the ability of TGF- $\beta$ to induce FOXP3 Tregs, suppress $\mathrm{T}_{\mathrm{H}} 17$ cells, and also by induction of IDO1 [156].

\section{IDO}

Indoleamine 2, 3-dioxygenase (IDO or IDO1) is a catabolic enzyme responsible for the breakdown of tryptophan to kynurenine (KYN) [157]. IDO1 is coded by the ido1 gene located on chromosome 8p12 in humans and chromosome 8A2 in mice [158]. A similar catabolic enzyme, IDO2 was reported in mammals [159] and is encoded by the IDO2 gene located on chromosome 8P21 in humans. The biological role of IDO2 is yet to be explored but its role in maintenance of immune tolerance is minimal compared to IDO1 [160].

IDO1 is expressed in various tissues by DCs, monocytes and macrophages. Its expression is induced by interferons (type I, II), interferon inducing substances such as virus, CpG DNA and LPS and certain cytokines such as TNF, TGF- $\beta$ and IL-10 [156, 161-163]. The promoter region of IDO genes contain ISRE and GAS elements indicating IDO1 expression is regulated by type I and II IFNs [164]. IDO1 is also induced in DCs by CTLA-4 expressing T cells by 
interacting with B7 molecules on DCs which is an important mechanism in the maintenance of peripheral tolerance $[29,165]$.

\section{Modulation of immune system by IDO1}

The immunomodulatory role of IDO1 was noticed when pregnant mice treated with the IDO1 inhibitor 1-MT (1-methyl tryptophan), resulted in spontaneous rejection of allogenic fetus [166]. This discovery indicated the importance of IDO1 in the maintenance of immune tolerance at maternal-fetal interface. IDO1 acts as a general immune regulator and limits proinflammatory conditions in response to inflammatory stimuli. However, IDO1 is not vital for regulation of self-tolerance as IDO1 knock out mice $\left(\right.$ IDO $\left.^{--}\right)$do not die from autoimmune responses [167].

IDO1 regulates immune responses in a number of ways; by exhaustion of the essential amino acid tryptophan leading to apoptosis and inhibition of $\mathrm{T}$ cell proliferation $[29,168]$ and by generation of enzymatic end products, like KYN, that can be toxic for T cells and also suppress T cell proliferation $[169,170]$. Many studies also report that IDO1 stimulates induction of Tregs $[29,165,171]$ which is thus an indirect way by which IDO1 regulates T cell proliferation. Naïve T cells treated with the IDO-metabolite KYN acquire a regulatory phenotype by induction of FOXP3 via TGF $\beta$ [131, 172]. Another mechnism by which KYN promotes generation of Tregs is by interaction with the aryl hydrocarbon receptor (AhR) expressed on T-cells $[173,174]$. IDO1 may also indirectly promote Treg development via DCs. e.g. a subset of DCs expressing CD19 ${ }^{+}$suppress T cells by expression of IDO1 in response to TLR9 signalling which is activated by CTLA-4 ligation on DCs [175]. IDO1 may also induce production of TGF- $\beta$ expression in DC, which is a known activator of Tregs[113, $176,177]$.

Recently, a novel non-enzymatic immunoregulatory mechanism of IDO1 was reported. A stable immunoregulatory phenotype of pDCs was generated by an intracellular signalling pathway of IDO1 that was dependent on TGF- $\beta$, but not relying on the enzymatic function of IDO1 [156]. TGF- $\beta$ phosphorylated inhibitory tyrosine based motif $1 \& 2$ (ITIM) of IDO1 in pDCs which then bound to tyrosine protein phosphatases SHP-1 and SHP-2 activating a downstream signalling of non-canonical NFKB. Further, phosphorylation of IDO1 activates signalling through non-canonical NFKB and SHP proteins leading to sustained production of TGF- $\beta$ and type I IFNs which collectively renders long term tolerance through induction of regulatory pDC phenotype [156]. 
The Role of IDO1 in autoimmune diseases is yet to be studied. Reports from many experimental models of human diseases indicate tolerogenic and protective role of IDO1 [178-181]. Inhibition of IDO1 by 1-MT exacerbates CIA or EAE in mice [130, 182, 183]. One study has shown that, IDO1 is expressed in higher amounts in RA patients while compared to controls and was inversely correlated with disease severity and inflammation [184].

\section{Uridine}

Uridine is a natural metabolite that is present in all living cells. It is a pyrimidine nucleoside required for synthesis of RNA, glycogen, bio-membranes and hence, essential for cellular growth, function and metabolism [185]. In humans, uridine is present in plasma, cerebrospinal fluid and seminal fluid and its concentration varies from 3-8 $\mu \mathrm{M}$ in the body $[185,186]$. Uridine is rapidly metabolized by the liver and has a very short half-life in vivo. Sugar cane, tomatoes, broccoli and beer are rich in uridine. However, due to low bioavailability and rapid metabolism of uridine, the body depends upon pyrimidine salvage for uridine retrieval [186].

Uridine and its analogues are also known to act as extra-cellular signalling molecules through G-coupled, P2Y receptors. These receptors are present on various cells and organs in the human body. Activation of these receptors leads to activation of phospholipase C (PLC), protein kinase $\mathrm{C}(\mathrm{PKC})$, mitogen-activated protein kinase (MAPK) and mobilization of calcium ions $(\mathrm{Ca} 2+)$ [186].

Recently, uridine has been shown to have many therapeutic properties. Uridine is reported to have neuroprotective effects in hypoxic-ischemic encephalopathy [187], anti-convulsant effects [188] and protective effects in a dry eye model [189] . Moreover, uridine gained popularity for its protective outcome on 5-fluorouracil [190], fenofibrate [191], nucleoside analogue reverse transcriptase inhibitors (NRTIs) [192, 193], tamoxifen [194]induced adverse effects. Further, local administration of uridine has been shown to inhibit inflammation by decreasing leucocyte migration and TNF and IL-6 secretion in an animal model of acute lung inflammation [195-197]. Also, uridine suppressed the classical features of asthmatic airway inflammation suggesting that uridine could be a potential therapeutic agent for treatment of asthma [197]. 


\section{Aims}

The main aim of this thesis is to increase our understanding how uridine, IFN- $\alpha$ and dendritic cells regulate experimental arthritis locally or systemically.

\section{Specific aims}

Paper I: To study the effect of uridine on mBSA-induced arthritis.

Paper II: To determine the occurrence of different DC populations in dsRNA-induced arthritis and their ability to mediate dsRNA-induced arthritis and if this ability is dependent on type I IFN signalling.

Paper III: To analyse the role of IDO1 and TGF- $\beta$ in IFN- $\alpha$ mediated protection against AIA.

Paper IV: To study the role of regulatory T cells in IFN- $\alpha$ mediated protection against AIA. 


\section{Experimental design and methods}

\section{Mice}

SV129EV, IFNAR KO and NMRI mice were bought from B \&K Universal. IDO1 ${ }^{-/}$, LysM $\mathrm{Cre}^{+}, \mathrm{Tg} f b \mathrm{f}^{f l f l}$ and Foxp3DTReGFP mice were bought from Jackson Laboratories, Maine, USA. Some strains of mice were further in-bred at the animal facility, Linköping University. For both IDO1 ${ }^{-/-}$and Foxp3DTReGFP strains, heterozygous breeding pairs were bred, which generated wild type (wt, IDO ${ }^{+/+}$), heterozygous (ht, $\mathrm{IDO}^{+/-}$), and homozygous progeny (mutated gene in both alleles, $\mathrm{IDO}^{-/}$). The DNA from ear tissue was used to identify homozygous and wild type progeny according to the protocol for genotyping from Jackson laboratories. Wild type mice were used as controls for the experiments. $\mathrm{LysM} \mathrm{Cre}^{+}$and $T g f b 1^{f l / f l}$ were crossbred to generate $L y s M C r e^{+/-} T g f b r 21^{f l / f l}$. CD4-Cre ${ }^{+/-}$Ifnar ${ }^{f l / f l}$ and CD4-Cre Ifnar $^{f l f l}$ mice were provided on a collaborative basis by Professor Ulrich Kalinke (Centre for Experimental and Clinical Infection Research, Twincore, Hannover, Germany).

All animals were housed at the animal facility, Linköping University and were kept under standard conditions. All experimental procedures were performed according to the guidelines provided by The Swedish Animal Welfare Act and were approved by Ethical Committee Board, Linköping University (Dnr.77-09, 66-10, 1-12) and South Stockholm regional court (N-271/14).

For experiments conducted at Göteborg University, SV129EV and IFNAR KO were a gift from Maries van den Broek (Zurich University, Switzerland). All experimental procedures were performed according to guidelines provided by The Swedish Animal Welfare Act and were approved by Ethical Committee Board, Göteborg University (Dnr.313-2004 and 1762008).

\section{Induction of mBSA-induced arthritis (Paper I, III \& IV)}

Mice were immunized at day 1 subcutaneously in the left flank with $200 \mu \mathrm{g}$ of mBSA (Sigma-Aldrich, Stockholm, Sweden) (final conc. $1 \mu \mathrm{g} / \mu \mathrm{l}$ ) emulsified with freunds incomplete adjuvant (FIA) and phosphate buffered saline (PBS). At Day 7, mice were booster immunized subcutaneously at the base of the tail $(50 \mu \mathrm{l}$ on each side) with $100 \mu \mathrm{g}$ of mBSA emulsion (prepared as mentioned above). In brief, mBSA was added to equal volumes of PBS and FIA (1:1) and this mixture was rigorously mixed using two syringes connected to a 3-way stopcock until a white, thick emulsion is formed. For arthritis induction, $30 \mu \mathrm{g}$ of mBSA (in 
$20 \mu 1$ of PBS) was injected in the left knee joints and for control, $20 \mu 1$ of PBS was injected into right knee joints of the mice (Fig. 1).

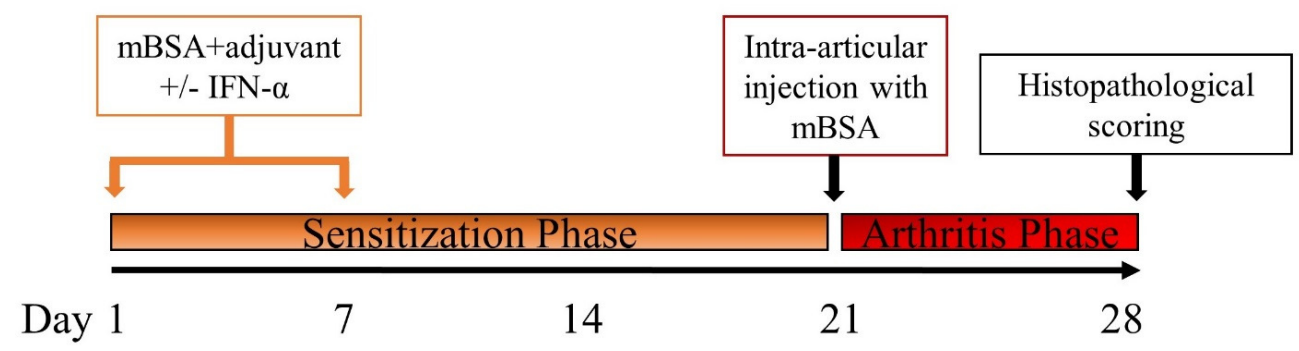

Figure1: Schematic depiction of mBSA-induced arthritis (AIA) model.

\section{Administration of IFN- $\alpha$ (Paper III, IV)}

IFN- $\alpha$ A was administered at day 1 and 7 of mBSA-induced arthritis as depicted in figure 1 . $1000 \mathrm{U}$ of recombinant murine IFN- $\alpha$ A (PBL Assay Science, Piscataway, USA) was added to the antigen mixture (mBSA+PBS+FIA) during emulsion preparation and was administered on day 1 and day 7.

\section{Uridine treatment protocol (Paper I)}

For systemic administration, $0-100 \mathrm{mg} / \mathrm{kg}$ of uridine was administered s.c. on day 1, 7, 14 (i.p.), 21 and 23 during AIA. In another series of experiments, uridine pellets (that release $0.75 \mathrm{mg}$ or $1.5 \mathrm{mg}$ of uridine per day during 29 days) were surgically inserted s.c. in the dorsal neck region. For local administration of uridine, a single dose of 0-100 mg/kg of uridine was co-administered intra-articularly in right knee joint along with mBSA (that induce arthritis) on day 21 .

\section{Other treatment protocols (Paper III)}

For 1-MT drinking water solution, DL 1-Methyltryptophan (1-MT) (Sigma-Aldrich) was dissolved in $0.05 \mathrm{M} \mathrm{NaOH}$ and adjusted to $5 \mathrm{mg} / \mathrm{ml}$ with distilled water and $\mathrm{pH}$ to $9.0 \mathrm{using}$ $\mathrm{HCL}$ or $\mathrm{NaOH}$. Freshly prepared 1-MT drinking water solution was refilled every three days during treatment. Control mice received drinking water with $\mathrm{pH}$ adjusted to 9.0. Each mouse consumed 2-2.5 ml (10-12.5 mg of 1-MT/day) of the solution on average every day. For blocking TGF- $\beta, 150 \mu \mathrm{g}$ (in $200 \mu 1$ of PBS) of anti-TGF- $\beta$ antibodies (clone 1D11, reactive to TGF- $\beta 1 / \beta 3$ ) (EPIRUS Biopharmaceuticals Netherlands BV) were injected i.p. daily in the 
mice for indicated time. Control mice received $200 \mu 1$ of PBS i.p.

pDCs were depleted using daily administration of $150 \mu \mathrm{g}$ of $120 \mathrm{G} 8$ clone (Dendritics, Lyon, France) for indicated time. Control mice received $200 \mu$ of PBS i.p.

\section{dsRNA induced arthritis (Paper II)}

dsRNA was extracted from MA104 cell line of fetal rhesus monkey kidney cells infected with Rota virus as described earlier [4, 104]. $5 \mu \mathrm{g}$ of dsRNA was mixed with in vivo transfection agent JetPEI (Qbiogene, Illkirch, France) and was administered intra-articularly in a total volume of $20 \mu$ l. For negative controls, PBS alone was administered intra-articularly. Three days post intra-articular injection, joints were evaluated as described below.

\section{Histopathological scoring of arthritis}

Mice were sacrificed on day 28 and knee joints were isolated and fixed in $4 \%$ buffered formaldehyde (Histolab AB, Sweden) for 7-10 days. The joints were then decalcified using a mixture of formic acid and sodium bicarbonate (Sigma-Aldrich, Stockholm, Sweden) for 3 days. Further, knee joints were dehydrated and embedded in paraffin for sectioning. $5 \mu \mathrm{m}$ sagittal tissue sections of knee joints were prepared and stained with hematoxylin-eosin (Histolab AB, Göteborg, Sweden) Arthritis severity was measured on an arbitrary scale (0-3) by at least two independent researchers in a double blinded manner. Arthritis was scored based on microscopic pathological changes such as synovial thickening, synovial infiltration and bone erosion (Fig. 2). 0-normal joint, 1- mild inflammation, 2-moderate inflammation and 3 -severe inflammation. A score $\geq 1$ was considered as arthritic knee joint.

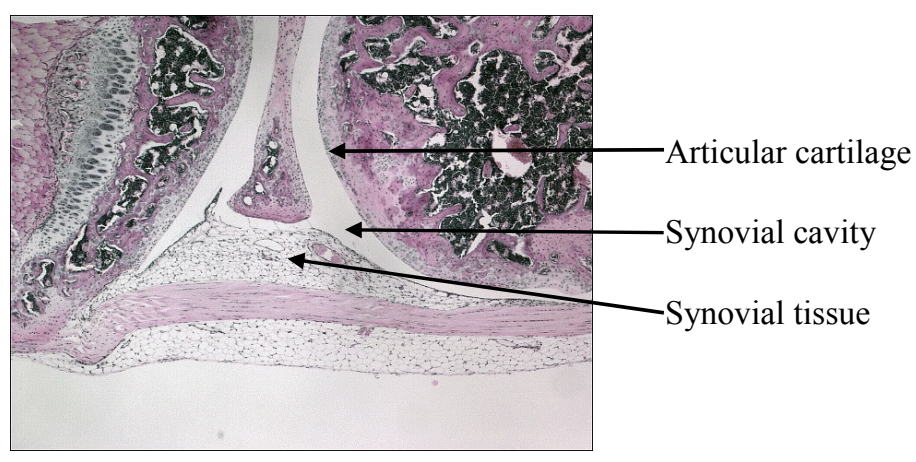

Normal knee joint (score $=0$ ) 


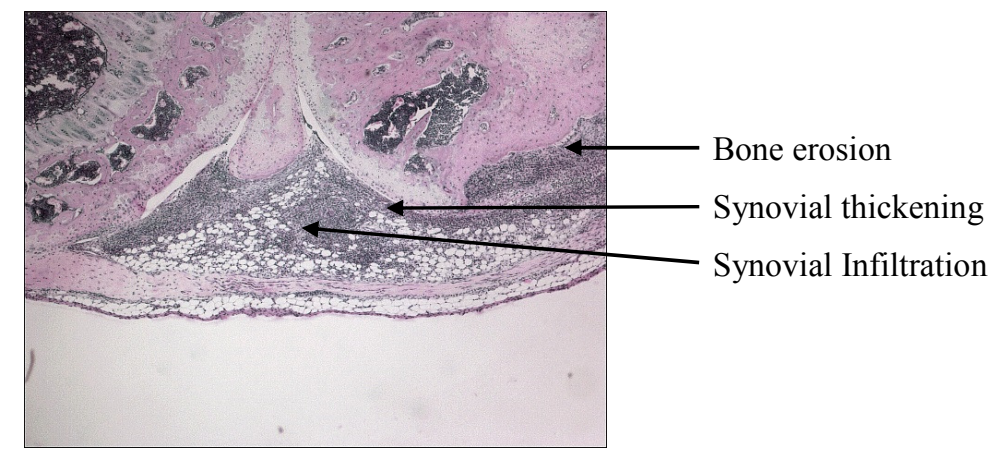

Arthritic knee joint (score $=0)$

Figure 2: Representative histopathological slides of knee joint (magnification 4X) isolated at day 28 of AIA describing the parameters used for evaluation of arthritis severity.

\section{Immunohistochemistry (IHC) and scoring (Paper I, II)}

Fixed tissue sections were de-paraffinised with xylene and were then rehydrated with decreasing strengths of alcohol $(99 \% \rightarrow 95 \% \rightarrow 70 \% \rightarrow$ distill water). Tissue sections were immersed in sodium citrate buffer $(\mathrm{pH}=6.0)$ and were heated for 20 minutes in oven for antigen retrieval. Tissue sections were blocked with diluted goat serum (5\%) for 20 minutes followed by washing with PBS-Tween 20. For detection of intracellular cytokines, sections were incubated in $0.3 \%$ triton for 10 minutes prior to blocking. Sections were incubated with primary rabbit antibodies directed against murine TNF (ab9739-ABCAM, Cambridge, UK), IL-6 (BS-0379R- Bioss Inc., Massachusetts, USA), CD3 ( BS-4815R- Bioss Inc.), F4/80 (sc26643-R- Santa Cruz Biotechnology, Inc., Dallas, USA), neutrophil elastase (ab68672ABCAM), ICAM-1 (BS-0608R- Bioss Inc.), CD18 (LFA-1) (BS-0503R- Bioss Inc.) and isotype control rabbit IgG ( bs-0295p-Bioss Inc.). Bound primary antibodies were detected using IHC detection kit (ab64261-ABCAM) according to the manufacturer's instructions. Following development with 3, 3'-Diaminobenzidine (DAB), sections were counterstained with Mayers haematoxylin (Histolab AB, Göteborg, Sweden).

An arbitrary scale from 0-5 based on intensity and extensiveness of staining was used to perform IHC scoring of knee sections [198, 199]. A score of 0 represented no expression and 5 represented abundant expression. 
For detection of DCs in dsRNA-induced arthritis, three days post-injection of dsRNA, knee joints were decalcified and were embedded in Tissue-Tek. Tissue was cryosectioned and stained with primary rat antibodies against mouse CD11c, MHC class II, 120G8 (Dendritics, Dardilly, France) and isotype control. Positive cells were detected with alkaline phosphataseconjugated rabbit anti-rat IgG (Dako, Stockholm, Sweden). Sections were then developed using liquid permanent red (Dako) as counter stained with haematoxylin as per manufacturer's instructions.

\section{Generation of DCs (Paper II)}

Femur and tibia were isolated and were stripped of all muscles and connective tissue in aseptic conditions. Metaphysis part of bones were cut and bone marrow was extracted by flushing complete medium into the bone cavity. Red blood cells in bone marrow were then lysed using lysis buffer (Sigma-Aldrich). After subsequent washing, cells were seeded in the culture plate at 1 million cells $/ \mathrm{ml}$ and incubated with medium containing $25 \mathrm{ng} / \mathrm{ml}$ of murine Flt3L (R\&D Systems, Minneapolis, MN, USA) for 9 days at $37{ }^{\circ} \mathrm{C}$ in $5 \% \mathrm{CO}_{2}$ and $95 \%$ humidity. Half of the medium was replaced with freshly prepared medium containing Flt3L on days 3 and 6 . Cells were harvested on day 9.

DC activation: DCs $\left(10^{5}\right.$ cells in $\left.200 \mu \mathrm{l}\right)$ were stimulated with $150 \mu \mathrm{g} / \mathrm{ml}$ of dsRNA (poly I:C; Sigma-Aldrich, St.Louis, MO, USA) or $10 \mu \mathrm{g} / \mathrm{ml}$ of dsRNA from Rota virus or UVinactivated HSV (4x10 $\mathrm{PFU} / \mathrm{ml}$; gift from Kristina Eriksson, Göteborg University) or medium alone for 24 hours at $37^{\circ} \mathrm{C}$ in $5 \% \mathrm{CO}_{2}$ and $95 \%$ humidity.

\section{DC injection protocol (Paper II)}

Flt3L derived bone marrow DCs , $\mathrm{cDC}\left(\mathrm{CD} 11 \mathrm{c}^{+} \mathrm{PDCA}^{-1^{-}}\right)$and $\mathrm{pDC}\left(\mathrm{CD} 11 \mathrm{c}^{+} \mathrm{PDCA}-1^{+}\right)$ sorted from spleens or Flt3L derived bone marrow DCs, non-DC cell population (CD11 ${ }^{-}$ PDCA- $1^{-}$) were stimulated as described above for 4 hours and were washed three times in PBS. 80,000 cells in $20 \mu 1$ of PBS were injected intra-articularly to the healthy knee joint. For contralateral knee joint, either vehicle alone, non-DC alone or dsRNA stimulated non-DC cell population were injected similarly.

\section{FACS analysis and sorting of DCs (paper II)}

Flt3L dervied DCs and single cell suspension of splenocytes were analyzed by FACS. Flt3L dervied DCs were sorted into cDC (CD11 $\mathrm{c}^{+}$PDCA-1- $)$, pDC (CD11 $\mathrm{c}^{+}$PDCA-1 $\left.{ }^{+}\right)$and nonDC cell population (CD11c- PDCA-1 ${ }^{-}$) using CD11c PE (BD, San Diego, CA, USA) and 
biotinylated PDCA-1+streptavidin-allophycocyanin (Miltenyi Biotech, Germany) or mPDCA-1 (CD319) APC (Ebioscience) by Gallios and ARIA-III sorter.

\section{Quantification of Tregs in blood, spleens and LNs (Paper IV)}

Blood was collected from the tails of the mice at day 0, 4, 10, 14, 20, 24 and 28 during AIA in heparin containing Eppendorf tubes. $100 \mu 1$ of heparinized blood was surface stained with rat anti-mouse CD4 FITC antibody (BD Biosciences, San Jose, CA, USA) and rat anti-mouse CD25 PE antibodies (eBioscience, San Diego, CA, USA) followed by fixation and permeabilization with Foxp3 staining set (eBioscience, USA) according to the manufacturer's instructions. For intra-cellular staining, cells were stained with rat anti-mouse Foxp3 APC (eBioscience, USA) and analysed with FACS Gallios (Beckman Coulter, Inc., Brea, United States) and collected data were analysed with Kaluza ${ }^{\circledR}$ flow analysis software, Beckman Coulter (version 1.5). The percentages of Foxp $3^{+}$Tregs among gated $\mathrm{CD} 4^{+}$cells were determined by FMO gating as earlier described [200].

\section{Ex Vivo assessment of antigen-specific proliferation (Paper I, III)}

At day 28 of AIA, spleens and draining lymph nodes were isolated and passed through a $70 \mu \mathrm{m}$ nylon cell strainer to make a single cell suspension. RBCs were lysed as described in above section. 200,000 cells were seeded per well in triplicates in a 96-well plate using Iscoves Modified Dulbecco's Medium (Sigma-Aldrich) supplemented with $10 \%$ fetal bovine serum (Sigma-Aldrich), 4mM glutamine (Sigma-Aldrich), $50 \mu \mathrm{M} \beta$-mercaptoethanol (SigmaAldrich), $100 \mathrm{U} / \mathrm{ml}$ of penicillin and $0.1 \mathrm{mg} / \mathrm{ml}$ of streptomycin (Sigma-Aldrich) and restimulated with $50 \mu \mathrm{g} / \mathrm{ml}$ of mBSA or Concavalin A $(1 \mu \mathrm{g} / \mathrm{ml})$ or anti-CD3 antibody (1 $\mu \mathrm{g} / \mathrm{ml}$ ) for 48 hours. ${ }^{3} \mathrm{H}$-thymidine (final conc. $0.5 \mu \mathrm{ci}$ ) was added to wells and cells were incubated for an additional 20 hours. In this method, radioactive thymidine gets imbibed into new chromosomal strands of DNA in dividing cells. The extent of cell division is directly proportional to amount of radioactivity (measured as counts per minute cpm). The radioactivity is measured by scintillation beta-counter. The cell proliferation was expressed as mean cpm \pm SEM value.

\section{Blood sampling}

Blood was collected from mice at various time points of AIA. Mice were sedated using isoflurane inhalation and a small incision was given using a scalpel at ventral side of base of the tail. Around 100-200 $\mu 1$ of blood was collected in eppendorf tubes and was kept at room temperatures for 1-2 hours. Blood was centrifuged at 5000G and then serum was separated 
and stored at $-20 \mathrm{C}$ for further analysis.

For FACS analysis, blood was collected in Eppendorf tubes containing $50 \mu 1$ of heparin.

\section{ELISA for quantification of anti-mBSA specific IgG (paper I)}

Enzyme Linked Immunosorbent Assay (ELISA) was used to quantify anti-mBSA specific total IgG. 96-well flat bottomed ELISA plates (Nunc, Thermoscientific) were coated with mBSA $(10 \mu \mathrm{g} / \mathrm{ml})$ diluted in $50 \mathrm{mM}$ bicarbonate/carbonate buffer overnight at $4{ }^{\circ} \mathrm{C}$. The coated wells were blocked with $200 \mu 1$ of $2 \%$ casein (Sigma-Aldrich) for 2 hours at room temperature (RT). Serum samples were diluted 1:500 in casein buffer and $100 \mu 1$ of diluted samples were added in triplicates and incubated for 2 hours at RT. $100 \mu 1$ of horseradish peroxidase (HRP)-conjugated secondary antibody (Southern Biotech, Birmingham, AL, USA) diluted 1:4000 was added to the wells and plates were incubated for 2 hours at RT. Between each step, plates were washed 3 times with PBS containing 0.05\% Tween-20. The plates were developed by adding $100 \mu 1$ of 3,3',5,5'-tetramethylbenzidine (TMB) (Sigma) substrate solution followed by incubation in darkness for 20 minutes. Finally, the reaction was stopped by adding $50 \mu \mathrm{l}$ of $1 \mathrm{M} \mathrm{H}_{2} \mathrm{SO}_{4}$ and the developed colour was quantified at $450 \mathrm{~nm}$ by an ELISA reader (Versa Max Microplate Reader).

\section{ELISA for quantification of TGF- $\beta$ (Paper III)}

TGF- $\beta 1$ levels in the serum collected at various time points of AIA and in supernatants from ex vivo stimulated splenocytes was quantified using a readymade ELISA kit (Ebioscience). 96 well Nunc plates were coated with capturing antibody diluted in coating buffer and incubated overnight at $4{ }^{\circ} \mathrm{C}$. Coated wells were blocked by adding assay diluent for 1 hour at RT. To activate latent TGF- $\beta 1,1 \mathrm{~N}$ HCL was added to the samples and incubated for 10 minutes at RT followed by neutralization with addition of $1 \mathrm{~N} \mathrm{NaOH}$. Serum samples were diluted 1:100 whereas supernatants were diluted 1:4. Standards of TGF- $\beta 1(8-1000 \mathrm{pg} / \mathrm{ml})$ were prepared according to manufacturer's instructions. Standards and samples were added to the plate and incubated overnight at $4{ }^{\circ} \mathrm{C}$. After adding detection antibody, plates were incubated for 1 hour at RT followed by addition of Avidin-horseradish peroxidase. Between each step, wells were washed six times with PBS containing 0.05\% Tween-20. Plates were then developed by addition of TMB substrate solution and the reaction was stopped with $1 \mathrm{~N} \mathrm{H}_{2} \mathrm{SO}_{4}$ after 10 minutes. Colour developed was measured by an ELISA reader at $450 \mathrm{~nm}$. The concentrations were quantified by using a four parameter logistic regression standard curve. 


\section{ELISA for IFN- $\alpha$ (paper II)}

IFN- $\alpha$ levels in supernatant were determined by a homemade kit. In brief, 96 well Nunc plates were coated with sheep anti-mouse IFN- $\alpha$ diluted 1:2000 in PBS and incubated overnight at 4 ${ }^{\circ} \mathrm{C}$. The plate was then blocked by dilution buffer $(0.1 \mathrm{M} \mathrm{NaH} 2 \mathrm{PO} 4 / \mathrm{Na} 2 \mathrm{HPO} 4, \mathrm{pH} 6.8$, $0.025 \%$ merthiolate, $0.5 \%$ bovine serum albumin, and $0.05 \%$ Tween-20) for 1 hour at $37^{\circ} \mathrm{C}$. IFN- $\alpha$ standards (in duplicates) and samples (in triplicates) were diluted in dilution buffer and were added to the plate followed by incubation for 2 hours at $37^{\circ} \mathrm{C}$. After adding detection antibody rat anti-mouse IFN- $\alpha$ (clone 4E-A1; $0.25 \mu \mathrm{g} / \mathrm{ml}$ ), plates were incubated for 1 hour at RT followed by addition of biotinylated sheep anti-rat $\mathrm{Ig}(1 \mu \mathrm{g} / \mathrm{ml})$ and incubated for 1 hour. ExtrAvidin-horseradish peroxidase was added to plates and incubated for 1 hour. Between each step plates were washed three times with PBS-0.5\% Tween-20. All reagents were diluted in dilution buffer. Plates were then developed by addition of adding $100 \mu 1$ of 3,3',5,5'tetramethylbenzidine (TMB) (Sigma) substrate solution. Colour developed was measured by an ELISA reader at $450 \mathrm{~nm}$.

\section{Luminex for quantification of cytokines (paper I)}

The levels of cytokines in serum from different time points of AIA were measured by bead based technology. This method utilizes colour coded polystyrene beads coated with capture antibody against specific analytes of interest. Multiple different analytes (cytokines, chemokines, growth factors, etc) can be quantified simultaneously in a small volume of sample. Analyte-specific beads are mixed and incubated with samples. Captured analytes are detected using a mixture of biotinylated detection antibodies and streptavidin-phycoerythrin (PE) conjugate. Analytes are then quantified using a two laser system of which, first laser classifies the specific bead and determines the analyte being detected. The second laser determines the intensity of PE signal which corresponds to the quantity of bound analyte.

We quantified IL-1 $\beta$, IL-6, IL-10, IL-12 (p70), IL-17, TNF, IFN- $\gamma$, and IL-13 in the serum using multiplex kit (Bio-Rad Laboratoires Inc, USA) according to manufacturer's protocol. The bound beads were read by Luminex-200 (Invitrogen) and data was analysed using Masterplex 2010 (version-5.0.0.68).

\section{Real Time PCR (qPCR) (Paper III)}

IDO1 and TGF- $\beta 1$ messenger RNA expression in spleen and draining lymph nodes or ex vivo mBSA-stimulated splenocytes were analysed at different time points of AIA. Spleens and lymph nodes were isolated at day $0,4,9,14,21$ and 28 of AIA and were stored in RNA later 
(Ambion, Thermofisher Scientific) at $-20^{\circ} \mathrm{C}$. Spleens and lymph nodes or splenocytes were homogenized and were mixed with TRI Reagent (Ambion) and 1-bromo,3-Chloropropanol (BCP) (Molecular Research Centre) and incubated at RT for 5 minutes followed by centrifugation at $12000 \mathrm{xG}$ for 10 minutes. The Aqueous phase was carefully isolated and mixed with isopropanol and $1 \mu 1$ glycoblue (Ambion) and centrifuged to precipitate total RNA. The precipitated RNA was washed three times with $70 \%$ ethanol and air dried at RT. The RNA pellet was then dissolved in RNAase free water (Quiagen) at $4{ }^{\circ} \mathrm{C}$. The concentration of RNA was quantified by Nanodrop (ND-1000 spectrophotometer, Life Science Technologies). Purity of total RNA was 1.8 - 2.0 based on A260/A280 values. 20ng of total RNA was converted to cDNA with reverse transcription kit (Life Technologies, California, USA) according to manufacturer's instructions. Universal Master Mix, IDO1 (Mm 00492586_m1) TGF- $\beta 1$ (Mm01178820_m1) and Actin- $\beta$ (Mm 00607939_s1) specific Taqman primer probes were used to perform real-time PCR using ABI Prosm 7900 fast PCR machine (Applied Biosystems). All samples and controls were run in duplicates. Actin- $\beta$ was used as an endogenous reference gene. $\Delta \mathrm{Ct}$ values were calculated as the difference of mean $\mathrm{Ct}$ values of reference gene (Actin- $\beta$ ) and the target gene (IDO1 or TGF- $\beta$ ). Relative expression of the target gene was calculated using $2^{-\Delta \Delta C t}$ (Livak's method) by normalizing with $\Delta \mathrm{Ct}$ values of spleens or LNs or Splenocytes from naïve mice.

\section{CFSE Suppression assay (Paper IV)}

Carboxyfluorescein succinimidyl ester (CFSE) is stable fluorescent dye that binds to covalently to intracellular molecules. Initially, carboxyfluorescein diacetate succinimidyl ester (CFDA-SE - non fluorescent molecule) was used to label the cells which, after diffusion into cytosol, converts into CFSE. The intensity of CFSE fluorescence halves when CFSE labelled cells divide once, thus, daughter cell populations can be assessed based on reduction of CFSE fluorescence intensity [201].

For the suppression assay, single cell suspension from spleens and draining lymph nodes from various time points of AIA was prepared as described above. Cells were stained with antimouse CD4-PE (Biolegend, San Diego, CA, USA) and anti-mouse CD25-APC (Biolegend). After staining, cells were sorted into Tresponders $\left(\mathrm{CD}^{+} \mathrm{CD} 25^{-}\right)$and Tregs $\left(\mathrm{CD} 4^{+} \mathrm{CD} 25^{\text {thigh }}\right)$ by cell sorter Aria-III as shown in figure 3. Besides sorting by FACS, Tregs and Tresponders were also sorted by combination of magnetic activated cell sorting (MACS) and FACS sorting. Sorted Tresponders and Tregs were re-analysed for purity and were at least $95 \%$ pure. We found $87-90 \%$ of sorted $\mathrm{CD} 4^{+} \mathrm{CD} 25^{\text {thigh }}$ cells were Foxp3 expressing T cells (Figure 4). 

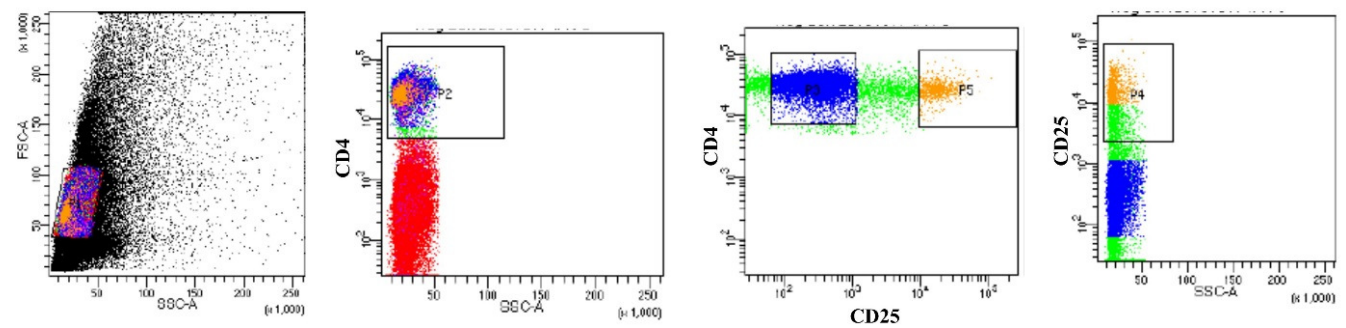

Figure 3. Gating strategies applied for sorting Tresponders $\left(\mathrm{CD} 4^{+} \mathrm{CD} 25^{-}\right)$and Tregs $\left(\mathrm{CD} 4^{+} \mathrm{CD} 25^{\text {thigh }}\right)$ from spleens and draining LNs.

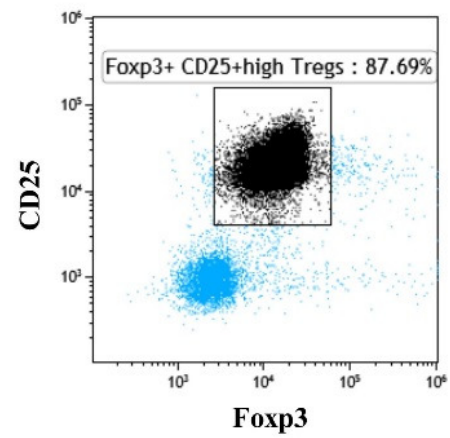

Figure 4. Purity of Foxp $3^{+}$Tregs in sorted $\mathrm{CD} 4^{+} \mathrm{CD} 25^{\text {thigh }} \mathrm{T}$ cells.

CFDA-SE (Sigma-Aldrich) at $5 \mu \mathrm{M}$ was added to sorted Tresponders and incubated for 5 minutes in darkness at RT. This was followed by washing the stained cells five times with FACS buffer (PBS+1\% FBS). 50,000 CFSE-stained cells were co-cultured with decreasing numbers of Tregs (i.e., 25,000, 12,500, 6,250 and 0) in a 96-well round bottom culture plate, resulting in Tregs:Tresponders ratio of 1:2, 1:4, 1:8 and 0:1 (Only Tresponders). For antigen presenting cells, 100,000 irradiated ( $25 \mathrm{~Gy}$ ) splenocytes from naïve mice were added to the wells. Cells (Tresp \pm Tregs + APC) were stimulated with mBSA $(50 \mu \mathrm{g} / \mathrm{ml})$ or anti-CD3 (1 $\mu \mathrm{g} / \mathrm{ml}$ ) and cultured for 72 hours at $37{ }^{\circ} \mathrm{C}$ in $5 \% \mathrm{CO}_{2}$ and $95 \%$ humidity. After 72 hours, cells were harvested and analysed for proliferation of CFSE-labelled Tresponders by FACS Gallios.

We observed a single proliferating peak of Tresponders with mBSA stimulation while compared to stimulation of naïve splenocytes with mitogen, Con-A $(1 \mu \mathrm{g} / \mathrm{ml})$ where we found 3-4 peaks (Figure 5). We believe this difference is attributable to mBSA-induced proliferation being only in mBSA-specific T-cells whereas polyclonal Con-A stimulation activates all T- 
cells. Tresponders do proliferate upon mBSA re-stimulation as the proliferation peak moves towards left in comparison to APC indicating reduction in CFSE intensity (non-proliferating region) (Figure 6). In future studies, in order to better study antigen-specific suppression, we will use the OT II transgenic mouse where a majority of $\mathrm{CD}^{+} \mathrm{T}$ cells are specific for ovalbumin.

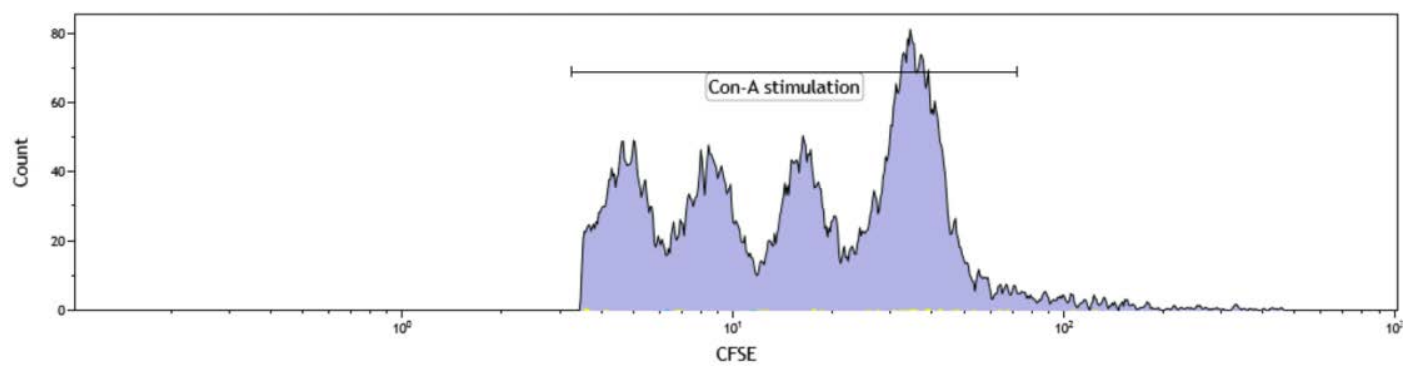

Figure 5. Depiction of proliferation peaks generated by cells stimulated with Con-A.

For the analysis, lymphocyte gate was selected based on forward and sideward scatter. CFSElabelled cells were selected and gated based on the cells from lymphocyte gate. Proliferated regions and non-proliferated regions were determined based on CFSE-labelled irradiated APC. The proliferated region was defined as $\mathrm{CFSE}^{\text {low }}$ region adjacent (left) to $\mathrm{CFSE}^{\text {high }}$ region (APC) as shown in figure 6.
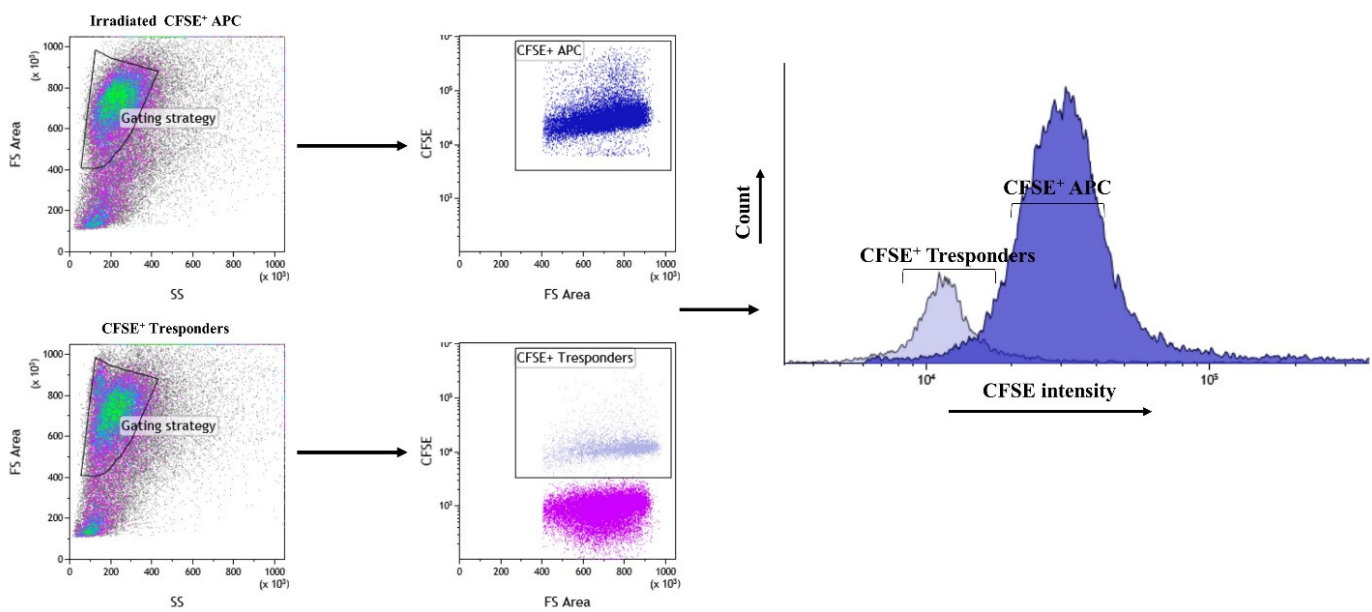

Figure 6. Gating strategies applied for calculation of suppression by Tregs against CFSE-stained Tresponders.

Suppression in percentage was calculated based on number of events in the proliferated region. 
Suppression in $\%=\frac{\text { Proliferation of Tresponders alone-Proliferation of Tresponders with Tregs }}{\text { Proliferation of Tresponders alone }} \times 100$

\section{In vivo depletion of Tregs (Paper IV)}

Foxp3DTReGFP mice (DEREG mice) were used for depletion of Tregs in AIA. In these mice, diphtheria toxin receptor (DTR) gene is coupled to green fluorescent protein (GFP) gene which are under control of the Foxp3 promoter region. Functional Foxp3 ${ }^{+}$Tregs express DTR-eGFP proteins thus facilitating fluorescent detection or DT-induced depletion of Foxp $3^{+}$ Tregs [202]. Foxp $3^{+}$Tregs are depleted in vivo for limited time, two days after administration of DT without affecting other cell populations [203]. Foxp3 $3^{+}$Tregs re-populate to normal count in 7-10 days after administration of DT. After several optimizations, we found a single dose of $250 \mu \mathrm{g}$ (in $100 \mu \mathrm{l}$ of PBS) of DT injected i.p. was effective and depleted $90 \%$ of Foxp $3^{+}$Tregs in vivo in the blood and in the spleens (data not shown). Thus, we used a single dose of $250 \mu \mathrm{g}$ of DT to deplete Foxp $3^{+}$Tregs in vivo at day 0, 5 and 19 of AIA.

\section{Adoptive transfer of Tregs (Paper IV)}

Single cell suspensions were made from spleens and draining lymph nodes collected at day 20 of AIA from PBS-treated or IFN-treated mice. CD4 $4^{+} \mathrm{CD} 25^{\text {thigh }}$ Tregs were sorted as mentioned above and were washed, counted and re-suspended in PBS. 50,000-250,000 Tregs $(50-100 \mu 1)$ were administered intravenously though tail vein at day 20 of AIA. The following dat (day 21), arthritis was induced in the recipient mice (depicted in figure 7). On day 28, mice were sacrificed and knee joints were isolated for histopathological examination for arthritis severity. 


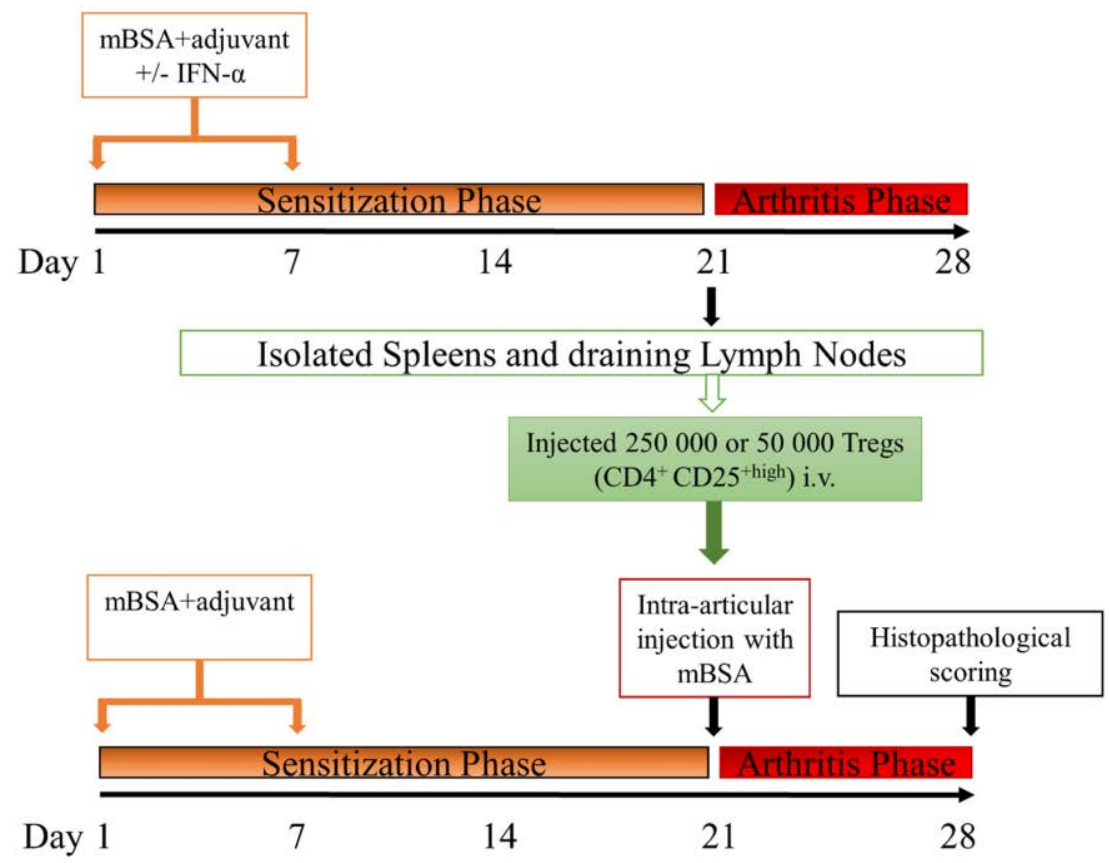

Figure 7. Schematic representation of adoptive transfer of Tregs.

\section{Tryptophan and Kynurenine quantification (paper III)}

We used High Performance Liquid Chromatography (HPLC) to quantify tryptophan (Trp) and kynurenine (Kyn) levels in the serum. Standards of Trp and Kyn were prepared in albumin solution ranging from $0.5 \mu \mathrm{M}$ ot $50 \mu \mathrm{M}$. A $100 \mu \mathrm{l}$ mixture of methanol:acetyl nitrile and methyl guanosine (internal standard) was added and mixed with $50 \mu 1$ of serum sample or standards. Samples were centrifuged at $10,000 \mathrm{rpm}$ for $10 \mathrm{~min}$. Samples were then diluted 5 times with $10 \mathrm{mM}$ acetic acid. Thereafter, $10 \mu \mathrm{l}$ of samples were injected into the HPLC system. Standards and samples were analysed on a Waters 2695 HPLC system with a 2475 multi wavelength fluorescence detector (Waters Corp., Milford, USA) utilizing Empower Chromatography Data Software. Kyn was measured at $480 \mathrm{~nm}$, Trp at $350 \mathrm{~nm}$ and internal standard at $390 \mathrm{~nm}$. The results are expressed as the Kyn:Trp. 


\section{Results and Discussion}

Please note that this section describes and discusses the main findings of previous research papers and research papers included in this thesis. Kindly refer to specific research paper for full results and discussion.

\section{Local but not systemic administration of uridine prevents development of AIA (Paper I)} Systemic administration of uridine does not inhibit development of mBSA-induced arthritis.

Uridine is a pyrimidine nucleoside that has been shown to down-modulate inflammation in experimental models of lung inflammation. Therefore, the aim of this paper was to evaluate efficacy of uridine as an anti-arthritic molecule in AIA. We investigated if systemic administration of uridine had any effect in AIA. To this end, $0-100 \mathrm{mg} / \mathrm{kg}$ of uridine was administered systemically (s.c. on day 0, 7, 14 (i.p.), 21 and 23 or sustained-release pellets) in mBSA-sensitized mice. We did not observe any effect of systemic administration of uridine (different doses) on AIA (Figure $8 \mathrm{~A} \& \mathrm{~B}$ ). Exogenous uridine is rapidly metabolized in vivo by the liver and the half-life of uridine is about 2 minutes [204, 205]. The rapid pharmacokinetics of uridine in vivo and problem with maintaining sufficient amounts of uridine locally in the knee joint could probably explain the lack of effect seen with systemic administration of uridine. As mentioned earlier, TNF, IL- 6 and IL-1 $\beta$ play a crucial role in the pathogenesis of RA and AIA. In line with lack of effect on arthritis systemic administration of uridine did not have any effect on systemic levels of pro-inflammatory cytokines (IL-6, IL-1 $\beta$, IL-12, IL-17 and IFN- $\gamma$ ) though a small and significant reduction in TNF was observed in animals that received $100 \mathrm{mg} / \mathrm{kg}$ of uridine (data not shown).
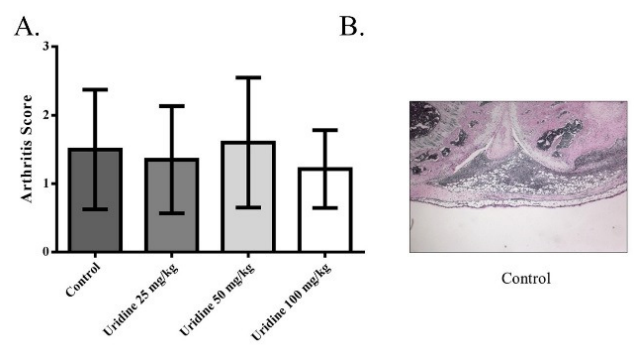

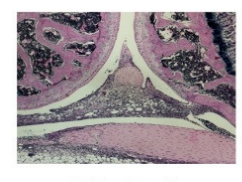

Uridine $25 \mathrm{mg} / \mathrm{kg}$

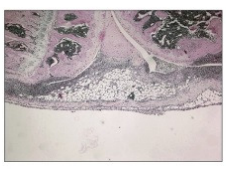

Uridine $50 \mathrm{mg} / \mathrm{kg}$

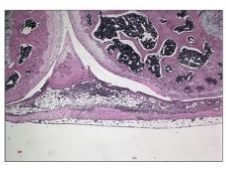

Uridine $100 \mathrm{mg} / \mathrm{kg}$

Figure 8. Systemic administration of uridine does not inhibit development of mBSA-induced arthritis. Multiple doses of $0-100 \mathrm{mg} / \mathrm{kg}$ of Uridine was administered systemically in mBSA-sensitized mice on day 0,7 , 14 (i.p.), 21 and 23. On day 21, arthritis was induced by injecting mBSA intra-articularly in the mice as 
described in methods. At day 28, mice were sacrificed and knee joints were isolated and prepared for histopathological evaluation as described in the methods. (A) Arthritis Severity (median with interquartile range). $0 \mathrm{mg} / \mathrm{kg}(\mathrm{n}=20), 25 \mathrm{mg} / \mathrm{kg}(\mathrm{n}=10), 50 \mathrm{mg} / \mathrm{kg}(\mathrm{n}=15)$ and $100 \mathrm{mg} / \mathrm{kg} \mathrm{mg} / \mathrm{kg}(\mathrm{n}=7)$. Data show results of two pooled experiments. (B) Representative images of joint sections of each treatment group. ${ }^{*} \mathrm{p}<0.05$, (Mann-Whitney).

\section{Local administration of uridine inhibits development of mBSA-induced arthritis in dose dependent manner.}

Intra-tracheal (local) administration of uridine has been to shown to inhibit inflammation in a sephadex-induced lung inflammation model. Therefore we investigated if local administration of uridine could have any effect in AIA. We administered a single dose of 0, 25, 50 or 100 $\mathrm{mg} / \mathrm{kg}$ of uridine locally in the knee joint during arthritis induction (day 21 of AIA). There was a significant and dose dependent reduction in arthritis severity compared to control animals. Mice receiving $100 \mathrm{mg} / \mathrm{kg}$ of uridine displayed maximum reduction of arthritis severity (Figure 9 A\&B).

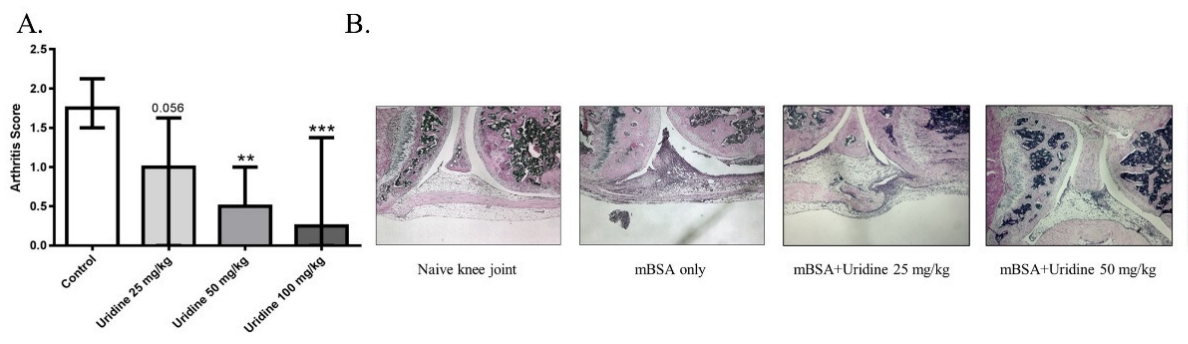

Figure 9. Local administration of uridine inhibits development of mBSA-induced arthritis in dose dependent manner. Single dose of $0-100 \mathrm{mg} / \mathrm{kg}$ of Uridine was co-administered locally along with $30 \mu \mathrm{g}$ mBSA (intra-articularly) in right knee joint in mBSA-sensitized mice on day 21 . At day 28 , mice were sacrificed and knee joints were isolated and prepared for histopathological evaluation as described in the methods. (A) Arthritis Severity (median with interquartile range) $0 \mathrm{mg} / \mathrm{kg}(\mathrm{n}=11), 25 \mathrm{mg} / \mathrm{kg}(\mathrm{n}=6), 50 \mathrm{mg} / \mathrm{kg}(\mathrm{n}=7)$ and $100 \mathrm{mg} / \mathrm{kg}(\mathrm{n}=12) . \mathrm{n}>6, * \mathrm{p}<0.05, * * \mathrm{p}<0.01, * * * \mathrm{p}<0.001$ (Mann-Whitney). Data show results of two pooled experiments. (B) Representative images of joint sections of each treatment group.

\section{Local administration of uridine suppressed synovial expression of IL-6 \& TNF, synovial cell influx and synovial expression of ICAM-1 \& CD18.}

Recruitment of leukocytes through endothelial extravasation to the knee joint in RA is probably critical for mounting an adequate pro-inflammatory response and blocking this extravasation is a novel target for therapeutic modulation of inflammation. We then moved on to determine which cell types were affected by local administration of uridine. Local administration of uridine inhibited the influx of $\mathrm{T}$ cells, macrophages and neutrophils in a 
dose dependent manner as shown in figure $10 \mathrm{C}$-E. Recruitment of leukocytes to the site of injury is one of the initial events in inflammation involving expression and activation of cellular and endothelial adhesion molecules. The significant reduction in the influx of leukocytes to the synovium of locally treated joints prompted us to investigate the effects on locally administered uridine on synovial adhesion molecules. For synovial adhesion molecules, we determined synovial expression of ICAM-1 and CD18. Local administration of uridine significantly suppressed synovial expression of ICAM-1 and CD18 in a dose dependent manner (Fig. 10 F-G).

A.

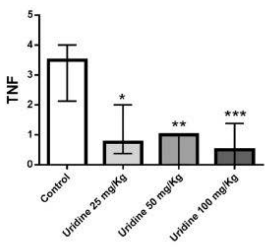

F.

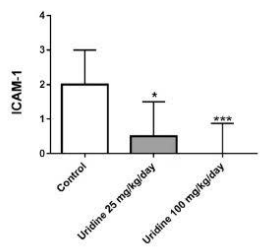

B.

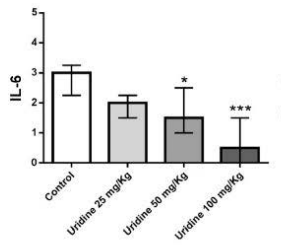

G.

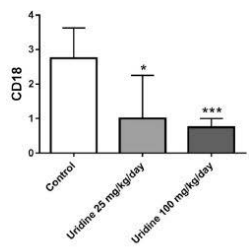

C.

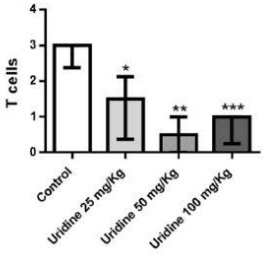

D.

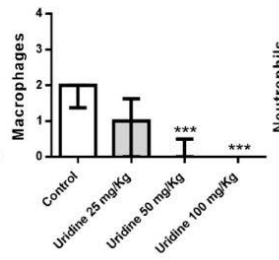

E.

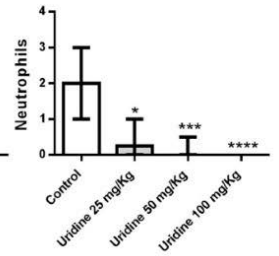

Figure 10. Local administration of uridine suppressed synovial expression of IL-6 \& TNF, synovial cell influx and synovial expression of ICAM-1 \& CD18. Single dose of $0-100 \mathrm{mg} / \mathrm{kg}$ of uridine was coadministered locally (intra-articularly) along with mBSA in right knee joint in mBSA-sensitized mice on day 21 . At day 28 , mice were sacrificed and knee joints were isolated and prepared for immunohistochemistry staining and evaluation. (A-B) Immunohistochemistry scoring of non-treated and treated groups for TNF- $\alpha$ and IL- 6 expression (median with interquartile range). (C-E) Immunohistochemistry scoring of non-treated and treated groups for T cells, Macrophages and Neutrophils (median with interquartile range). (F-G)

Immunohistochemistry scoring of non-treated and treated groups for ICAM-1 and CD18 expression (median with interquartile range). $0 \mathrm{mg} / \mathrm{kg}(\mathrm{n}=6), 25 \mathrm{mg} / \mathrm{kg}(\mathrm{n}=6), 50 \mathrm{mg} / \mathrm{kg}(\mathrm{n}=7), 100 \mathrm{mg} / \mathrm{kg}(\mathrm{n}=12)$ of uridine. * $\mathrm{p}<0.05, * * \mathrm{p}<0.01, * * * \mathrm{p}<0.001, * * * * \mathrm{p}<0.0001$ (Mann-Whitney).

Further, local administration of uridine clearly inhibited synovial expression of TNF and IL-6

(Fig. A-B) without affecting systemic levels of these cytokines and systemic immune responses to mBSA. Intra-tracheal administration of uridine has been shown to inhibit the secretion of TNF, IL-6 and IL-8 into bronchoalveolar fluid [197, 206]. Given the inhibitory effect of uridine on TNF, uridine also reduced synovial adhesion molecules which aid in extravasation and are regulated by TNF [207, 208]. It is difficult to elucidate if decreased expression of pro-inflammatory cytokines in uridine treated joints was due to down 
modulation of influx of TNF and IL-6 producing or by suppressed synovial pro-inflammatory cytokines production per se.

In this paper we speculate that the anti-arthritic effect of uridine was primarily associated with reduced synovial adhesion molecules and secondarily due to decreased extravasation of inflammatory leukocytes and inhibition of synovial IL-6 and TNF production.

\section{Dendritic Cells activated by double-stranded RNA induce arthritis via autocrine type I IFN signalling (Paper II).}

In many autoimmune diseases such as SLE, Sjögrens syndrome and RA, DCs play a pathogenic role and are known to migrate from the circulation to site of inflammation. An etiological factor in arthritis, arthralgias and possibly also in RA could be viral infections [4]. In fact, IFN- $\alpha$ or interferogenic viral dsRNA can be found at the site of inflammation in RA patients and presence of dsRNA is correlated to erosive disease [24]. A pro-inflammatory role of dsRNA and IFN- $\alpha$ in the synovium is supported by earlier findings showing that viral dsRNA or IFN- $\alpha$ injected into the knee joint induces arthritis in a type I IFN receptor dependent manner [25]. The major IFN- $\alpha$ producing cell is the $\mathrm{pDC}$, but other DC may also produce IFN- $\alpha$ in response to viral stimuli [31]. We therefore aimed to determine the occurrence of different DC populations in dsRNA-induced arthritis and their ability to mediate dsRNA-induced arthritis.

\section{Dendritic cells accumulate in dsRNA-induced arthritis.}

In this model, dsRNA injected in the knee joint activates type I IFN signalling and induces a transient synovial inflammation which is dependent on the innate immune system since dsRNA induces arthritis in severe combined immune-deficient (SCID) mice that lack functional adaptive immune cells (T cells and B cells) [103, 104]. Three days post-injection, we investigated the occurrence of both pDC and mDC using DC-specific markers in the knee joint by immunohistochemistry. The arthritic joints contained cells expressing CD11c (Pan DC-marker), $120 \mathrm{G} 8$ (pDC marker) and MHC class II (Fig. 11 A, B \& C). We could not detect DCs in vehicle-injected joints (data not shown). In line with this, in RA patients, both cDC and $\mathrm{pDC}$ were detected in the inflamed synovium though their role in aetiopathogenesis needs to be determined $[209,210]$. 

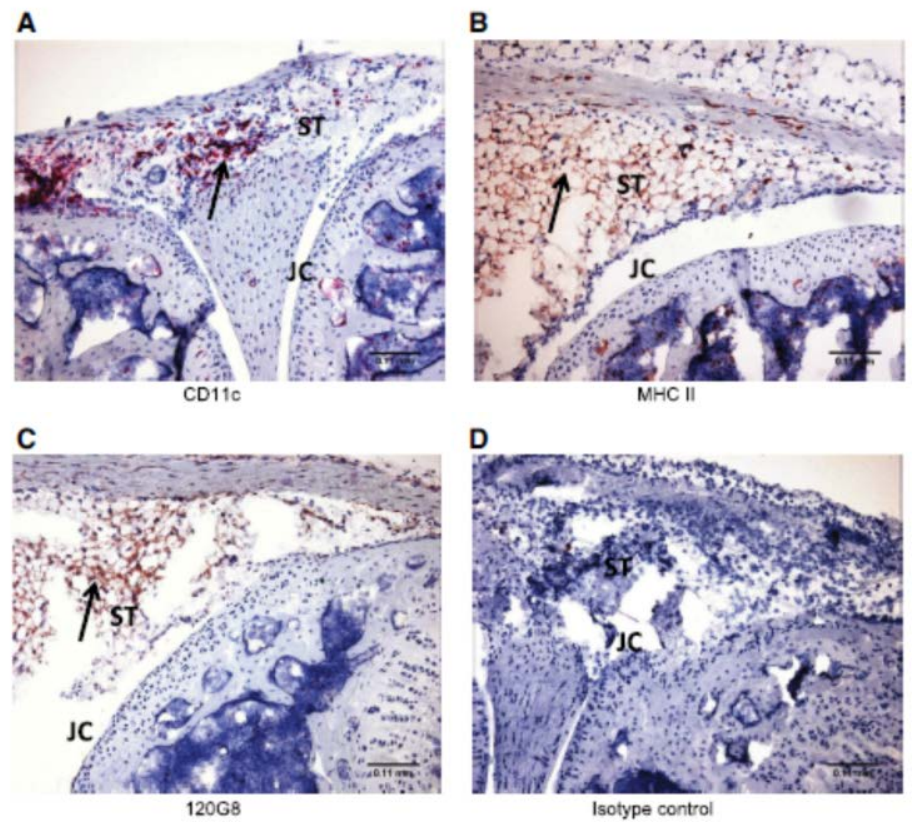

Figure 11. Dendritic cells accumulate in dsRNA-induced arthritis. Double stranded RNA ( $5 \mu \mathrm{g})$ was injected intra-articularly in the left knee as described in [103]. Three days after the injection, the knee joint was isolated, prepared and cryosectioned for staining with rat anti mouse CD11c (A), MHC class II (B), plasmacytoid DC marker 120G8 (C) and isotype control (D). Representative images from 1 of 4 dsRNA-treated mice are shown. $\mathrm{ST}=$ synovial tissue, $\mathrm{JC}=$ joint cavity, $\mathrm{V}=$ blood vessel. Arrows indicate infiltration of inflammatory cells. Magnification=10x.

\section{dsRNA-activated, Flt3L-derived DCs induce arthritis.}

We next determined if the presence of DCs was sufficient to induce inflammation. For this, we generated Flt3L-derived DCs from bone marrow and stimulated them with medium alone or dsRNA as described in the methods. Subsequently, treated DCs were injected into the healthy knee joint and arthritis severity was evaluated after three days. Mere presence of DCs in the knee joint was not sufficient for induction of arthritis (Fig. 12 A, B). However, DCs pre-stimulated with dsRNA induced arthritis (Fig. 12 A, B). Similarly, DCs loaded with necrotic cells that contain nucleic acids induced renal manifestation of lupus-like nephritis [211]. dsRNA is one such factor that is known to drive DCs in pathogenesis of SLE and breach the tolerance against self-peptides causing autoimmunity [212, 213]. Many viruses are known to cause post-infectious arthritis that is transient and self-limiting [3]. dsRNA is a common viral nucleic acid and is the product of viral replication that has an ability to induce arthritis [104]. 


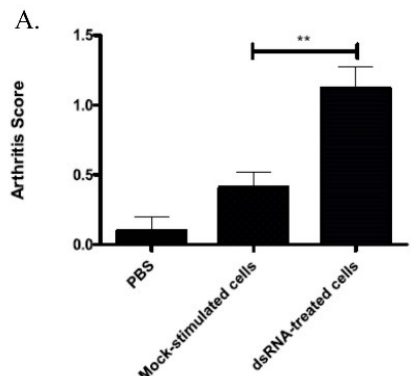

B.
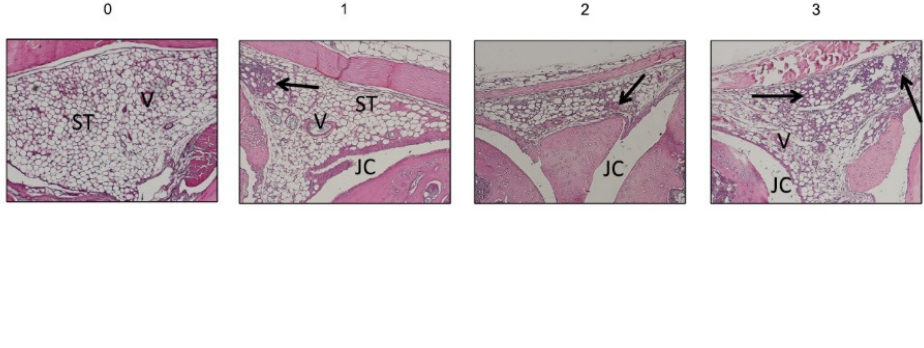

Figure 12. DsRNA-activated Flt3L-derived DC induce arthritis. Flt3-generated DC were isolated from bone marrow cells cultured in the presence of $25 \mathrm{ng} / \mathrm{ml}$ recombinant murine Flt3-ligand for 9 days (A). Flt3-generated DC harvested and treated 4 hours with medium (mock-stimulated cells), or dsRNA. Washed cells (80 000 cells in $20 \mu \mathrm{l}$ ) were thereafter injected intra-articularly into the left knee joint of healthy mice. As control, $20 \mu \mathrm{l}$ PBS was injected in the right knee. Three days post-injection joints were evaluated for arthritis. Mean severity (arthritic score 0-3) of arthritis. ** $\mathrm{p}<0.01$ (Mann Whitney). The data are pooled from 4 independent experiments. (B) Representative images of joints with arthritic score 0-3 from mice injected with mockstimulated or dsRNA-stimulated Flt3L-derived DC. ST= synovial tissue, JC=joint cavity, V= blood vessel. Arrows indicate infiltration of inflammatory cells. Magnification=10x.

\section{The Arthritogenicity of ds-RNA-activated, Flt3L-derived DCs is dependent on functional IFNAR.}

The ability of dsRNA to induce arthritis is essentially dependent on production of IFN- $\alpha$ and type I IFN signalling [103]. We investigated the arthritogenic capacity of dsRNA-activated, Flt3L-derived DCs and if this capacity was dependent on functional IFNAR. We injected dsRNA-activated, Flt3L-derived DCs from WT or IFNAR KO (donor) mice, intra-articularly into WT or IFNAR KO recipient mice. IFN- $\alpha$-expressing DCs were highly arthritogenic in contrast to DCs lacking type I IFN signalling were not (Fig. 13). The ability of dsRNA-treated DCs to induce arthritis when adoptively transferred to a healthy joint was dependent on type I IFN signalling in donor DCs whereas expression of IFNAR was not required in the recipient mice (Fig. 13A) for development of arthritis. In line with arthritogenicity of IFN signalling competent DC, DCs from WT mice produced IFN- $\alpha$ upon dsRNA stimulation as opposed to DCs from IFNAR KO mice treated with dsRNA. The lack of type I IFN signalling and inability to produce IFN- $\alpha$ could possibly explain why dsRNA-treated DCs from IFNAR KO mice were incapable of inducing arthritis. On the contrary, dsRNA-treated DCs from WT mice could induce arthritis in IFNAR KO mice even though these mice lacked type I IFN signalling (Fig. 13B). This could possibly be explained by the fact that donor WT dsRNAtreated DCs were activated further by autocrine IFN signalling which was sufficient to drive arthritis. Autocrine type I IFN signalling is one way by which DCs undergo activation and 
maturation by expressing co-stimulatory and adhesion molecules and thus aid in recruitment of other immune cells [214].

A

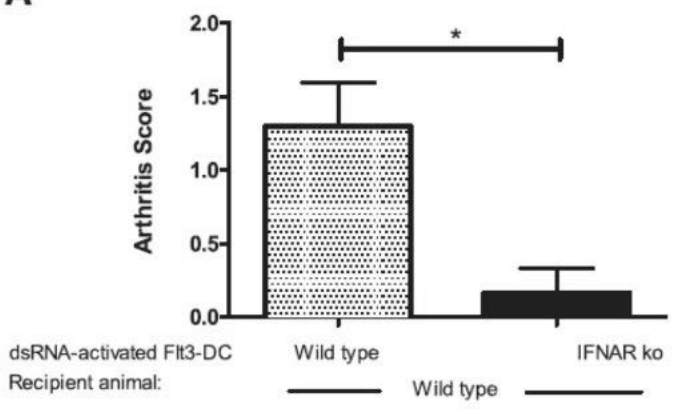

B

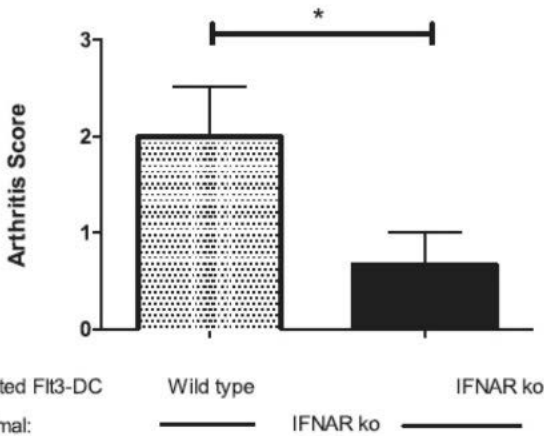

Figure 13. The arthritogenicity of dsRNA-activated Flt3L-derived DC is dependent on a functional type I IFN receptor. Flt3L-derived DC were generated from bone marrow cells from wt (A) and IFNAR ko mice (A129) (B) as described in matrials and methods. They were harvested and treated $4 \mathrm{~h}$ with dsRNA $(150 \mu \mathrm{g} / \mathrm{ml}$ poly I:C) and subsequently washed and injected (80 000 cells in $20 \mu \mathrm{l})$ intra-articularly into the left knee joint of wt and A129 mice. As control, $20 \mu \mathrm{l}$ PBS was injected in the right knee (data not shown). Three days postinjection, joints were evaluated for arthritis. (A) shows DC from wt mice and IFNAR ko mice injected into wt mice and (B) shows DC from wt and IFNAR ko mice injected into IFNAR ko mice. (A and B) Mean severity (arthritic score 0-3) of arthritis. * $\mathrm{p}<0.05$ (Mann Whitney).

\section{Both cDC and pDC are arthritogenic if pretreated with dsRNA.}

Earlier we have shown that dsRNA-treated Flt3L-derived DCs induce arthritis, but this pool of DCs contain $\mathrm{cDC}\left(\mathrm{CD} 11 \mathrm{c}^{+} \mathrm{PDCA}^{-} 1^{-}\right), \mathrm{pDC}\left(\mathrm{CD} 11 \mathrm{c}^{+} \mathrm{PDCA}-1^{+}\right)$and non-DC $\left(\mathrm{CD} 11 \mathrm{c}^{-}\right.$ PDCA-1 ${ }^{-}$) populations. Since both of these DCs are present in the inflamed synovium of dsRNA-induced arthritis and have the capacity to express IFN- $\alpha$ upon dsRNA stimulation, we wanted to investigate the arthritogenic capacity of each of these cell populations. For this, Flt3L-DCs were sorted into cDC (CD11 $\mathrm{c}^{+}$PDCA-1- $)$, pDC $\left(\mathrm{CD} 11 \mathrm{c}^{+}\right.$PDCA- $\left.{ }^{+}\right)$and non-DC $\left(\mathrm{CD} 11 \mathrm{c}^{-} \mathrm{PDCA}-1^{-}\right)$populations and treated with dsRNA before being injected intraarticularly as described in methods section. Both types of dsRNA-treated DCs induced 
arthritis (Fig. 14) and produced IFN- $\alpha$ whereas non-DCs, despite dsRNA stimulation, did not induce arthritis.

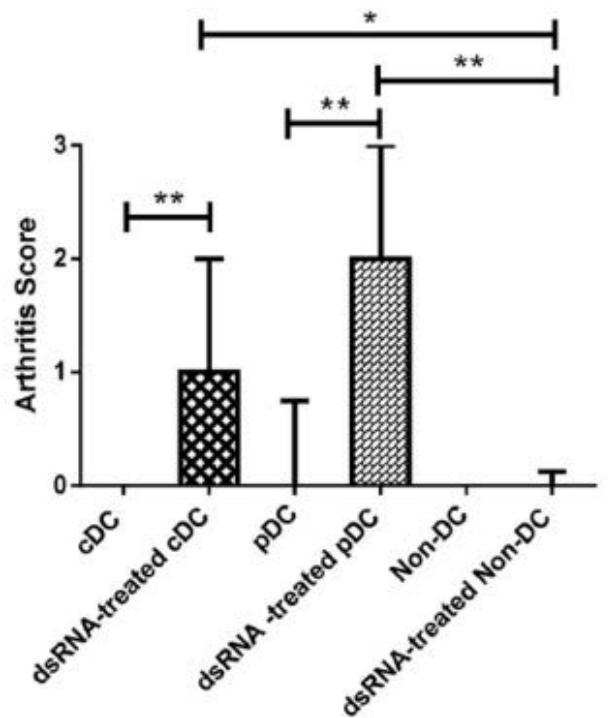

Figure 14. Both $\mathbf{c D C}$ and pDC are arthritogenic if pretreated with dsRNA. Flt3L-bone marrow derived DCs were sorted into CD $11 \mathrm{c}^{+}$PDCA-1- $(\mathrm{cDC}), \mathrm{CD} 11 \mathrm{c}^{+}$PDCA-1 ${ }^{+}$(pDC) and CD1 $1 \mathrm{c}^{-}$PDCA-1- (non-DC) and cultured for $4 \mathrm{~h}$ with dsRNA (poly I:C $150 \mu \mathrm{g} / \mathrm{ml}$ ) before intra-articular injection as described in methods. Three days post-injection the arthritic score was determined. Mean severity (arthritic score 0-3) of arthritis is depicted in figure for sorted Flt3L-DC $(n \geq 6)$. The non-DC population (double negative) that did not induce arthritis is included. $*=\mathrm{p}<0.05$ (Mann Whitney).

This paper demonstrates that dsRNA-activated DC induce arthritis in a type I IFN-dependent manner. Once activated, autocrine type I IFN signalling in DC is sufficient to establish arthritis. In some of viral infections caused by alpha viruses, HTLV-1, and B19 parvovirus, nucleic acids found in the synovium are associated with development of arthritis similar to RA [3]. We therefore speculated that viral nucleic acids in the synovium of post-infectious patients could trigger and propagate inflammation via DCs.

The aetiopathogenesis of RA is closely associated with variation in MHC genes and is characterised by high levels of autoantibodies against IgG (RF) and ACPA. Thus, both cellular and humoral components play a role in the development of RA. To study how dsRNA, a product of viral replication, would affect arthritis induced by cellular and humoral immunity, we continued our studies using the mBSA-induced arthritis model (mentioned in detail in methods section). Administration of dsRNA during the development of immune responses against mBSA totally down modulated the development of arthritis. This protective effect, mediated by dsRNA-induced type I IFN signalling, inhibited antigen-specific 
proliferation [111]. Moreover, endogenous IFN- $\alpha$ signalling mitigated arthritis development because mice lacking the type I IFN receptor (IFNAR KO) developed more severe arthritis than wild-type mice [111]. Thus in apparent contrast to the arthritogenic effect of dsRNA and IFN- $\alpha$ when present in the joint $[103,104]$, activation of type I IFN signalling during development of antigen-induced arthritis is clearly anti-inflammatory.

\section{IDO1 and TGF- $\beta$ Mediate Protective Effects of IFN- $\alpha$ in Antigen-Induced Arthritis (Paper III).}

\section{TGF- $\beta$ mediates the protective effect of IFN- $\alpha$ in AIA.}

We have earlier shown that dsRNA or IFN- $\alpha$ down modulated AIA when administered during development of anti-mBSA specific responses. In contrast, there was no direct antiinflammatory effect because treatment with IFN- $\alpha$ after the induction of arthritis did not affect the arthritis severity [111]. This protective effect of IFN- $\alpha$ was associated with higher serum TGF- $\beta$ levels both in the sensitization phase and arthritis phase of AIA in IFN- $\alpha$ treated mice compared to controls [112]. Hence, we wanted to determine if the protection by IFN- $\alpha$ was mediated by TGF- $\beta$. We blocked TGF- $\beta$ using a blocking antibody against TGF- $\beta$ during the sensitization phase (Day 0-9) or the arthritis phase (Day 20-27). The protective effect of IFN$\alpha$ was abolished when TGF- $\beta$ was blocked during the sensitization phase (Fig. 15A). On the other hand, IFN- $\alpha$ was able to render its protective effect even if TGF- $\beta$ was blocked during the arthritis phase (Fig. 15A). Taken together, TGF- $\beta$ is essential in the sensitization phase for protection rendered by IFN- $\alpha$ against AIA but not during the arthritis phase.

A

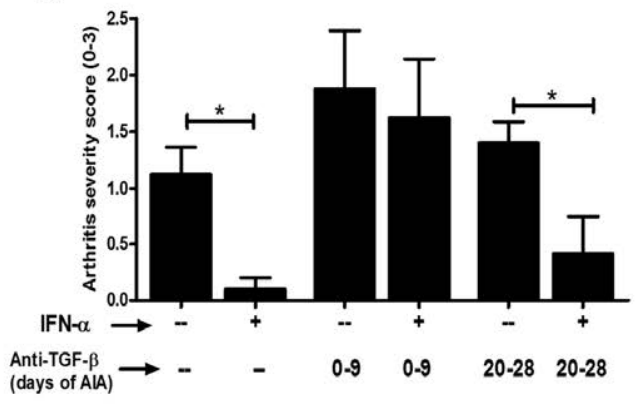

B

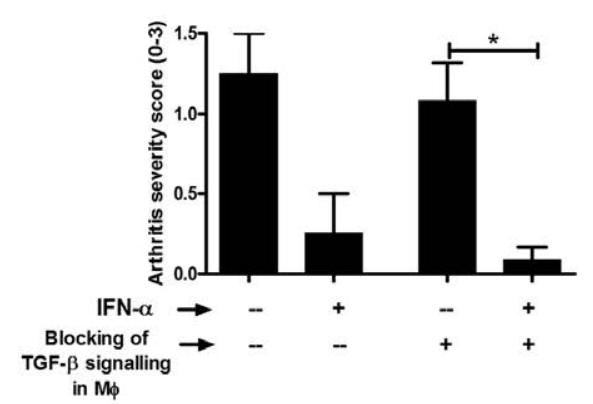

Figure 15. The protective effect of IFN- $\alpha$ against AIA is mediated by TGF- $\beta$ signalling in the sensitisation phase. AIA was induced in WT Sv129 mice and LysM Cre $e^{+/-}$Tgfbr2flox/flox with or without IFN- $\alpha$ treatment. TGF- $\beta$ signalling was blocked in WT mice by daily i.p injection of $150 \mu \mathrm{g}$ anti-TGF- $\beta$ antibody for the first $0-9$ or 20-28 days of AIA. (A) The level of arthritis expressed as severity score (mean \pm SEM, $n \geq 4$ ) from WT mice with or without IFN- $\alpha$ and anti-TGF- $\beta$ treatment. (B) The level of arthritis expressed as severity score (mean \pm SEM, $\mathrm{n} \geq 6$ ) from LysM Cre+/-Tgfbr2flox/flox mice with or without IFN- $\alpha$ treatment. Comparison of 
arthritis severity score between different groups was done by Mann Whitney $\mathrm{U}$ test $(* \mathrm{P}<0.05)$.

As mentioned in the introduction, TGF- $\beta$ is produced by various cell types but Macrophages $(\mathrm{M} \varphi)$ serve as a vital source of TGF- $\beta$ [215]. Previously, we observed an increase in TGF- $\beta$ expression in $\mathrm{M} \varphi$ from ex vivo re-stimulated leukocytes in IFN- $\alpha$ treated animals when compared to control animals [112]. Further, since TGF- $\beta$ is essential in the sensitization phase for IFN- $\alpha$ mediated protection, we decided to investigate the importance of TGF- $\beta$ signalling in $\mathrm{M} \varphi$ in IFN- $\alpha$ treated animals. We utilized LysM Cre+Tgfbflox/flox mice that were devoid of TGF- $\beta$ gene specifically in M $\varphi$. IFN- $\alpha$ protected these mice against AIA to similar extent as mice with intact TGF- $\beta$ gene in $\mathrm{M} \varphi$ (Fig. 15B). This effect could be explained by ability of other cells such as $\mathrm{CD}^{+} \mathrm{T}$ cells [112] and $\mathrm{pDC}$ [216] to produce TGF- $\beta$. Hence, abrogating an individual source of TGF- $\beta$ may not necessarily change the magnitude of TGF- $\beta$ production in vivo.

\section{IDO1 mediates the protective effect of IFN- $\alpha$ in AIA.}

\section{The protective effect of IFN- $\alpha$ in AIA is accompanied by induction of IDO1 expression and activity.}

Type I and II IFNs and TGF- $\beta$ are important inducers of IDO1 during inflammation [156, $217,218]$. Earlier, we observed increased expression of TGF- $\beta$ in serum and in supernatants of ex vivo mBSA re-stimulated leukocytes in IFN- $\alpha$ treated animals. In this paper, we wanted to determine if IFN- $\alpha$ mediated protection was dependent on IDO1.

We quantified IDO1 gene expression in spleens and lymph node cells from IFN- $\alpha$ treated or control mice at day $0,4,10,14,21,24$ and 28 of AIA. Higher gene expression of IDO1 though not significant was seen on day 4 in spleens and LNs in IFN- $\alpha$ treated animals compared to control mice (Figure $16 \mathrm{~A}$ ). 


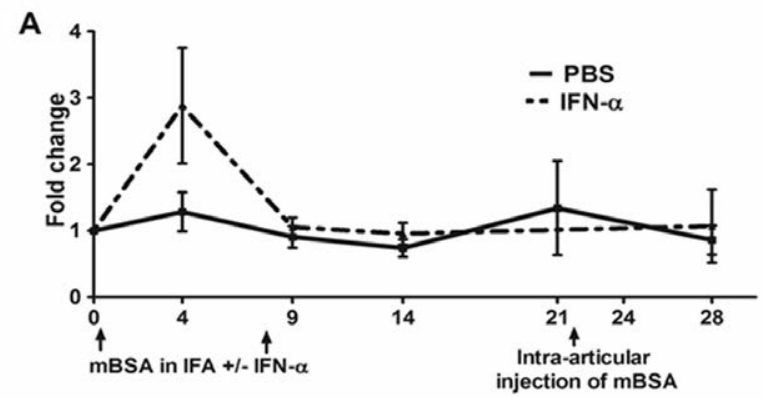

B

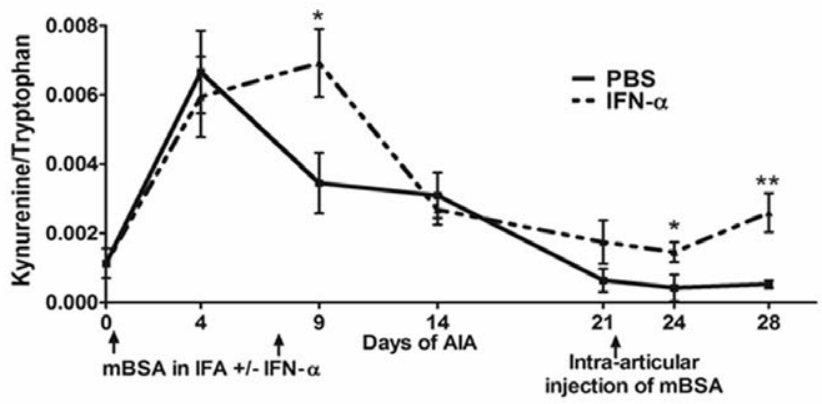

Figure 16. The protective effect of IFN- $\alpha$ in AIA is accompanied by induction of IDO1 expression and activity. A) During AIA, mBSA-sensitized mice treated with or without IFN- $\alpha$ treatment, spleens were collected at day $0,4,10,14,21$ and 28 and analysed for relative Ido1 mRNA by Real Time-PCR. Data are expressed as fold change normalized to the reference gene Actin B and Idol gene expression in spleens from naïve mice, $n \geq 4$. B). Sera were collected at day $0,4,10,14,21,24$ and 28 of AIA and analysed for Trp and Kyn concentration by HPLC. Data are expressed as the ratio of serum levels of Kyn to Trp, $n \geq 7$.

Enzymatic catabolism of Trp by IDO1 causes Trp deprivation and conversion to immuneregulatory Kyn which is one of the tolerogenic mechanisms mediated by IDO1. Next, we wanted to measure the enzymatic activity of IDO1 (Kyn/Trp ratio) in serum of mice that received IFN- $\alpha$ or PBS. Kyn/Trp ratio peaked at day 4 in both groups, but thereafter, the ratio remained high during the sensitization after second dose of IFN- $\alpha$ (day 9) and after arthritis induction in IFN- $\alpha$ treated animals compared to control animals (Fig. 16B ).

Combing both the results, IFN- $\alpha$ treatment induced IDO1 expression in splenocytes at day 4 during sensitization and enzymatic activity of IDO1 was much more enhanced during antigen sensitization and arthritis induction.

\section{IDO1 expression is required for the protective effect of IFN- $\alpha$.}

Then, we moved on to examine whether IDO1 is essential for IFN- $\alpha$ mediated protection in AIA. To answer this, we used mBSA-sensitized $\mathrm{IDO}^{-/-}$mice or WT control mice treated with 
or without IFN- $\alpha$ as described in the methods section. The protective effect of IFN- $\alpha$ which was evident in the WT siblings was totally abolished in IDO1 $1^{-/-}$mice (Fig. 17 A). This indicates that IDO1 expression is essential for IFN- $\alpha$ mediated protection in AIA. In our previous research paper, we have shown that protection conferred by IFN- $\alpha$ was associated with suppressed proliferation of leukocytes (splenocytes or LN cells) from IFN- $\alpha$ treated mice upon mBSA re-stimulation [111]. Next, we investigated if the IFN- $\alpha$-induced inhibitory effect on leukocyte proliferation upon mBSA-restimulation was dependent on IDO1. To this end, we re-stimulated splenocytes and LN cells ex vivo from mBSA-sensitized $\mathrm{IDO}^{-/}$mice. In absence of IDO1, the IFN- $\alpha$-induced inhibitory effect on mBSA re-stimulated leukocyte proliferation was completely lost (Fig. 17B). Hence, IFN- $\alpha$-induced antigenspecific tolerance in the sensitization phase depends upon functional IDO1. In line with our studies, it was reported that CpG DNA, a type I IFN inducer, inhibited T cell proliferation via induction of IDO1 in a manner dependent on IFN- $\alpha$ signalling [175, 219].

Taken together, the protective effect of IFN- $\alpha$ against AIA and IFN- $\alpha$-induced inhibitory effect on antigen re-stimulated leukocytes is mediated by IDO1. Supporting our studies, other research groups have elucidated the anti-inflammatory role of IDO1 in down modulating CIA, EAE and IBD [182, 183, 220].
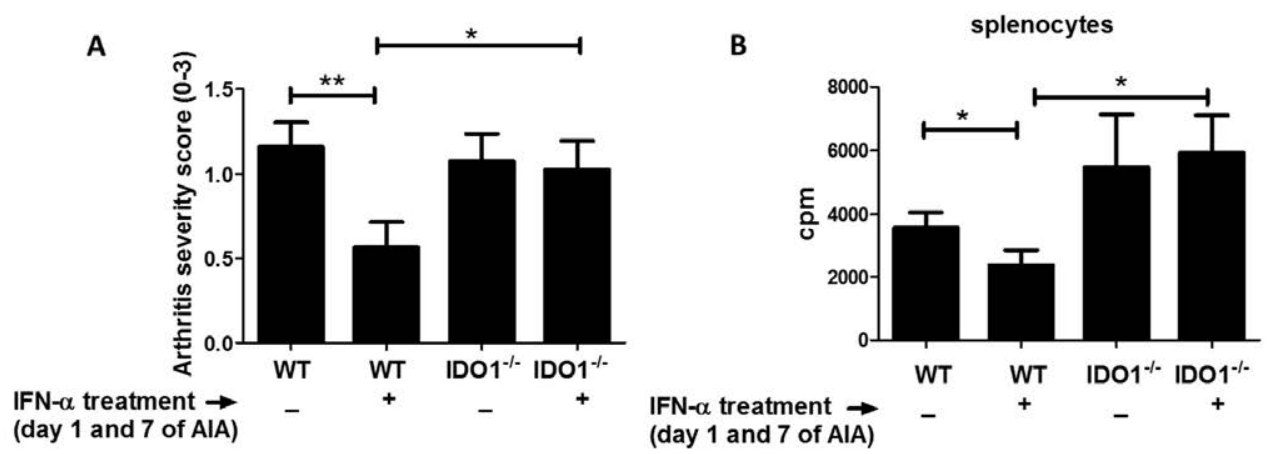

Figure 17: IDO1 expression is required for the protective effect of IFN- $\alpha$. AIA was induced in female Ido1-/and their wild type littermate mice treated with or without $1000 \mathrm{U}$ IFN- $\alpha$ as described in Methods. (A) The level of arthritis evaluated at day 28 of AIA is expressed as severity score (mean \pm SEM, $\mathrm{n} \geq 16$ ) from Ido1-/- mice and their WT littermates. (B) Splenocytes from day 28 of AIA were re-stimulated ex vivo with $50 \mu \mathrm{g} / \mathrm{ml}$ of mBSA for $72 \mathrm{hrs}$ and pulsed with radioactive thymidine for the last $20 \mathrm{hrs}$. The incorporated radioactivity (cpm-value) was determined by a beta counter. From the expressed values (mean cpm \pm SEM, $n=\geq 6$ ), the radioactivity (cpm) of the corresponding mock (medium) stimulation was subtracted. Comparison of arthritis severity score and cpm values for proliferation between different treatment groups was done by the Mann Whitney $\mathrm{U}$ test $(* \mathrm{p}<0.05, * *$ $\mathrm{p}<0.001)$. 


\section{The enzymatic activity of IDO1 in IFN- $\alpha$ mediated protection in AIA:}

IDO1 exerts its immune-regulatory activity via its enzymatic or signalling mechanisms. We used 1-MT, a compound which inhibits enzymatic activity of IDO1 to evaluate if enzymatic activity of IDO1 is involved in IFN- $\alpha$ mediated protection in AIA. We administered 1-MT continuously either orally through 1-MT in drinking water solution (day 0-day 28 or day 2028) or via sustained-release 1-MT pellets surgically inserted s.c. (day 0-28) into mice treated with or without IFN- $\alpha$. Regardless of route of administration, mice receiving 1-MT (day 0-28) were not protected by IFN- $\alpha$ treatment and the IFN- $\alpha$-induced anti-proliferative effect was also hampered (Fig. 18). Hence, this proved that enzymatic activity of IDO1 is required for IFN- $\alpha$ mediated protection.

We then questioned the timing of IDO1 expression to antigen sensitization for IFN- $\alpha$ mediated protection. As mentioned earlier, IFN- $\alpha$ treatment is crucial during antigen sensitization for its protection against AIA [111]. Therefore, to also investigate the requirement of enzymatic activity of IDO1 for IFN- $\alpha$ mediated protection during the arthritis phase, we administered 1-MT from day 21-28 of AIA. Under these circumstances, the enzymatic activity of IDO1 is active in the sensitization phase but not in the arthritis phase. Blocking IDO1 during the arthritis phase did not affect IFN- $\alpha$ mediated protection against AIA and the IFN- $\alpha$-induced anti-proliferative effect (Fig. 18). Together these two observations indicate that IFN- $\alpha$ mediated protection and anti-proliferative effect was dependent on the enzymatic activity of IDO1 in the sensitization phase but not in the arthritis phase. Thus, once enzymatic activity of IDO1 is activated, it induces an immunoregulatory state, that weeks later results in down modulation of antigen-induced arthritis and antigenspecific proliferation independently of presence of IDO1 activity.
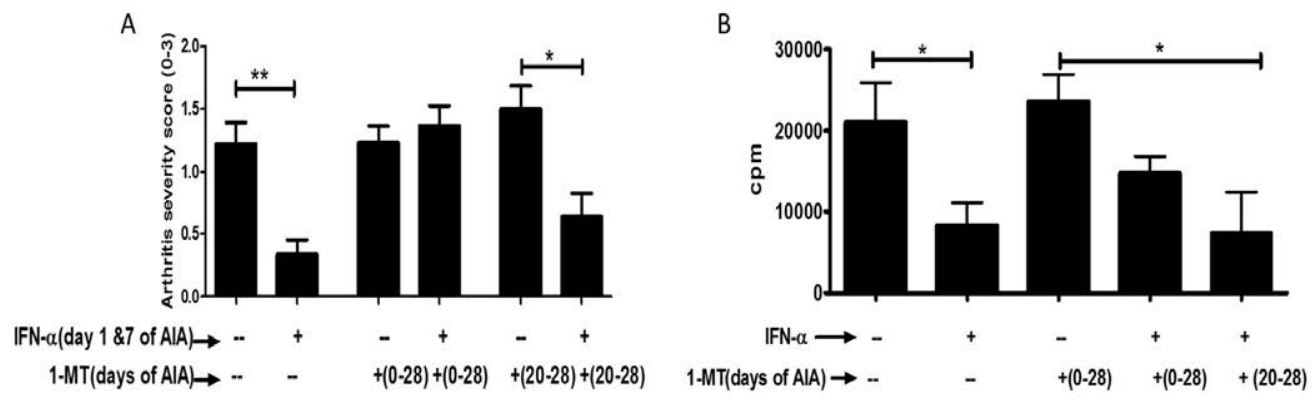

Figure 18: The enzymatic activity of IDO1 is required for the protective effect of IFN- $\alpha$ in the sensitisation but not in the disease onset phase. Female mBSA-sensitized mice treated with or without IFN- $\alpha$ were 
subjected to AIA as described in Methods. To inhibit the enzymatic activity of IDO1, 1-MT was administered by surgical insertion of a 1-MT pellet at day -1 to day 28 or day 20-28 of AIA. A) The level of arthritis expressed as severity score (mean \pm SEM, $n \geq 7$ ) from WT mice that received 1-MT or vehicle and with or without IFN- $\alpha$ treatment. B) Splenocytes from WT mice at day 28 of AIA were re-stimulated ex vivo with $50 \mu \mathrm{g} / \mathrm{ml}$ of $\mathrm{mBSA}$ for $72 \mathrm{~h}$ and pulsed with radioactive thymidine for the last $20 \mathrm{~h}$. The radioactivity (cpm-value) was determined by a beta counter. From the expressed values (mean $\mathrm{cpm} \pm \mathrm{SEM}, \mathrm{n} \geq 7$.) the radioactivity $(\mathrm{cpm})$ of the corresponding mock (medium) stimulation was subtracted. Comparison of arthritis severity score and cpm values for proliferation between groups was done by the Mann Whitney $U$ test $(* p<0.05, * * p<0.001)$.

\section{The enzymatic activity of IDO1 acts upstream of TGF- $\beta$ signalling in the sensitization phase.}

As both TGF- $\beta$ and enzymatic activity of IDO1 were required during sensitization for IFN- $\alpha$ mediated protective effect in AIA, we therefore, investigated if IFN- $\alpha$-induced induction of enzymatic activity of IDO1 was dependent on TGF- $\beta$ expression or if IFN- $\alpha$-induced TGF- $\beta$ expression was dependent on enzymatic activity of IDO1. To study if IFN- $\alpha$-induced induction of enzymatic activity of IDO1 was dependent on TGF- $\beta$ expression, we measured enzymatic activity of IDO1 by blocking TGF- $\beta$. Kyn/Trp levels were not affected when we administered anti-TGF- $\beta$ antibodies in the sensitization phase (day 0-8) of mice receiving IFN- $\alpha$ and were comparable to mice receiving IFN- $\alpha$ only (Fig. 19A). Ex vivo re-stimulation of splenocytes with $\mathrm{mBSA} \pm \mathrm{IFN}-\alpha$ with or without anti-TGF- $\beta$ antibodies demonstrated that blocking TGF- $\beta$ did not affect the expression of IDO1 mRNA. Likewise, a study demonstrated that IFN- $\gamma$-induced activation of enzymatic activity of IDO1 independently of TGF- $\beta[156]$.
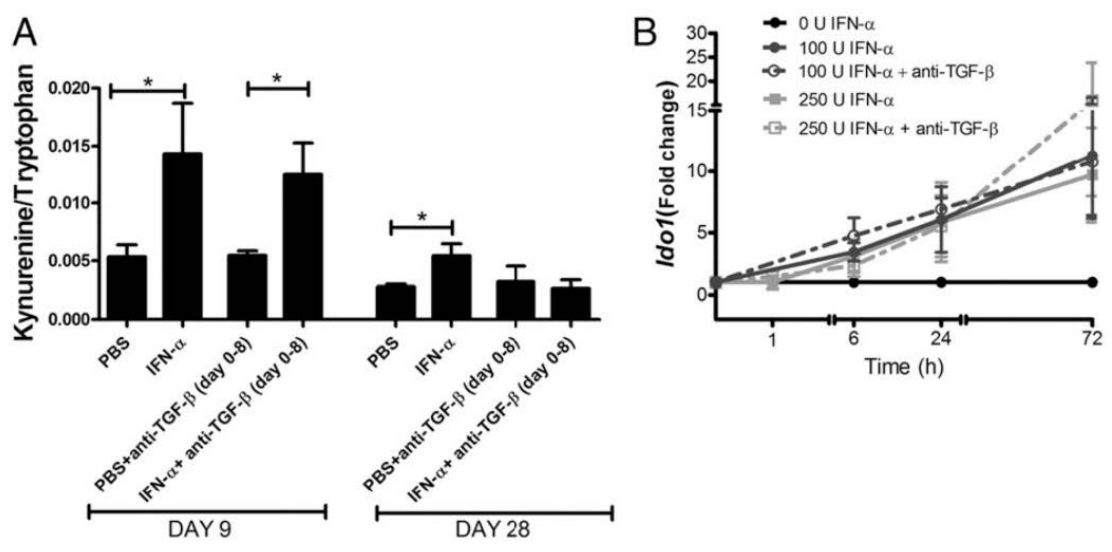

Figure 19. IFN- $\alpha$-induced activation of IDO1 in the sensitization phase of AIA and in vitro occurs independently of TGF- $\boldsymbol{\beta}$. Female mBSA-sensitized mice treated with or without IFN- $\alpha$ treatment, with or without anti-TGF- $\beta$ Abs administered i.p. days $1-8$ as in Fig. 1 and as described for AIA in Materials and Methods. (A) Sera were collected at days 9 and 28 and analyzed for Trp and Kyn concentration by HPLC. Data 
are expressed as the ratio of serum levels of Kyn to Trp, $n \geq 7$. Comparisons between groups were made by Mann-Whitney U test. (B) Splenocytes isolated day 10 from mBSA-sensitized mice were re-stimulated ex vivo with $50 \mathrm{mg} / \mathrm{ml} \mathrm{mBSA}$ with or without $100 \mathrm{U} / \mathrm{ml} \mathrm{IFN-a,} \mathrm{with} \mathrm{or} \mathrm{without} 40 \mathrm{mg} / \mathrm{ml}$ anti-TGF- $\beta$.Data are expressed as fold change normalized to the reference gene Actb and Idol expression in mBSA-stimulated cultured cells from the same mice, $\mathrm{n}=5$. Paired Student $\mathrm{t}$ test was used to evaluate differences between treatments. ${ }^{*} \mathrm{p}<0.05$.

Next we investigated whether IFN- $\alpha$-induced TGF- $\beta$ expression was dependent on enzymatic activity of IDO1. We measured serum TGF- $\beta$ levels in mice in which the enzymatic activity of IDO1 was blocked using 1-MT. As observed earlier [112], mice treated with IFN- $\alpha$ during immunizations displayed significantly higher levels of TGF- $\beta$ levels in serum. However, upon treatment with 1-MT, this incremental effect on TGF- $\beta$ was diminished (Fig. 20A). Further, the observed reduction of TGF- $\beta$ protein levels was also confirmed at mRNA level on day 10 of AIA (Fig 20B). Ex vivo re-stimulation of splenocytes with $\mathrm{mBSA} \pm \mathrm{IFN}-\alpha$ with or without 1-MT treatment, also showed reduction of IFN- $\alpha$-induced TGF- $\beta$ levels in the presence of 1 MT (Fig. 20C). This was confirmed at mRNA level from the same cultures (Fig. 20D).
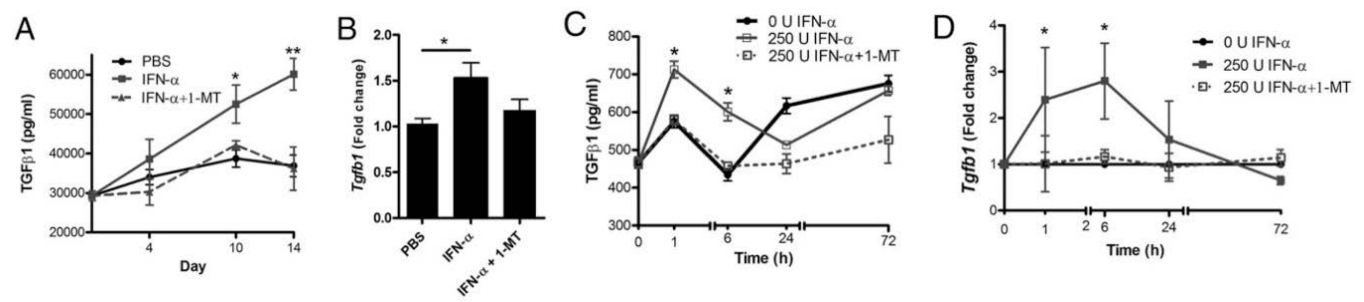

Figure 20. The enzymatic activity of IDO1 regulates IFN- $\alpha$-induced TGF- $\beta$ production in vivo and in vitro. (A and B) mBSA-sensitized mice treated with or without IFN- $\alpha$, with or without 1-MT administered in drinking water, as described for AIA in Materials and Methods. Levels of TGF- $\beta$ in serum were determined by ELISA at the indicated time points during sensitization phase (A), and TGF- $\beta$ mRNA levels in spleens were determined by RT-PCR at day 10 (B). For in vitro studies, splenocytes isolated day 10 from mBSA-sensitized mice were re-stimulated ex vivo with $50 \mathrm{mg} / \mathrm{ml} \mathrm{mBSA}$ with or without $250 \mathrm{U}$ IFN- $\alpha$, with or without $5 \mathrm{mM} 1$ MT. Depicted in (C) are the levels of TGF- $\beta$ in culture supernatants determined by ELISA, and in (D) the TGF- $\beta$ mRNA levels in cultures cells as determined by RT-PCR at the indicated time points. In (D), data are expressed as fold change normalized to reference gene $A c t b$ and $T g f \beta$ expression in mBSA-stimulated cultured cells from the same mice. Comparison of TGF- $\beta$ levels between groups in vivo $(A, n=8 ; B, n<5)$ was done by the MannWhitney $U$ test and in vitro $(C$ and $D, n=5)$ by Student $t$ test for paired observations $\left({ }^{*} p<0.05, * * p<0.01\right)$.

\section{Kyn, the major IDO1 product, ameliorates arthritis:}

Kyn is the major metabolic product of IDO1 mediated catabolism of Trp and is known to exhibit anti-inflammatory effects in vivo [221]. IFN- $\alpha$-induced enhanced turnover of Trp to Kyn prompted us to probe the ability of Kyn to down modulate AIA independently of IFNAR signalling. We administered Kyn $15 \mathrm{mg} / \mathrm{kg}$ during immunizations at day 1 and 7 . Treatment with Kyn significantly reduced arthritis severity while compared to mice that did not receive 
Kyn (Fig. 21).

As Kyn is a downstream product of IFN- $\alpha$ signalling and since IDO1 signalling can induce long term immunoregulatory effects via IDO1 mediated production of IFN- $\alpha$ [156], we investigated whether the protective effect of Kyn against AIA was downstream or upstream of type I IFN signalling. Mice lacking the type I IFN receptor (IFNAR ${ }^{-/}$) treated with Kyn were protected equally as WT mice that received Kyn during immunization (Fig. 21). In conclusion, protection induced by Kyn against AIA was independent of endogenous type I IFN signalling.

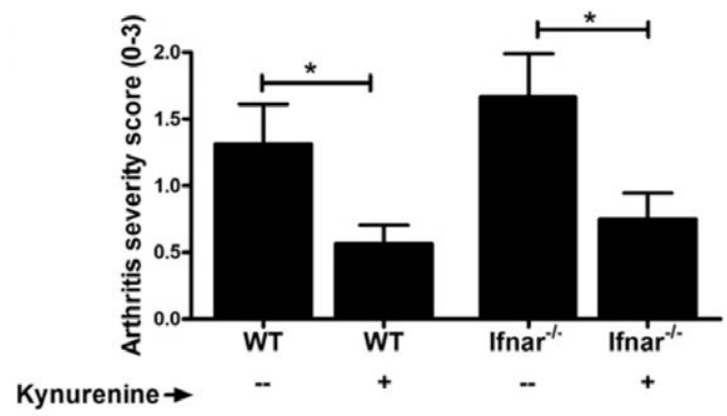

Figure 21. Kyn, the major IDO1 product, ameliorates arthritis. AIA was induced in WT or IFNARKO female mice as described in Methods. Mice were treated with or without Kyn ( $15 \mathrm{mg} / \mathrm{kg}$ mouse weight) during sensitisation of AIA. The level of arthritis is expressed as severity score (mean \pm SEM, $n \geq 7$ ). Comparison of arthritis severity score between groups was done by the Mann Whitney U test $(* \mathrm{p}<0.05)$.

The protective effect of IFN- $\alpha$ in AIA requires presence of pDC both in the sensitization and arthritis phase.

pDCs are an important source of IDO1 which is activated by IFN- $\alpha$ [156]. We did not find any significant difference at day 4 in IDO1 gene expression in pDC from spleens of animals that received IFN- $\alpha$ or PBS (refer to fig. 7 in paper III). However, there was 8 fold upregulation of IDO1 gene expression at day 28 in pDC from IFN- $\alpha$ treated animals. IDO1 gene upregulation was confirmed by western blot analysis of IDO1 protein in pDC. Supporting $\mathrm{pDC}$ as a primary source for IDO1, in vivo depletion of $\mathrm{pDC}$ from IFN- $\alpha$ treated animals decreased the IDO1 protein expression in spleens (data not shown). We then questioned if $\mathrm{pDCs}$ are crucial for IFN- $\alpha$ mediated protection against AIA. We depleted pDC in the sensitization phase or the arthritis phase as described in the methods section. Depletion of pDC completely abolished IFN- $\alpha$ mediated protection in both the sensitization phase and arthritis phase (Figure 22). These phases are mechanistically different in the sense that the 
protective effect of IFN- $\alpha$ is mediated by IDO1 and TGF- $\beta$ in the sensitization phase and conversely, these factors are redundant for the protective effect of IFN- $\alpha$, after arthritis is triggered by intra-articular injection of mBSA. Similar to our finding, a number of studies have demonstrated anti-inflammatory effect and protective effect of IDO1-expressing pDC in atherosclerosis [222], EAE [223] and HIV[224]. We do not know the significance of IDO expression by $\mathrm{pDC}$ in the arthritis phase. There is also a non-enzymatic signalling provided by IDO1 but we have not found the evidence for this in IFN- mediated protection against AIA [113]. Taken together, IDO1-expressing pDC may have different roles in both phases for IFN- $\alpha$ mediated protection against AIA.

We have shown that IFN- $\alpha$ treatment during sensitization induces expression of IDO1 in pDC both in vivo and in vitro (Refer to Fig. $8 \mathrm{C}$ in paper III). IDO1 and IDO1 expressing pDC are known to induce Foxp3 expression in T cells and development of regulatory T cells [131, 225, 226]. We speculated that IDO1 expressing pDC contributes to IFN- $\alpha$ mediated protective effect against AIA and mBSA-specific anti-proliferative by promoting induction of Tregs. pDC via type I IFN signalling can induce Tregs [227] and enzymatic activity of IDO1 is required for $\mathrm{pDC}$-induced Treg induction [228]. IDO1 expressing $\mathrm{pDC}$ can activate the AhR receptor on T cells via generation of Kyn, which skews the development of T cells towards Foxp $3^{+}$Tregs [174]. IDO1-induced expression of TGF- $\beta$ (Fig. 20) could also contribute to the development of Foxp $3^{+}$Tregs [229]. Therefore, we evaluated the importance of Tregs for the protection conferred by IFN- $\alpha$. Given the fact that IDO1 expressing pDC (which generates Kyn) and TGF- $\beta$ expression are required in the sensitization phase for protection mediated by IFN- $\alpha$ against AIA, we believe that these factors aid in the development of Tregs that suppress inflammation. Once generated, Tregs inhibit arthritis independently of IDO1 and TGF- $\beta$ signalling which are redundant in arthritis phase. 


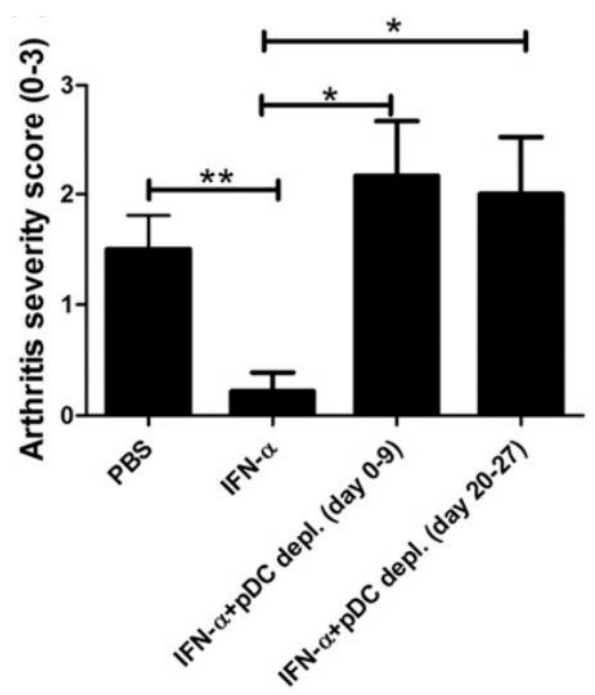

Figure 22. The protective effect of IFN- $\alpha$ in AIA requires the presence of pDC both in the sensitization and arthritis phase. AIA was induced in female mice with IFN- $\alpha$ treatment as described in Materials and Methods, with or without daily injections of the pDC-depleting antibody, $120 \mathrm{G} 8$ from day 0-8 (sensitization phase) or day 20-27 (arthritis phase). (A) The level of arthritis is expressed as severity score (mean 6 SEM, $n \geq 6$ ). Comparison between groups was made by Mann-Whitney U test. ${ }^{*} \mathrm{p}<0.05,{ }^{*} \mathrm{p}<0.01$.

\section{Regulatory $T$ cells manifest IFN- $\alpha$ mediated protection during antigen-induced arthritis} (Paper IV).

\section{Regulatory $T$ cells mediate the IFN- $\alpha$-protection against AIA.}

We have earlier shown that IDO1 mediates protection by IFN- $\alpha$ against AIA [113] and could be involved in induction of Tregs. Here, we investigated if the protection conferred by IFN- $\alpha$ in AIA was dependent on Tregs. In order to study this, we utilized DEREG mice where Foxp $3^{+}$Tregs can be depleted transiently in vivo two days after administration of DT (Treg repopulate to normal percentage in 7-10 days). DT was administered at day -1 or 5 or 19 during AIA and the effect of Treg depletion in IFN- $\alpha$ treated DEREG and non-treated DEREG mice was evaluated on day 28. When Tregs were depleted during sensitization (around day 1 or 7), IFN- $\alpha$ was still able to render its protection against AIA. However, when Tregs were depleted during induction of arthritis (day 21), the protective effect of IFN- $\alpha$ was completely abolished (Fig.23). This indicates that Tregs are crucially required for IFN- $\alpha$-protection in the arthritis phase but redundant during the sensitization phase. In a recent study, it was shown that immunized mice treated with MOG-IFN- $\beta$, prevented EAE by generation of MOG-specific Tregs and depletion of these Tregs abrogated the IFN- $\beta$-induced protective effect [230]. 
A.

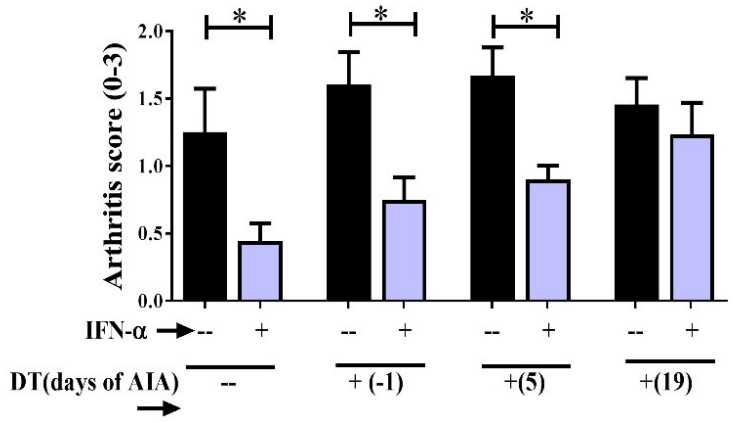

B.

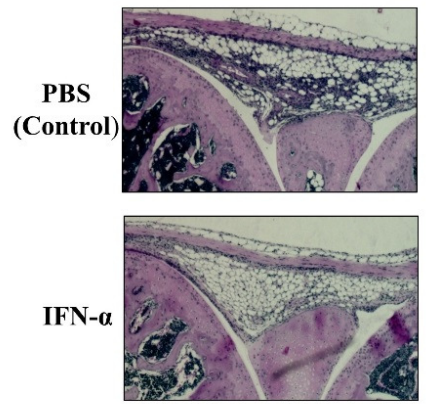

Figure 23. Regulatory $\mathbf{T}$ cells mediate the IFN- $\alpha$-protection against AIA. AIA was induced in female Foxp $3 D T R e G F P^{+/}$or their wild type littermates Foxp3DTReGFP $P^{-/}$with or without $1000 \mathrm{U}$ IFN- $\alpha$ as described in methods. DT was administered i.p at day -1 or 5 or 19 of AIA for transient depletion of Foxp $3^{+}$Tregs. A) The level of arthritis evaluated at day 28 of AIA is expressed as severity score (mean $\pm \mathrm{SEM}, \mathrm{n} \geq 7$ ). Comparison of arthritis severity score between different IFN- $\alpha$ treated and non-treated groups was done by the Mann Whitney U test $(* p<0.05)$. B) Representative histochemical slides depicting arthritis severity score from control group (score-1) and IFN- $\alpha$ treated group (score-0) from wild type mice.

\section{IFN- $\alpha$ treatment in vivo increases the in vitro suppressive activity of regulatory $\mathrm{T}$ cells.}

We have demonstrated that Tregs were essential for IFN- $\alpha$-protection in the arthritis phase, we therefore questioned if this protection was associated with an increase in Tregs in vivo in IFN- $\alpha$-treated mice. We analysed the percentage of Foxp $3^{+}$Tregs among CD4 ${ }^{+} \mathrm{T}$ cells at different time points in AIA from blood, spleens and draining LNs of IFN- $\alpha$-treated or control mice. We did not observe any significant difference in the percentages of Tregs in blood, spleens and draining LNs of IFN- $\alpha$-treated vs control mice, although a trend of increased Tregs was observed in spleens and LNs of IFN- $\alpha$-treated mice after arthritis induction (Refer to figure $2 \mathrm{~A}$ in paper IV). One mechanism by which IFN- $\alpha$ treatment could influence Tregs without affecting the number of Tregs is by enhancing their suppressive activity. Hence, we tested the ex vivo suppressive capacity of Tregs isolated (spleens and draining LNs) from IFN- $\alpha$ or PBS treated mice at day 4, 10, 20 and 28 of AIA. A CFSE-based suppression assay was performed as mentioned in detail in the methods section. In brief, 50000 CFSE-stained T responders $\left(\mathrm{CD}^{+} \mathrm{CD} 25^{-}\right)$were co-cultured with irradiated APCs and decreasing number of Tregs $\left(\mathrm{CD} 4^{+} \mathrm{CD} 25^{+ \text {high }}\right)$ in the presence of mBSA or anti-CD3 for 72 hours. There was no significant difference in the suppressive capacity of Tregs isolated at day 4 from PBS or IFN$\alpha$-treated mice (Fig. 24). We observed a significantly higher suppression of antigen-induced proliferation of Tresponders by Tregs isolated at day 10, 20 and 28 from IFN- $\alpha$-treated mice 
while compared to Tregs from control mice (Fig. 24 top panel). However, from day 20 and onwards, Tregs isolated from IFN- $\alpha$-treated mice were quite efficient in supressing polyclonal stimulation (anti-CD3) of Tresponders (Fig. 24 bottom panel). Taken together, this data suggests that IFN- $\alpha$ treatment makes Tregs more efficient in suppressing proliferation of antigen-specific T cells day 10 onwards. Surprisingly, from day 20 and onwards, Tregs from IFN- $\alpha$-treated mice were also efficient in suppressing polyclonally induced proliferation of Tresponders. The effects of type I IFNs on the generation and suppressive capacity of Tregs is controversial [123] as some studies show an inhibitory effect on Treg function [133] while other studies including ours demonstrate augmented effect of IFN- $\alpha$ on Tregs $[123,230]$. Wang et al clearly demonstrated antigen-specific increase in Tregs (both in vivo and in vitro) in MOG-specific transgenic immunized mice treated with MOG+IFN- $\beta$ in alum where animals were protected against EAE [230]. In the mentioned study, a majority of T cells were MOG specific. We did not observe a similar effect in vivo probably due to a low proportion of mBSA-specific $\mathrm{T}$ cells among total $\mathrm{CD}^{+} \mathrm{T}$ cells to elicit robust development of antigenspecific Tregs. Even though we did not observe a significant increase in Tregs numbers in vivo, tregs isolated from IFN- $\alpha$-treated mice were potentially more efficient at supressing antigen-spcific proliferation than Tregs from control mice.
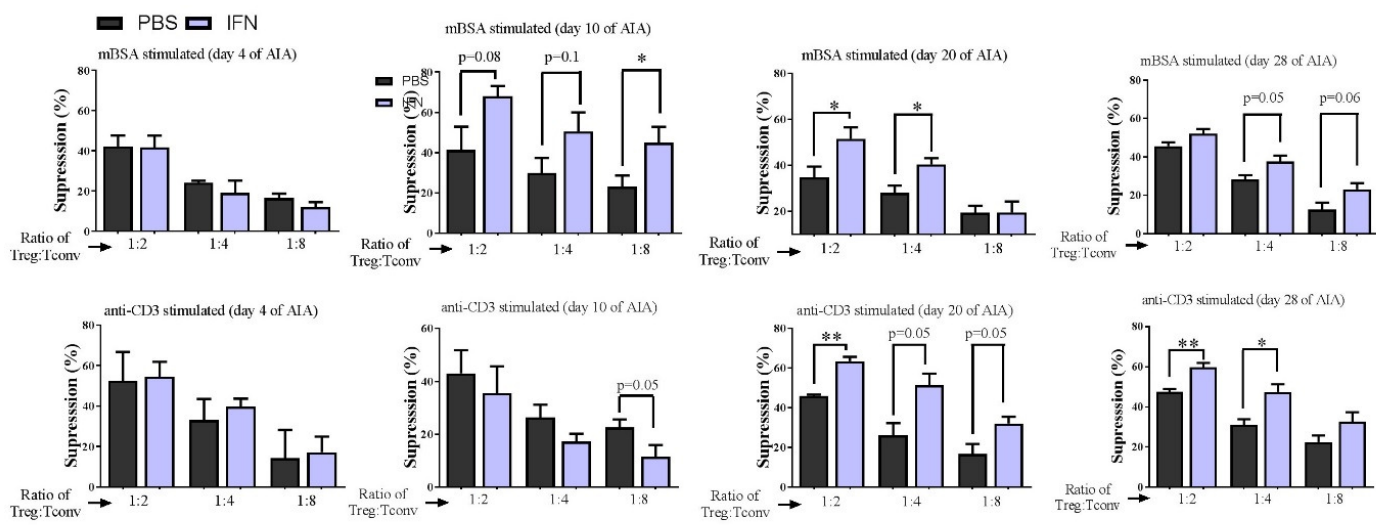

Figure 24. IFN- $\alpha$ treatment in vivo increases the in vitro suppressive activity of regulatory $\mathbf{T}$ cells. Percent suppression by Tregs $\left(\mathrm{CD} 4^{+} \mathrm{CD} 25^{\text {thigh }}\right)$ isolated from PBS or IFN- $\alpha$ treated mice at day 4, 10, 20 and 28 against proliferation of Tresp cells ( $\mathrm{CD} 4^{+} \mathrm{CD} 25^{-}$from untreated mice) isolated the same days of AIA and stimulated with mBSA (top) or anti CD3 (bottom). Suppression against proliferation of Tresp cells by Tregs at decreasing $\mathrm{T}_{\text {reg }}: \mathrm{T}_{\text {resp }}$ cell ratios after $72 \mathrm{~h}$ culture was calculated as described in methods. Student $\mathrm{t}$ test was used to compare differences between groups. $* \mathrm{p}<0.05), * * \mathrm{p}<0.01) . \mathrm{n}=\geq 5$. 


\section{Type I IFN signalling in T helper cells is not required for IFN- $\alpha$ protection against AIA.}

Next, we wanted to investigate if protection by IFN- $\alpha$ is a direct effect on T helper cells. To study this, we used CD4-Cre ${ }^{+/-}$IFNAR flox/flox mice in which the IFN- $\alpha$ receptor (type I IFN receptor) is knocked out specifically in $\mathrm{CD}^{+} \mathrm{T}$ cells. We observed that mice lacking type I IFN receptor on $\mathrm{CD}^{+} \mathrm{T}$ cells treated with IFN- $\alpha$ were equally protected against AIA while compared to IFN- $\alpha$-treated WT counterpart (Fig. 25). Considering that depletion of Tregs in the sensitization phase did not abrogate the protection rendered by IFN- $\alpha$, we speculate that IFN- $\alpha$ acts on a cell population other than $\mathrm{CD}^{+} \mathrm{T}$ cells during antigen sensitization to render its protective effect against AIA. In one study, type I IFN has been shown to have a transient and direct inhibitory effect on Tregs in a model of acute viral infection [133]. This inhibitory effect was necessary to mount an optimal anti-viral response and was dependent on IFNAR. On the contrary, protection by IFN- $\alpha$ mediated by Tregs is not dependent on type I IFN signalling in T cells suggesting the enhancing effect of IFN- $\alpha$ on Tregs is an indirect effect.

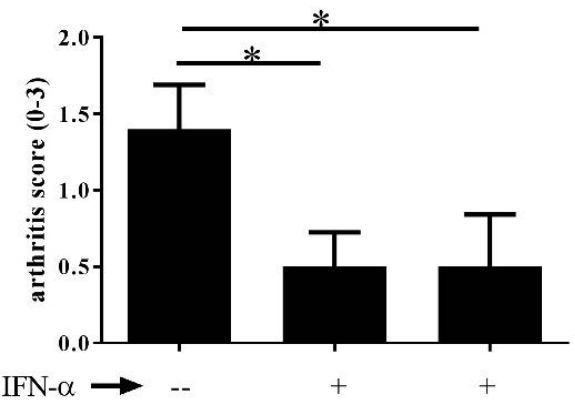

Blocking of IFN- $\alpha$

signalling on CD4+ cells

Figure 25. Type I IFN signalling in T helper cells is not required for IFN- $\alpha$-protection against AIA. AIA was induced in female CD4-Cre ${ }^{+/-}$IFNAR flox/flox mice or their wild type littermates CD4-Cre ${ }^{-/}$IFNAR flox/flox mice with or without $1000 \mathrm{U}$ IFN- $\alpha$ as described in methods. The level of arthritis evaluated at day 28 of AIA is expressed as severity score (mean $\pm \mathrm{SEM}, \mathrm{n} \geq 7$ ). Comparison of arthritis severity score between different IFN- $\alpha$ treated and non-treated groups was done by the Mann Whitney U test $(* \mathrm{p}<0.05)$.

\section{Enzymatic IDO activity mediates the increased suppressive capacity of Tregs conferred by IFN- $\alpha$.}

Previously, we have demonstrated that IFN- $\alpha$ enhances enzymatic activity of IDO1, which was critically required in the sensitization phase for IFN- $\alpha$ protective effect and also $\mathrm{pDC}$ that have been shown to express IDO1 (Refer to Fig. 8 in paper III) were essential for IFN- $\alpha$ mediated protection [32]. Because IDO1 is known to induce Tregs, we wanted to test if IDO1 was associated with the observed increase in suppressive capacity conferred by IFN- $\alpha$ on 
Tregs during AIA (Fig. 24). We performed an ex vivo suppressive assay with Tregs from IFN$\alpha$-treated mice in which IDO1 was blocked using 1-MT in the sensitization phase as described above.

The increased suppressive capacity rendered by IFN- $\alpha$ treatment on Tregs was clearly down modulated when IFN- $\alpha$-treated mice received 1-MT during the sensitization phase (Fig. 26). This effect was observed both in Tregs isolated during the sensitization phase (day 10) and also in Tregs isolated after induction of arthritis (day 28).

As mentioned earlier, protection mediated by IFN- $\alpha$ is critically dependent on IDO1 and IDO1 expressing pDCs in the sensitization phase and inhibition of IDO1 abolishes IFN- $\alpha$ induced anti-proliferation. Given that the IDO1 is expressed by pDCs and because the IDO1 inhibitor 1-MT abolished the suppressive capacity of Tregs confer by IFN- $\alpha$, we believe that IDO1 expressing pDC play a crucial role in the induction of such suppressive Tregs. In fact, IDO1 expressing pDC were shown to induce potent Tregs which suppressed development of EAE [221].

$\square$ PBS $\square$ IFN- $\square \quad \square$ 1-MT + IFN- $\alpha$
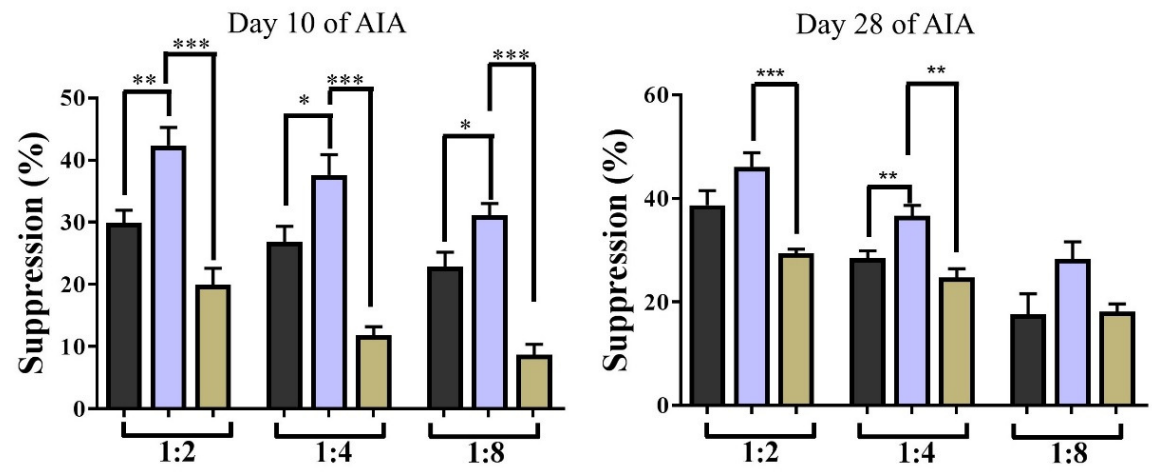

Figure 26. Enzymatic IDO activity mediates the increased suppressive capacity of Tregs conferred by IFN$\boldsymbol{\alpha}$. Tregs $\left(\mathrm{CD} 4^{+} \mathrm{CD} 25^{\text {thigh }}\right)$ from mice treated with IFN- $\alpha$ with or without 1-MT treatment (during sensitization phase as described in [113] and Tresp cells, (CD4 $\left.{ }^{+} \mathrm{CD} 25^{-}\right)$from non-treated mice was isolated at day 10 , and 28 of AIA. Percent suppression by Tregs isolated from PBS, IFN- $\alpha$, IFN- $\alpha+1-$ MT treated mice at day 10 and 28 against proliferation of Tresp cells (from untreated mice) isolated the same days of AIA and stimulated with mBSA. Student $t$ test was used to compare suppressive capacity between groups. $* \mathrm{p}<0.05), * * \mathrm{p}<0.01)$, *** $\mathrm{p}<0.001$ ). 


\section{Adoptive transfer of Tregs from mBSA immunized mice protects against mBSA-induced arthritis.}

Granted that IFN- $\alpha$ treatment in vivo enhanced the ex vivo suppressive capacity of Tregs, we investigated the ability of Tregs from IFN- $\alpha$-treated mice to protect against mBSA-induced arthritis. We isolated Tregs $\left(\mathrm{CD} 4^{+} \mathrm{CD} 25^{\text {thigh }}\right)$ from mBSA-sensitized mice treated or not treated with IFN- $\alpha$ at day 20 of AIA. 50000 Tregs were administered intravenously to mBSA-sensitized recipient mice subjected to AIA on day 20. The next day, arthritis was induced by intra-articular injection of mBSA and arthritis severity was evaluated at day 28 . Transfer of 50000 Tregs from IFN- $\alpha$-treated mice clearly down modulated development of arthritis compared to same number of Tregs from PBS treated mice (Fig. 27).

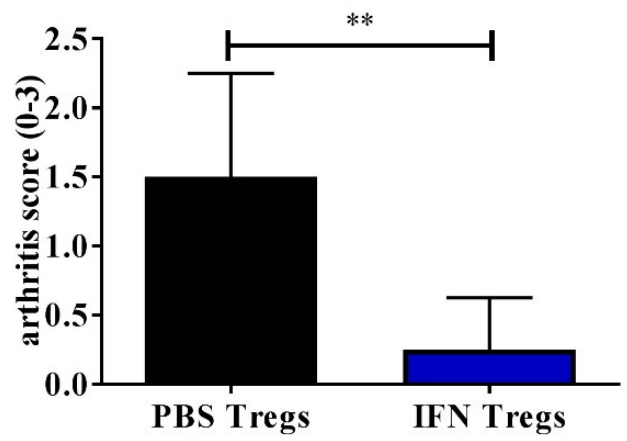

Figure 27. Adoptive transfer of Tregs from mBSA immunized mice protects against mBSA induced arthritis. Spleens and draining lymph nodes from PBS and IFN- $\alpha$ treated mice undergoing AIA were collected at day 20 of AIA. 50000 Tregs $\left(\mathrm{CD}^{+} \mathrm{CD} 25^{\text {thigh }}\right)$ were sorted using FACS and were injected intravenously in pre-sensitized recipient mice on day 20. These recipient mice were subjected to arthritis induction on day 21 . Comparison of arthritis severity score between pre-sensitized recipient mice receiving either Tregs from PBS or IFN- $\alpha$ treated mice was done by the Mann Whitney $U$ test $(* p<0.05),(n=6)$.

In conclusion, we show that presence of IFN- $\alpha$ during the sensitization phase aids in generation of efficient antigen-specific Tregs that can be used as a tolerogenic treatment modality for treating autoimmune diseases. 


\section{Summary and Conclusion}

Extensive research is needed to develop new methods or novel drugs to treat RA. Current treatment modalities only provide symptomatic and transient relief. Uridine is a novel candidate drug that can be used to treat autoimmune diseases. In paper I, we showed that local administration of uridine had a down modulatory effect on the development of AIA in a dosedependent manner. This anti-inflammatory effect did not include alteration of the systemic immune response to mBSA but was associated primarily with suppressed expression of synovial adhesion molecules and secondarily to the inhibition of synovial influx of inflammatory leukocytes and synovial expression of pro-inflammatory cytokines. Uridine can also be used to develop topical or local applications to treat autoimmune disorders like psoriasis.

Another approach to treat autoimmune diseases is by inducing long term immune tolerance whereby the immune system is educated not to attack self. Type I IFNs are pleotropic cytokines that exhibit both pro- and anti-inflammatory properties depending on the context. Here we studied the mechanisms behind pro- and anti-inflammatory properties of type I IFN signalling in experimental arthritis.

In paper II, we showed occurrence of both $\mathrm{pDC}$ and $\mathrm{cDC}$ in the inflamed joint of dsRNAinduced arthritis. Thereafter, we demonstrated that dsRNA-stimulated, Flt3L-derived DCs induced arthritis when injected into a healthy knee joint. This arthritogenicity of dsRNAstimulated DCs was dependent on type I IFN signalling in donor DCs whereas presence of IFNAR in recipient mice was not required. We also show that both $\mathrm{cDC}$ and pDC are arthritogenic when pretreated with dsRNA. Taken together, with this finding we speculate that presence of dsRNA in the synovium post-viral infection can induce arthritis via activation of type I IFN signalling in DCs. This mechanism could be used by both dsRNA and DCs to trigger and drive inflammation in the synovium.

In paper III, we found that the protective effect of IFN- $\alpha$ against antigen-induced arthritis was mediated by both TGF- $\beta$ and IDO1 enzymatic activity in the sensitization phase, whereas these entities were redundant in the arthritis phase for the protective effect of IFN- $\alpha$. IDO1 operates upstream of TGF- $\beta$ signalling and is produced by $\mathrm{pDC}$, which are also crucial for the protection by IFN- $\alpha$. Once activated, IDO1 induced an immunomodulatory state that weeks later brings about suppression of arthritis. Further, we showed that kyn, an enzymatic product of IDO1, mediated protection rendered by IFN- $\alpha$ independently of IFNAR signalling. 
In paper IV, we found that regulatory $\mathrm{T}$ cells were critical for protection conferred by IFN- $\alpha$ in the arthritis phase of AIA. Additionally, treatment with IFN- $\alpha$ enhanced the suppressive capacity of Tregs in an antigen-dependent manner. This enhanced suppressive function of Tregs was dependent on the presence of enzymatic activity of IDO1 during the sensitization phase. Finally, we showed that Tregs from IFN- $\alpha$ treated mice exhibit potent suppressive function against AIA when adoptively transferred to mBSA-sensitized mice subjected to AIA. In this thesis, we also show that uridine is a molecule that can be used to locally limit inflammation. We also describe an anti-inflammatory mechanism of type I IFN signalling that involves immune tolerance which could help to develop antigen-specific therapeutic strategies to treat autoimmune diseases. 


\section{Acknowledgement}

Mattias Magnusson: I would like to thank Mattias, my main supervisor, for giving me an opportunity to do research under your guidance. Your sportive, down to earth and inspiring attitude made me think how I should be in future. I really cherish your friendly nature and during all these years, I never felt any hesitancy to ask you help on professional or personal basis. Now that I am about to hold a PhD in the field of immunology and knowledge I gained during the studies, all the accolade goes to you. "Tack så mycket" for being an excellent supervisor and a fantastic joyful person.

Srinivas Uppugunduri (Co-supervisor): I would like to express my gratitude for your guidance and support during my studies. Your valuable suggestions and help made our life in Sweden very smooth and comfortable. I really like all those family get-togethers we had during all this time.

Alf Kastbom (Co-supervisor): Thanks for your support during my studies. I worked briefly in a research project connected to you, though not included in my thesis, I would like to thank you for being my co-supervisor.

Jaya Prakash Chalise: Well!!! I wonder where to start? We talked, discussed, argued and worked together for so many years. You are a wonderful critic and used to give so many valuable suggestions on professional and personal aspects. I really miss you a lot.

Liv Gröntoft: No words to mention about you. You have been a great friend than a colleague all these years. You have been the most helpful and supportive person and always came forward to help us to any extent. Our short picnics, dinners, funny Christmas gifts are one of the memorable moments in Sweden. Without your expertise and help, I wouldn't have succeeded in performing immunohistochemistry. I acknowledge your effort that you put in preparing the tissue sections for us. I appreciate your immense and unfruitful effort in making me speak Swedish. Thanks for introducing us the concept of "Ekologiska produkter (-)".

Jonas Wetterö: Any kind of problem!!! I used to go to Jonas for his help and guidance. You are so reachable to every student and co-worker. I really thank you for your valuable suggestions regarding my future prospects.

I would like to thank Jan Enerudh, Thomas Skogh and Per Hultman for their encouragement, expertise and kind support during my studies.

Maria Jenmalm: You were my mentor during my master studies and it wouldn't have been possible to get a project under supervision of Mattias Magnusson without your guidance. This was a turning point in my career which led to my studies as a $\mathrm{PhD}$ student. Your immense knowledge in the field of immunology has always been a true inspiration.

Bo Häggqvist: You are a kind, soft spoken friend and a skilful colleague. We had so many wonderful discussions during lunch at AIR. Thank you for your help and support during my studies. You gave so many valuable suggestions about everything in Sweden and especially matters related to car. I appreciate your help with immunohistochemistry.

Hammoudi Alkaissai: You are have been great and joyful friend. Thanks a lot for your help and support during my entire studies. Happy Gaming man!!! 
Said Havarinasab: You are a kind friendly colleague. I really enjoyed all our discussions during lunch at AIR. Thank you your help and suggestions regarding my studies and my personal aspects.

Petra Cassel: I would like to specially thank you for your help regarding administration and laboratory stuff. I appreciate your patience especially in helping me to find things at AIR.

To all student that worked in our group: Erik Ljungren, Emelei Larsson, Hannna Hillman, Emil Rankka, Stina Blom, Giulia Amato and Aida Shalouie. It was nice to work and share knowledge with you all.

Sophie Biggs and Joanitah Namale: You are wonderful friends and brilliant hardworking $\mathrm{PhD}$ aspirants. It was fun to share work space and laboratory work during your studies. I wish you all the best for your future endeavours. @Sophie, thanks for scrutinizing my thesis.

I would like to thank Daniela Patinha, Robert Lindau, Johanna Houman, Linda Fryland, Daniel Eklund, Helena Enocsson, Lina Wirestam, Karin Söderman, Marie Ruber and Klara Martinsson for your nice friendly atmosphere at AIR and your help during all these years.

Florence Sjögren: Thank you for teaching me FACS and helping me with all FACS-related matters.

To all current and previous colleagues at AIR: Marie Malander, Johanna Raffetseder, Camilla Janefjord, Anna Forsberg, Sandra Hellberg, Mari-Anne Åkesson, Judit Svensson-Arvelund, Ylva Billing, Christer Bergman, Ann-Marie Fornander, Gunnel Almroth and martina Abelius. Thank you all for your help in different matters over the years.

To all my friends Raghava, Mayur, Ravi, Miraz, Sandeep, Pratheek, Manish, Sumit, Ratnesh, Mehdi, Phani, Madhu, Cecilia, Elmira and Zaheer. I really had wonderful time with you all. Thanks for being helpful anytime and everytime.

To my family: Thank you Vidya for showing great support, care and love during all these years and many years to come. Without you it wouldn't have been possible. And my little naughty cute Aarav who made by life wonderful. You both are my everything.

To my parents, Nana and Amma my brothers, Shiva, Vishnu and Harsha, thank all you for your constant support, encouragement and unconditional love.

To Sandy: You will always be in my heart. 


\section{References}

[1] McInnes IB, Schett G. The Pathogenesis of Rheumatoid Arthritis. New England Journal of Medicine, 2011;365:2205-19.

[2] Gregersen PK, Silver J, Winchester RJ. The shared epitope hypothesis. an approach to understanding the molecular genetics of susceptibility to rheumatoid arthritis. Arthritis \& Rheumatism, 1987;30:1205-13.

[3] Franssila R, Hedman K. Infection and musculoskeletal conditions: Viral causes of arthritis. Best Pract Res Clin Rheumatol, 2006;20:1139-57.

[4] Bokarewa M, Tarkowski A, Lind M, Dahlberg L, Magnusson M. Arthritogenic dsRNA is present in synovial fluid from rheumatoid arthritis patients with an erosive disease course. European journal of immunology, 2008;38:3237-44.

[5] Hasunuma T, Sumida T, Nishioka K. Human T cell leukemia virus type-I and rheumatoid arthritis. International reviews of immunology, 1998;17:291-307.

[6] Mikuls TR, Payne JB, Yu F, Thiele GM, Reynolds RJ, Cannon GW et al. Periodontitis and Porphyromonas gingivalis in patients with rheumatoid arthritis. Arthritis \& rheumatology (Hoboken, NJ), 2014;66:1090-100.

[7] Malmstrom V, Catrina AI, Klareskog L. The immunopathogenesis of seropositive rheumatoid arthritis: from triggering to targeting. Nat Rev Immunol, 2017;17:60-75.

[8] Makrygiannakis D, Hermansson M, Ulfgren AK, Nicholas AP, Zendman AJ, Eklund A et al. Smoking increases peptidylarginine deiminase 2 enzyme expression in human lungs and increases citrullination in BAL cells. Annals of the rheumatic diseases, 2008;67:1488-92.

[9] Tedeschi SK, Bermas B, Costenbader KH. Sexual disparities in the incidence and course of SLE and RA. Clinical Immunology, 2013;149:211-8.

[10] Silman A, Kay A, Brennan P. Timing of pregnancy in relation to the onset of rheumatoid arthritis. Arthritis and rheumatism, 1992;35:152-5.

[11] Spector TD, Hochberg MC. The protective effect of the oral contraceptive pill on rheumatoid arthritis: an overview of the analytic epidemiological studies using metaanalysis. Journal of clinical epidemiology, 1990;43:1221-30.

[12] van Zeben D, Hazes JM, Vandenbroucke JP, Dijkmans BA, Cats A. Diminished incidence of severe rheumatoid arthritis associated with oral contraceptive use. Arthritis and rheumatism, 1990;33:1462-5.

[13] Brennan P, Bankhead C, Silman A, Symmons D. Oral contraceptives and rheumatoid arthritis: results from a primary care-based incident case-control study. Seminars in arthritis and rheumatism, 1997;26:817-23.

[14] Wilder RL. Adrenal and gonadal steroid hormone deficiency in the pathogenesis of rheumatoid arthritis. The Journal of rheumatology Supplement, 1996;44:10-2.

[15] Karlson EW, Chibnik LB, McGrath M, Chang S-C, Keenan BT, Costenbader KH et al. A prospective study of androgen levels, hormone-related genes and risk of rheumatoid arthritis. Arthritis research \& therapy, 2009;11:R97-R.

[16] Feldmann M, Brennan FM, Maini RN. Role of cytokines in rheumatoid arthritis. Annual review of immunology, 1996;14:397-440.

[17] Alzabin S, Williams RO. Effector T cells in rheumatoid arthritis: lessons from animal models. FEBS letters, 2011;585:3649-59.

[18] Kadowaki KM, Matsuno H, Tsuji H, Tunru I. CD4+ T cells from collagen-induced arthritic mice are essential to transfer arthritis into severe combined immunodeficient mice. Clinical and experimental immunology, 1994;97:212-8. 
[19] Petrow PK, Thoss K, Katenkamp D, Brauer R. Adoptive transfer of susceptibility to antigen-induced arthritis into severe combined immunodeficient (SCID) mice: role of CD4+ and CD8+ T cells. Immunol Invest, 1996;25:341-53.

[20] Keystone E. Treatments no longer in development for rheumatoid arthritis. Annals of the rheumatic diseases, 2002;61 Suppl 2:ii43-5.

[21] van den Berg WB, Miossec P. IL-17 as a future therapeutic target for rheumatoid arthritis. Nat Rev Rheumatol, 2009;5:549-53.

[22] Mottonen M, Heikkinen J, Mustonen L, Isomaki P, Luukkainen R, Lassila O. CD4+ $\mathrm{CD} 25+\mathrm{T}$ cells with the phenotypic and functional characteristics of regulatory $\mathrm{T}$ cells are enriched in the synovial fluid of patients with rheumatoid arthritis. Clinical and experimental immunology, 2005;140:360-7.

[23] van Amelsfort JM, Jacobs KM, Bijlsma JW, Lafeber FP, Taams LS. CD4(+)CD25(+) regulatory $\mathrm{T}$ cells in rheumatoid arthritis: differences in the presence, phenotype, and function between peripheral blood and synovial fluid. Arthritis and rheumatism, 2004;50:2775-85.

[24] Baecher-Allan C, Viglietta V, Hafler DA. Inhibition of human CD4(+)CD25(+high) regulatory $\mathrm{T}$ cell function. Journal of immunology (Baltimore, Md : 1950), 2002;169:6210-7.

[25] Ashley CW, Baecher-Allan C. Cutting Edge: Responder T cells regulate human DR+ effector regulatory $\mathrm{T}$ cell activity via granzyme B. Journal of immunology (Baltimore, Md : 1950), 2009;183:4843-7.

[26] Xiao H, Wang S, Miao R, Kan W. TRAIL is associated with impaired regulation of CD4+CD25- T cells by regulatory $\mathrm{T}$ cells in patients with rheumatoid arthritis. Journal of clinical immunology, 2011;31:1112-9.

[27] Tran CN, Lundy SK, Fox DA. Synovial biology and T cells in rheumatoid arthritis. Pathophysiology : the official journal of the International Society for Pathophysiology, 2005;12:183-9.

[28] Audiger C, Rahman MJ, Yun TJ, Tarbell KV, Lesage S. The Importance of Dendritic Cells in Maintaining Immune Tolerance. The Journal of Immunology, 2017;198:222331.

[29] Mellor AL, Munn DH. IDO expression by dendritic cells: tolerance and tryptophan catabolism. Nat Rev Immunol, 2004;4:762-74.

[30] Pulendran B, Tang H, Manicassamy S. Programming dendritic cells to induce $\mathrm{T}(\mathrm{H}) 2$ and tolerogenic responses. Nat Immunol, 2010;11:647-55.

[31] Kim HJ, Krenn V, Steinhauser G, Berek C. Plasma cell development in synovial germinal centers in patients with rheumatoid and reactive arthritis. Journal of immunology (Baltimore, Md : 1950), 1999;162:3053-62.

[32] Pettit AR, Thomas R. Dendritic cells: the driving force behind autoimmunity in rheumatoid arthritis? Immunology and cell biology, 1999;77:420-7.

[33] Janossy G, Panayi G, Duke O, Bofill M, Poulter LW, Goldstein G. Rheumatoid arthritis: a disease of T-lymphocyte/macrophage immunoregulation. Lancet (London, England), 1981;2:839-42.

[34] Udalova IA, Mantovani A, Feldmann M. Macrophage heterogeneity in the context of rheumatoid arthritis. Nat Rev Rheumatol, 2016;12:472-85.

[35] Chu CQ, Field M, Feldmann M, Maini RN. Localization of tumor necrosis factor alpha in synovial tissues and at the cartilage-pannus junction in patients with rheumatoid arthritis. Arthritis and rheumatism, 1991;34:1125-32.

[36] Lam J, Takeshita S, Barker JE, Kanagawa O, Ross FP, Teitelbaum SL. TNF- $\alpha$ induces osteoclastogenesis by direct stimulation of macrophages exposed to permissive levels of RANK ligand. Journal of Clinical Investigation, 2000;106:1481-8. 
[37] Wright HL, Moots RJ, Edwards SW. The multifactorial role of neutrophils in rheumatoid arthritis. Nat Rev Rheumatol, 2014;10:593-601.

[38] Wittkowski H, Foell D, af Klint E, De Rycke L, De Keyser F, Frosch M et al. Effects of intra-articular corticosteroids and anti-TNF therapy on neutrophil activation in rheumatoid arthritis. Annals of the rheumatic diseases, 2007;66:1020-5.

[39] Brinkmann V, Reichard U, Goosmann C, Fauler B, Uhlemann Y, Weiss DS et al. Neutrophil extracellular traps kill bacteria. Science (New York, NY), 2004;303:15325 .

[40] Wang Y, Li M, Stadler S, Correll S, Li P, Wang D et al. Histone hypercitrullination mediates chromatin decondensation and neutrophil extracellular trap formation. The Journal of cell biology, 2009;184:205-13.

[41] Romero V, Fert-Bober J, Nigrovic PA, Darrah E, Haque UJ, Lee DM et al. ImmuneMediated Pore-Forming Pathways Induce Cellular Hypercitrullination and Generate Citrullinated Autoantigens in Rheumatoid Arthritis. Science Translational Medicine, 2013;5:209ra150-209ra150.

[42] Khandpur R, Carmona-Rivera C, Vivekanandan-Giri A, Gizinski A, Yalavarthi S, Knight JS et al. NETs are a source of citrullinated autoantigens and stimulate inflammatory responses in rheumatoid arthritis. Sci Transl Med, 2013;5:178ra40.

[43] Silverman GJ, Carson DA. Roles of B cells in rheumatoid arthritis. Arthritis research \& therapy, 2003;5:S1.

[44] Edwards JC, Szczepanski L, Szechinski J, Filipowicz-Sosnowska A, Emery P, Close DR et al. Efficacy of B-cell-targeted therapy with rituximab in patients with rheumatoid arthritis. N Engl J Med, 2004;350:2572-81.

[45] Rantapaa-Dahlqvist S, de Jong BA, Berglin E, Hallmans G, Wadell G, Stenlund H et al. Antibodies against cyclic citrullinated peptide and IgA rheumatoid factor predict the development of rheumatoid arthritis. Arthritis and rheumatism, 2003;48:2741-9.

[46] Nielen MM, van Schaardenburg D, Reesink HW, van de Stadt RJ, van der HorstBruinsma IE, de Koning MH et al. Specific autoantibodies precede the symptoms of rheumatoid arthritis: a study of serial measurements in blood donors. Arthritis and rheumatism, 2004;50:380-6.

[47] O'Shea JJ, Ma A, Lipsky P. Cytokines and autoimmunity. Nat Rev Immunol, 2002;2:37-45.

[48] McInnes IB, Schett G. Cytokines in the pathogenesis of rheumatoid arthritis. Nat Rev Immunol, 2007;7:429-42.

[49] Steiner G, Tohidast-Akrad M, Witzmann G, Vesely M, Studnicka-Benke A, Gal A et al. Cytokine production by synovial $\mathrm{T}$ cells in rheumatoid arthritis. Rheumatology (Oxford, England), 1999;38:202-13.

[50] Tetta C, Camussi G, Modena V, Di Vittorio C, Baglioni C. Tumour necrosis factor in serum and synovial fluid of patients with active and severe rheumatoid arthritis. Annals of the rheumatic diseases, 1990;49:665-7.

[51] Mannami K, Mitsuhashi T, Takeshita H, Okada K, Kuzuhara A, Yamashita F et al. Concentration of interleukin-1 beta in serum and synovial fluid in patients with rheumatoid arthritis and those with osteoarthritis. Nihon Seikeigeka Gakkai zasshi, 1989;63:1343-52.

[52] Houssiau FA, Devogelaer J-P, Damme JV, Deuxchaisnes CND, Snick JV. Interleukin6 in synovial fluid and serum of patients with rheumatoid arthritis and other inflammatory arthritides. Arthritis \& Rheumatism, 1988;31:784-8.

[53] Mertens M, Singh JA. Anakinra for rheumatoid arthritis. The Cochrane database of systematic reviews, 2009:Cd005121. 
[54] Schett G, Dayer J-M, Manger B. Interleukin-1 function and role in rheumatic disease. Nat Rev Rheumatol, 2016;12:14-24.

[55] Bettelli E, Carrier Y, Gao W, Korn T, Strom TB, Oukka M et al. Reciprocal developmental pathways for the generation of pathogenic effector TH17 and regulatory T cells. Nature, 2006;441:235-8.

[56] Genovese MC, Braun DK, Erickson JS, Berclaz PY, Banerjee S, Heffernan MP et al. Safety and Efficacy of Open-label Subcutaneous Ixekizumab Treatment for 48 Weeks in a Phase II Study in Biologic-naive and TNF-IR Patients with Rheumatoid Arthritis. J Rheumatol, 2016;43:289-97.

[57] Genovese MC, Durez P, Richards HB, Supronik J, Dokoupilova E, Aelion JA et al. One-year efficacy and safety results of secukinumab in patients with rheumatoid arthritis: phase II, dose-finding, double-blind, randomized, placebo-controlled study. J Rheumatol, 2014;41:414-21.

[58] Genovese MC, Durez P, Richards HB, Supronik J, Dokoupilova E, Mazurov V et al. Efficacy and safety of secukinumab in patients with rheumatoid arthritis: a phase II, dose-finding, double-blind, randomised, placebo controlled study. Annals of the rheumatic diseases, 2013;72:863-9.

[59] Genovese MC, Greenwald M, Cho CS, Berman A, Jin L, Cameron GS et al. A phase II randomized study of subcutaneous ixekizumab, an anti-interleukin-17 monoclonal antibody, in rheumatoid arthritis patients who were naive to biologic agents or had an inadequate response to tumor necrosis factor inhibitors. Arthritis \& rheumatology (Hoboken, NJ), 2014;66:1693-704.

[60] Bologna C, Jorgensen C, Sany J. Association of methotrexate and corticosteroids in the treatment of patients with rheumatoid arthritis. Clinical and experimental rheumatology, 1996;14:401-6.

[61] Choy EH, Kavanaugh AF, Jones SA. The problem of choice: current biologic agents and future prospects in RA. Nat Rev Rheumatol, 2013;9:154-63.

[62] Woodrick RS, Ruderman EM. Safety of biologic therapy in rheumatoid arthritis. Nat Rev Rheumatol, 2011;7:639-52.

[63] Albani S, Koffeman EC, Prakken B. Induction of immune tolerance in the treatment of rheumatoid arthritis. Nat Rev Rheumatol, 2011;7:272-81.

[64] Yeste A, Takenaka MC, Mascanfroni ID, Nadeau M, Kenison JE, Patel B et al. Tolerogenic nanoparticles inhibit T cell-mediated autoimmunity through SOCS2. Science signaling, 2016;9:ra61.

[65] Dumonde DC, Glynn LE. The production of arthritis in rabbits by an immunological reaction to fibrin. British journal of experimental pathology, 1962;43:373-83.

[66] Brackertz D, Mitchell GF, Mackay IR. Antigen-induced arthritis in mice. I. Induction of arthritis in various strains of mice. Arthritis and rheumatism, 1977;20:841-50.

[67] van den Berg WB, Joosten LA, van Lent PL. Murine antigen-induced arthritis. Methods Mol Med, 2007;136:243-53.

[68] Simon J, Surber R, Kleinstäuber G, Petrow PK, Henzgen S, Kinne RW et al. Systemic Macrophage Activation in Locally-induced Experimental Arthritis. Journal of Autoimmunity, 2001;17:127-36.

[69] Ferraccioli G, Bracci-Laudiero L, Alivernini S, Gremese E, Tolusso B, De Benedetti F. Interleukin-1 $\beta$ and Interleukin-6 in Arthritis Animal Models: Roles in the Early Phase of Transition from Acute to Chronic Inflammation and Relevance for Human Rheumatoid Arthritis. Molecular Medicine, 2010;16:552-7.

[70] Koenders MI, Lubberts E, Oppers-Walgreen B, van den Bersselaar L, Helsen MM, Di Padova FE et al. Blocking of interleukin-17 during reactivation of experimental 
arthritis prevents joint inflammation and bone erosion by decreasing RANKL and interleukin-1. The American journal of pathology, 2005;167:141-9.

[71] Isaacs A, Lindenmann J. Virus interference. I. The interferon. Proc R Soc B, 1957;147:258-67.

[72] Platanias LC. Mechanisms of type-I- and type-II-interferon-mediated signalling. Nat Rev Immunol, 2005;5:375-86.

[73] Gonzalez-Navajas JM, Lee J, David M, Raz E. Immunomodulatory functions of type I interferons. Nat Rev Immunol, 2012;12:125-35.

[74] O'Neill LAJ, Golenbock D, Bowie AG. The history of Toll-like receptors [mdash] redefining innate immunity. Nat Rev Immunol, 2013;13:453-60.

[75] Goodbourn S, Didcock L, Randall RE. Interferons: cell signalling, immune modulation, antiviral response and virus countermeasures. The Journal of general virology, 2000;81:2341-64.

[76] Hervas-Stubbs S, Perez-Gracia JL, Rouzaut A, Sanmamed MF, Le Bon A, Melero I. Direct effects of type I interferons on cells of the immune system. Clinical cancer research : an official journal of the American Association for Cancer Research, 2011;17:2619-27.

[77] Crouse J, Kalinke U, Oxenius A. Regulation of antiviral T cell responses by type I interferons. Nat Rev Immunol, 2015;15:231-42.

[78] Wilson EB, Kidani Y, Elsaesser H, Barnard J, Raff L, Karp CL et al. Emergence of distinct multiarmed immunoregulatory antigen-presenting cells during persistent viral infection. Cell host \& microbe, 2012;11:481-91.

[79] Huber JP, David Farrar J. Regulation of effector and memory T-cell functions by type I interferon. Immunology, 2011;132:466-74.

[80] Kalliolias GD, Ivashkiv LB. Overview of the biology of type I interferons. Arthritis research \& therapy, 2010;12:S1-S.

[81] Bave U, Magnusson M, Eloranta ML, Perers A, Alm GV, Ronnblom L. Fe gamma RIIa is expressed on natural IFN-alpha-producing cells (plasmacytoid dendritic cells) and is required for the IFN-alpha production induced by apoptotic cells combined with lupus IgG. Journal of immunology (Baltimore, Md : 1950), 2003;171:3296-302.

[82] Kirou KA, Lee C, George S, Louca K, Peterson MG, Crow MK. Activation of the interferon-alpha pathway identifies a subgroup of systemic lupus erythematosus patients with distinct serologic features and active disease. Arthritis and rheumatism, 2005;52:1491-503.

[83] Hua J, Kirou K, Lee C, Crow MK. Functional assay of type I interferon in systemic lupus erythematosus plasma and association with anti-RNA binding protein autoantibodies. Arthritis and rheumatism, 2006;54:1906-16.

[84] Nestle FO, Conrad C, Tun-Kyi A, Homey B, Gombert M, Boyman O et al. Plasmacytoid predendritic cells initiate psoriasis through interferon-alpha production. The Journal of experimental medicine, 2005;202:135-43.

[85] Butterfield JH. Interferon treatment for hypereosinophilic syndromes and systemic mastocytosis. Acta haematologica, 2005;114:26-40.

[86] Bendtzen K. Critical Review: Assessment of Interferon- $\beta$ Immunogenicity in Multiple Sclerosis. Journal of Interferon \& Cytokine Research, 2010;30:759-66.

[87] Interferon beta- $1 \mathrm{~b}$ is effective in relapsing-remitting multiple sclerosis. I. Clinical results of a multicenter, randomized, double-blind, placebo-controlled trial. The IFNB Multiple Sclerosis Study Group. Neurology, 1993;43:655-61.

[88] Teige I, Liu Y, Issazadeh-Navikas S. IFN-beta inhibits T cell activation capacity of central nervous system APCs. Journal of immunology (Baltimore, Md : 1950), 2006; 177:3542-53. 
[89] Rudick RA, Ransohoff RM, Peppler R, VanderBrug Medendorp S, Lehmann P, Alam $\mathrm{J}$. Interferon beta induces interleukin-10 expression: relevance to multiple sclerosis. Annals of neurology, 1996;40:618-27.

[90] Katakura K, Lee J, Rachmilewitz D, Li G, Eckmann L, Raz E. Toll-like receptor 9induced type I IFN protects mice from experimental colitis. The Journal of clinical investigation, 2005;115:695-702.

[91] Pena-Rossi C, Schreiber S, Golubovic G, Mertz-Nielsen A, Panes J, Rachmilewitz D et al. Clinical trial: a multicentre, randomized, double-blind, placebo-controlled, dosefinding, phase II study of subcutaneous interferon-beta-la in moderately active ulcerative colitis. Alimentary pharmacology \& therapeutics, 2008;28:758-67.

[92] Pena Rossi C, Hanauer SB, Tomasevic R, Hunter JO, Shafran I, Graffner H. Interferon beta-1a for the maintenance of remission in patients with Crohn's disease: results of a phase II dose-finding study. BMC gastroenterology, 2009;9:22.

[93] Gasche C, Reinisch W, Vogelsang H, Potzi R, Markis E, Micksche M et al. Prospective evaluation of interferon-alpha in treatment of chronic active Crohn's disease. Digestive diseases and sciences, 1995;40:800-4.

[94] Gattorno M, Chicha L, Gregorio A, Ferlito F, Rossi F, Jarrossay D et al. Distinct expression pattern of IFN-alpha and TNF-alpha in juvenile idiopathic arthritis synovial tissue. Rheumatology (Oxford, England), 2007;46:657-65.

[95] Hopkins SJ, Meager A. Cytokines in synovial fluid: II. The presence of tumour necrosis factor and interferon. Clinical and experimental immunology, 1988;73:88-92.

[96] van der Pouw Kraan TCTM, Wijbrandts CA, van Baarsen LGM, Voskuyl AE, Rustenburg F, Baggen JM et al. Rheumatoid arthritis subtypes identified by genomic profiling of peripheral blood cells: assignment of a type I interferon signature in a subpopulation of patients. Annals of the rheumatic diseases, 2007;66:1008-14.

[97] Sigurdsson S, Goring HH, Kristjansdottir G, Milani L, Nordmark G, Sandling JK et al. Comprehensive evaluation of the genetic variants of interferon regulatory factor 5 (IRF5) reveals a novel $5 \mathrm{bp}$ length polymorphism as strong risk factor for systemic lupus erythematosus. Hum Mol Genet, 2008;17:872-81 Epub 2007 Dec 6.

[98] van Holten J, Smeets TJ, Blankert P, Tak PP. Expression of interferon beta in synovial tissue from patients with rheumatoid arthritis: comparison with patients with osteoarthritis and reactive arthritis. Ann Rheum Dis, 2005;64:1780-2.

[99] Smeets TJ, Barg EC, Kraan MC, Smith MD, Breedveld FC, Tak PP. Analysis of the cell infiltrate and expression of proinflammatory cytokines and matrix metalloproteinases in arthroscopic synovial biopsies: comparison with synovial samples from patients with end stage, destructive rheumatoid arthritis. Annals of the rheumatic diseases, 2003;62:635-8.

[100] van Holten J, Pavelka K, Vencovsky J, Stahl H, Rozman B, Genovese M et al. A multicentre, randomised, double blind, placebo controlled phase II study of subcutaneous interferon beta-1a in the treatment of patients with active rheumatoid arthritis. Annals of the rheumatic diseases, 2005;64:64-9.

[101] Passos de Souza E, Evangelista Segundo PT, Jose FF, Lemaire D, Santiago M. Rheumatoid arthritis induced by alpha-interferon therapy. Clin Rheumatol, 2001;20:297-9.

[102] Nadir F, Fagiuoli S, Wright HI, Nadir A, Hopp E, Gavaler J et al. Rheumatoid arthritis: a complication of interferon therapy. J Okla State Med Assoc, 1994;87:22830 .

[103] Magnusson M, Zare F, Tarkowski A. Requirement of type I interferon signaling for arthritis triggered by double-stranded RNA. Arthritis and rheumatism, 2006;54:14857. 
[104] Zare F, Bokarewa M, Nenonen N, Bergstrom T, Alexopoulou L, Flavell RA et al. Arthritogenic properties of double-stranded (viral) RNA. Journal of immunology (Baltimore, Md : 1950), 2004;172:5656-63.

[105] van Baarsen LG, Bos WH, Rustenburg F, van der Pouw Kraan TC, Wolbink GJ, Dijkmans BA et al. Gene expression profiling in autoantibody-positive patients with arthralgia predicts development of arthritis. Arthritis and rheumatism, 2010;62:694704.

[106] Lübbers J, Brink M, van de Stadt LA, Vosslamber S, Wesseling JG, van Schaardenburg D et al. The type I IFN signature as a biomarker of preclinical rheumatoid arthritis. Annals of the rheumatic diseases, 2013;72:776-80.

[107] Kiefer K, Oropallo MA, Cancro MP, Marshak-Rothstein A. Role of type I interferons in the activation of autoreactive B cells. Immunology and cell biology, 2012;90:498504.

[108] YANG D, ARKFELD D, FONG T-L. Development of Anti-CCP-positive Rheumatoid Arthritis Following Pegylated Interferon- $\alpha 2$ a Treatment for Chronic Hepatitis C Infection. The Journal of Rheumatology, 2010;37:1777-.

[109] van Holten J, Reedquist K, Sattonet-Roche P, Smeets TJ, Plater-Zyberk C, Vervoordeldonk MJ et al. Treatment with recombinant interferon-beta reduces inflammation and slows cartilage destruction in the collagen-induced arthritis model of rheumatoid arthritis. Arthritis Res Ther, 2004;6:R239-49 Epub 2004 Mar 23.

[110] Triantaphyllopoulos KA, Williams RO, Tailor H, Chernajovsky Y. Amelioration of collagen-induced arthritis and suppression of interferon-gamma, interleukin-12, and tumor necrosis factor alpha production by interferon-beta gene therapy. Arthritis and rheumatism, 1999;42:90-9.

[111] Ying F, Chalise JP, Narendra SC, Magnusson M. Type I IFN protects against antigeninduced arthritis. European journal of immunology, 2011;41:1687-95.

[112] Chalise J, Narendra S, Paudyal B, Magnusson M. Interferon alpha inhibits antigenspecific production of proinflammatory cytokines and enhances antigen-specific transforming growth factor beta production in antigen-induced arthritis. Arthritis research \& therapy, 2013;15:R143.

[113] Chalise JP, Pallotta MT, Narendra SC, Carlsson B, Iacono A, Namale J et al. IDO1 and TGF-beta Mediate Protective Effects of IFN-alpha in Antigen-Induced Arthritis. Journal of immunology (Baltimore, Md : 1950), 2016.

[114] Sakaguchi S, Miyara M, Costantino CM, Hafler DA. FOXP3+ regulatory T cells in the human immune system. Nat Rev Immunol, 2010;10:490-500.

[115] Jonuleit H, Schmitt E. The Regulatory T Cell Family: Distinct Subsets and their Interrelations. The Journal of Immunology, 2003;171:6323-7.

[116] Sakaguchi S, Sakaguchi N, Asano M, Itoh M, Toda M. Immunologic self-tolerance maintained by activated T cells expressing IL-2 receptor alpha-chains (CD25). Breakdown of a single mechanism of self-tolerance causes various autoimmune diseases. Journal of immunology (Baltimore, Md : 1950), 1995;155:1151-64.

[117] Brunkow ME, Jeffery EW, Hjerrild KA, Paeper B, Clark LB, Yasayko SA et al. Disruption of a new forkhead/winged-helix protein, scurfin, results in the fatal lymphoproliferative disorder of the scurfy mouse. Nature genetics, 2001;27:68-73.

[118] Sojka DK, Huang Y-H, Fowell DJ. Mechanisms of regulatory T-cell suppression - a diverse arsenal for a moving target. Immunology, 2008;124:13-22.

[119] Meng X, Yang J, Dong M, Zhang K, Tu E, Gao Q et al. Regulatory T cells in cardiovascular diseases. Nat Rev Cardiol, 2016;13:167-79. 
[120] Munn DH, Sharma MD, Mellor AL. Ligation of B7-1/B7-2 by human CD4+ T cells triggers indoleamine 2,3-dioxygenase activity in dendritic cells. Journal of immunology (Baltimore, Md : 1950), 2004;172:4100-10.

[121] Thornton AM, Shevach EM. CD4+CD25+ immunoregulatory T cells suppress polyclonal $\mathrm{T}$ cell activation in vitro by inhibiting interleukin 2 production. The Journal of experimental medicine, 1998;188:287-96.

[122] Pandiyan P, Zheng L, Ishihara S, Reed J, Lenardo MJ. CD4+CD25+Foxp3+ regulatory $\mathrm{T}$ cells induce cytokine deprivation-mediated apoptosis of effector CD4+ T cells. Nat Immunol, 2007;8:1353-62.

[123] Piconese S, Pacella I, Timperi E, Barnaba V. Divergent effects of type-I interferons on regulatory T cells. Cytokine Growth Factor Rev, 2015;26:133-41.

[124] de Andrés C, Aristimuño C, de las Heras V, Martínez-Ginés ML, Bartolomé M, Arroyo $\mathrm{R}$ et al. Interferon beta-1a therapy enhances $\mathrm{CD} 4<$ sup $>+</$ sup $>$ regulatory $\mathrm{T}$ cell function: An $<$ em $>$ ex vivo $</$ em $>$ and $<$ em $>$ in vitro $</$ em $>$ longitudinal study in relapsing\&\#x2212;remitting multiple sclerosis. Journal of neuroimmunology;182:20411.

[125] Namdar A, Nikbin B, Ghabaee M, Bayati A, Izad M. Effect of IFN-\&\#xdf; therapy on the frequency and function of $\mathrm{CD} 4<$ sup $>+</$ sup $>\mathrm{CD} 25<$ sup $>+</$ sup $>$ regulatory $\mathrm{T}$ cells and Foxp3 gene expression in relapsing\&\#x2013;remitting multiple sclerosis (RRMS): A preliminary study. Journal of neuroimmunology;218:120-4.

[126] Akiyama M, Ichikawa T, Miyaaki H, Motoyoshi Y, Takeshita S, Ozawa E et al. Relationship between regulatory $\mathrm{T}$ cells and the combination of pegylated interferon and ribavirin for the treatment of chronic hepatitis type C. Intervirology, 2010;53:15460 .

[127] Kanto T, Inoue M, Oze T, Miyazaki M, Sakakibara M, Kakita N et al. Dynamics of regulatory $\mathrm{T}$ cells and plasmacytoid dendritic cells as immune markers for virological response in pegylated interferon- $\alpha$ and ribavirin therapy for chronic hepatitis $\mathrm{C}$ patients. Journal of Gastroenterology, 2012;47:169-78.

[128] Lee SE, Li X, Kim JC, Lee J, Gonzalez-Navajas JM, Hong SH et al. Type I interferons maintain Foxp3 expression and T-regulatory cell functions under inflammatory conditions in mice. Gastroenterology, 2012;143:145-54.

[129] Chen M, Chen G, Deng S, Liu X, Hutton GJ, Hong J. IFN-beta induces the proliferation of $\mathrm{CD} 4+\mathrm{CD} 25+$ Foxp3 + regulatory $\mathrm{T}$ cells through upregulation of GITRL on dendritic cells in the treatment of multiple sclerosis. J Neuroimmunol, 2012;242:39-46.

[130] Yan Y, Zhang G-X, Gran B, Fallarino F, Yu S, Li H et al. IDO upregulates regulatory $\mathrm{T}$ cells via tryptophan catabolite and suppresses encephalitogenic $\mathrm{T}$ cell responses in experimental autoimmune encephalomyelitis. Journal of immunology (Baltimore, Md : 1950), 2010;185:5953-61.

[131] Fallarino F, Grohmann U, You S, McGrath BC, Cavener DR, Vacca C et al. The combined effects of tryptophan starvation and tryptophan catabolites down-regulate $\mathrm{T}$ cell receptor zeta-chain and induce a regulatory phenotype in naive T cells. Journal of immunology (Baltimore, Md : 1950), 2006;176:6752-61.

[132] Curti A, Pandolfi S, Valzasina B, Aluigi M, Isidori A, Ferri E et al. Modulation of tryptophan catabolism by human leukemic cells results in the conversion of CD25into CD25+ T regulatory cells. Blood, 2007;109:2871-7.

[133] Srivastava S, Koch MA, Pepper M, Campbell DJ. Type I interferons directly inhibit regulatory $\mathrm{T}$ cells to allow optimal antiviral $\mathrm{T}$ cell responses during acute $\mathrm{LCMV}$ infection. The Journal of experimental medicine, 2014;211:961-74. 
[134] Pace L, Vitale S, Dettori B, Palombi C, La Sorsa V, Belardelli F et al. APC Activation by IFN- $\alpha$ Decreases Regulatory T Cell and Enhances Th Cell Functions. The Journal of Immunology, 2010;184:5969-79.

[135] Akdis M, Aab A, Altunbulakli C, Azkur K, Costa RA, Crameri R et al. Interleukins (from IL-1 to IL-38), interferons, transforming growth factor beta, and TNF-alpha: Receptors, functions, and roles in diseases. The Journal of allergy and clinical immunology, 2016;138:984-1010.

[136] Pohlers D, Brenmoehl J, Löffler I, Müller CK, Leipner C, Schultze-Mosgau S et al. TGF- $\beta$ and fibrosis in different organs - molecular pathway imprints. Biochimica et Biophysica Acta (BBA) - Molecular Basis of Disease, 2009;1792:746-56.

[137] Kulkarni AB, Huh CG, Becker D, Geiser A, Lyght M, Flanders KC et al. Transforming growth factor beta 1 null mutation in mice causes excessive inflammatory response and early death. Proceedings of the National Academy of Sciences of the United States of America, 1993;90:770-4.

[138] Shull MM, Ormsby I, Kier AB, Pawlowski S, Diebold RJ, Yin M et al. Targeted disruption of the mouse transforming growth factor-beta 1 gene results in multifocal inflammatory disease. Nature, 1992;359:693-9.

[139] Prud'homme GJ. Pathobiology of transforming growth factor beta in cancer, fibrosis and immunologic disease, and therapeutic considerations. Laboratory investigation; a journal of technical methods and pathology, 2007;87:1077-91.

[140] Brabletz T, Pfeuffer I, Schorr E, Siebelt F, Wirth T, Serfling E. Transforming growth factor beta and cyclosporin A inhibit the inducible activity of the interleukin-2 gene in T cells through a noncanonical octamer-binding site. Molecular and cellular biology, 1993;13:1155-62.

[141] Datto MB, Li Y, Panus JF, Howe DJ, Xiong Y, Wang XF. Transforming growth factor beta induces the cyclin-dependent kinase inhibitor p21 through a p53-independent mechanism. Proceedings of the National Academy of Sciences of the United States of America, 1995;92:5545-9.

[142] Hannon GJ, Beach D. p15INK4B is a potential effector of TGF-beta-induced cell cycle arrest. Nature, 1994;371:257-61.

[143] Gorelik L, Fields PE, Flavell RA. Cutting edge: TGF-beta inhibits Th type 2 development through inhibition of GATA-3 expression. Journal of immunology (Baltimore, Md : 1950), 2000;165:4773-7.

[144] Marie JC, Letterio JJ, Gavin M, Rudensky AY. TGF-beta1 maintains suppressor function and Foxp3 expression in CD4+CD25+ regulatory T cells. The Journal of experimental medicine, 2005;201:1061-7.

[145] Chen W, Jin W, Hardegen N, Lei KJ, Li L, Marinos N et al. Conversion of peripheral CD4+CD25- naive T cells to CD4+CD25+ regulatory T cells by TGF-beta induction of transcription factor Foxp3. The Journal of experimental medicine, 2003;198:187586.

[146] Fantini MC, Becker C, Monteleone G, Pallone F, Galle PR, Neurath MF. Cutting edge: TGF-beta induces a regulatory phenotype in CD4+CD25- T cells through Foxp3 induction and down-regulation of Smad7. Journal of immunology (Baltimore, Md : 1950), 2004;172:5149-53.

[147] Korn T, Mitsdoerffer M, Croxford AL, Awasthi A, Dardalhon VA, Galileos G et al. IL-6 controls Th17 immunity in vivo by inhibiting the conversion of conventional T cells into Foxp3+ regulatory T cells. Proceedings of the National Academy of Sciences, 2008;105:18460-5. 
[148] Ohtsuka K, Gray JD, Stimmler MM, Toro B, Horwitz DA. Decreased production of TGF-beta by lymphocytes from patients with systemic lupus erythematosus. Journal of immunology (Baltimore, Md : 1950), 1998;160:2539-45.

[149] Ohtsuka K, Gray JD, Stimmler MM, Horwitz DA. The relationship between defects in lymphocyte production of transforming growth factor- $\beta 1$ in systemic lupus erythematosus and disease activity or severity. Lupus, 1999;8:90-4.

[150] Dang H, Geiser AG, Letterio JJ, Nakabayashi T, Kong L, Fernandes G et al. SLE-like autoantibodies and Sjögren's syndrome-like lymphoproliferation in TGF-beta knockout mice. The Journal of Immunology, 1995;155:3205-12.

[151] Thorbecke GJ, Shah R, Leu CH, Kuruvilla AP, Hardison AM, Palladino MA. Involvement of endogenous tumor necrosis factor alpha and transforming growth factor beta during induction of collagen type II arthritis in mice. Proceedings of the National Academy of Sciences of the United States of America, 1992;89:7375-9.

[152] Allen JB, Manthey CL, Hand AR, Ohura K, Ellingsworth L, Wahl SM. Rapid onset synovial inflammation and hyperplasia induced by transforming growth factor beta. The Journal of experimental medicine, 1990;171:231-47.

[153] Racke MK, Dhib-Jalbut S, Cannella B, Albert PS, Raine CS, McFarlin DE. Prevention and treatment of chronic relapsing experimental allergic encephalomyelitis by transforming growth factor- $\beta 1$. Journal of Immunology, 1991;146:3012-7.

[154] Kuruvilla AP, Shah R, Hochwald GM, Liggitt HD, Palladino MA, Thorbecke GJ. Protective effect of transforming growth factor beta 1 on experimental autoimmune diseases in mice. Proceedings of the National Academy of Sciences of the United States of America, 1991;88:2918-21.

[155] Johns LD, Sriram S. Experimental allergic encephalomyelitis: Neutralizing antibody to TGF $\beta 1$ enhances the clinical severity of the disease. Journal of neuroimmunology, 1993;47:1-7.

[156] Pallotta MT, Orabona C, Volpi C, Vacca C, Belladonna ML, Bianchi R et al. Indoleamine 2,3-dioxygenase is a signaling protein in long-term tolerance by dendritic cells. Nat Immunol, 2011;12:870-8.

[157] Yamamoto S, Hayaishi O. Tryptophan pyrrolase of rabbit intestine. D- and Ltryptophan-cleaving enzyme or enzymes. The Journal of biological chemistry, 1967;242:5260-6.

[158] Soliman H, Mediavilla-Varela M, Antonia S. Indoleamine 2,3-dioxygenase: is it an immune suppressor? Cancer;16:354-9.

[159] Ball HJ, Sanchez-Perez A, Weiser S, Austin CJ, Astelbauer F, Miu J et al. Characterization of an indoleamine 2,3-dioxygenase-like protein found in humans and mice. Gene, 2007;396:203-13.

[160] Prendergast GC, Metz R, Muller AJ, Merlo LMF, Mandik-Nayak L. IDO2 in Immunomodulation and Autoimmune Disease. Frontiers in Immunology, 2014;5.

[161] Scheler M, Wenzel J, Tüting T, Takikawa O, Bieber T, von Bubnoff D. Indoleamine 2,3-Dioxygenase (IDO) : The Antagonist of Type I Interferon-Driven Skin Inflammation? The American journal of pathology, 2007;171:1936-43.

[162] Fujigaki S, Saito K, Sekikawa K, Tone S, Takikawa O, Fujii H et al. Lipopolysaccharide induction of indoleamine 2,3-dioxygenase is mediated dominantly by an IFN-gamma-independent mechanism. European journal of immunology, 2001;31:2313-8.

[163] Yanagawa Y, Iwabuchi K, Onoé K. Co-operative action of interleukin-10 and interferon- $\gamma$ to regulate dendritic cell functions. Immunology, 2009;127:345-53. 
[164] Huang L, Baban B, Johnson BA, 3rd, Mellor AL. Dendritic cells, indoleamine 2,3 dioxygenase and acquired immune privilege. International reviews of immunology, 2010;29:133-55.

[165] Puccetti P, Grohmann U. IDO and regulatory T cells: a role for reverse signalling and non-canonical NF-kappaB activation. Nat Rev Immunol, 2007;7:817-23.

[166] Mellor AL, Sivakumar J, Chandler P, Smith K, Molina H, Mao D et al. Prevention of $\mathrm{T}$ cell-driven complement activation and inflammation by tryptophan catabolism during pregnancy. Nat Immunol, 2001;2:64-8.

[167] Mbongue JC, Nicholas DA, Torrez TW, Kim NS, Firek AF, Langridge WH. The Role of Indoleamine 2, 3-Dioxygenase in Immune Suppression and Autoimmunity. Vaccines, 2015;3:703-29.

[168] Lee GK, Park HJ, Macleod M, Chandler P, Munn DH, Mellor AL. Tryptophan deprivation sensitizes activated $\mathrm{T}$ cells to apoptosis prior to cell division. Immunology, 2002;107:452-60.

[169] Fallarino F, Grohmann U, Vacca C, Bianchi R, Orabona C, Spreca A et al. T cell apoptosis by tryptophan catabolism. Cell death and differentiation, 2002;9:1069-77.

[170] Terness P, Bauer TM, Rose L, Dufter C, Watzlik A, Simon H et al. Inhibition of allogeneic $\mathrm{T}$ cell proliferation by indoleamine 2,3-dioxygenase-expressing dendritic cells: mediation of suppression by tryptophan metabolites. The Journal of experimental medicine, 2002;196:447-57.

[171] Baban B, Chandler PR, Sharma MD, Pihkala J, Koni PA, Munn DH et al. IDO activates regulatory $\mathrm{T}$ cells and blocks their conversion into $\mathrm{T}(\mathrm{H}) 17$-like T cells. Journal of immunology (Baltimore, Md : 1950), 2009;183:2475-83.

[172] Hill M, Tanguy-Royer S, Royer P, Chauveau C, Asghar K, Tesson L et al. IDO expands human $\mathrm{CD} 4+\mathrm{CD} 25$ high regulatory $\mathrm{T}$ cells by promoting maturation of LPStreated dendritic cells. European journal of immunology, 2007;37:3054-62.

[173] Nguyen NT, Kimura A, Nakahama T, Chinen I, Masuda K, Nohara K et al. Aryl hydrocarbon receptor negatively regulates dendritic cell immunogenicity via a kynurenine-dependent mechanism. Proceedings of the National Academy of Sciences of the United States of America, 2010;107:19961-6.

[174] Mezrich JD, Fechner JH, Zhang X, Johnson BP, Burlingham WJ, Bradfield CA. An Interaction between Kynurenine and the Aryl Hydrocarbon Receptor Can Generate Regulatory T Cells. The Journal of Immunology, 2010;185:3190-8.

[175] Baban B, Hansen AM, Chandler PR, Manlapat A, Bingaman A, Kahler DJ et al. A minor population of splenic dendritic cells expressing CD19 mediates IDO-dependent T cell suppression via type I IFN signaling following B7 ligation. Int Immunol, 2005;17:909-19.

[176] Coombes JL, Siddiqui KR, Arancibia-Carcamo CV, Hall J, Sun CM, Belkaid Y et al. A functionally specialized population of mucosal CD103+ DCs induces Foxp3+ regulatory $T$ cells via a TGF-beta and retinoic acid-dependent mechanism. The Journal of experimental medicine, 2007;204:1757-64.

[177] Matteoli G, Mazzini E, Iliev ID, Mileti E, Fallarino F, Puccetti P et al. Gut CD103+ dendritic cells express indoleamine 2,3-dioxygenase which influences $\mathrm{T}$ regulatory/T effector cell balance and oral tolerance induction. Gut, 2010;59:595-604.

[178] Gurtner GJ, Newberry RD, Schloemann SR, McDonald KG, Stenson WF. Inhibition of indoleamine 2,3-dioxygenase augments trinitrobenzene sulfonic acid colitis in mice. Gastroenterology, 2003;125:1762-73.

[179] van der Marel AP, Samsom JN, Greuter M, van Berkel LA, O'Toole T, Kraal G et al. Blockade of IDO inhibits nasal tolerance induction. Journal of immunology (Baltimore, Md : 1950), 2007;179:894-900. 
[180] Hayashi T, Beck L, Rossetto C, Gong X, Takikawa O, Takabayashi K et al. Inhibition of experimental asthma by indoleamine 2,3-dioxygenase. Journal of Clinical Investigation, 2004;114:270-9.

[181] Jasperson LK, Bucher C, Panoskaltsis-Mortari A, Taylor PA, Mellor AL, Munn DH et al. Indoleamine 2,3-dioxygenase is a critical regulator of acute graft-versus-host disease lethality. Blood, 2008;111:3257-65.

[182] Criado G, Simelyte E, Inglis JJ, Essex D, Williams RO. Indoleamine 2,3 dioxygenasemediated tryptophan catabolism regulates accumulation of Th1/Th17 cells in the joint in collagen-induced arthritis. Arthritis and rheumatism, 2009;60:1342-51.

[183] Szanto S, Koreny T, Mikecz K, Glant TT, Szekanecz Z, Varga J. Inhibition of indoleamine 2,3-dioxygenase-mediated tryptophan catabolism accelerates collageninduced arthritis in mice. Arthritis research \& therapy, 2007;9:R50.

[184] Guillot X, Rullé S, Mussard J, Falgarone G. Implication of IDO in RA patients treated by biologics. Annals of the rheumatic diseases, 2011;70:A49-A.

[185] Connolly GP, Duley JA. Uridine and its nucleotides: biological actions, therapeutic potentials. Trends Pharmacol Sci, 1999;20:218-25.

[186] Yamamoto T, Koyama H, Kurajoh M, Shoji T, Tsutsumi Z, Moriwaki Y. Biochemistry of uridine in plasma. Clin Chim Acta, 2011;412:1712-24.

[187] Cansev M, Minbay Z, Goren B, Yaylagul EO, Cetinkaya M, Koksal N et al. Neuroprotective effects of uridine in a rat model of neonatal hypoxic-ischemic encephalopathy. Neurosci Lett, 2013;542:65-70.

[188] Zhao Q, Shatskikh T, Marolewski A, Rusche JR, Holmes GL. Effects of uridine on kindling. Epilepsy \& behavior : E\&B, 2008;13:47-51.

[189] Oh JY, In YS, Kim MK, Ko JH, Lee HJ, Shin KC et al. Protective effect of uridine on cornea in a rabbit dry eye model. Investigative ophthalmology \& visual science, 2007;48:1102-9.

[190] van Groeningen CJ, Peters GJ, Leyva A, Laurensse E, Pinedo HM. Reversal of 5fluorouracil-induced myelosuppression by prolonged administration of high-dose uridine. J Natl Cancer Inst, 1989;81:157-62.

[191] Le TT, Urasaki Y, Pizzorno G. Uridine prevents fenofibrate-induced fatty liver. PLoS One, 2014;9:e87179.

[192] Walker UA, Auclair M, Lebrecht D, Kornprobst M, Capeau J, Caron M. Uridine abrogates the adverse effects of antiretroviral pyrimidine analogues on adipose cell functions. Antiviral therapy, 2006;11:25-34.

[193] Walker UA, Venhoff N, Koch EC, Olschewski M, Schneider J, Setzer B. Uridine abrogates mitochondrial toxicity related to nucleoside analogue reverse transcriptase inhibitors in HepG2 cells. Antiviral therapy, 2003;8:463-70.

[194] Le TT, Urasaki Y, Pizzorno G. Uridine prevents tamoxifen-induced liver lipid droplet accumulation. BMC pharmacology \& toxicology, 2014;15:27.

[195] Evaldsson C, Ryden I, Uppugunduri S. Anti-inflammatory effects of exogenous uridine in an animal model of lung inflammation. International immunopharmacology, 2007;7:1025-32.

[196] Uppugunduri S, Gautam C. Effects of uridine, isomatitol and 4-thiouridine on in vitro cell adhesion and in vivo effects of 4-thiouridine in a lung inflammation model. Int Immunopharmacol, 2004;4:1241-8.

[197] Muller T, Grimm M, de Vieira RP, Cicko S, Durk T, Sorichter S et al. Local administration of uridine suppresses the cardinal features of asthmatic airway inflammation. Clinical and experimental allergy : journal of the British Society for Allergy and Clinical Immunology, 2010;40:1552-60. 
[198] LaBranche TP, Hickman-Brecks CL, Meyer DM, Storer CE, Jesson MI, Shevlin KM et al. Characterization of the KRN cell transfer model of rheumatoid arthritis (KRNCTM), a chronic yet synchronized version of the $\mathrm{K} / \mathrm{BxN}$ mouse. The American journal of pathology, 2010;177:1388-96.

[199] Lee SW, Kim JH, Park YB, Lee SK. Bortezomib attenuates murine collagen-induced arthritis. Annals of the rheumatic diseases, 2009;68:1761-7.

[200] Perfetto SP, Chattopadhyay PK, Roederer M. Seventeen-colour flow cytometry: unravelling the immune system. Nat Rev Immunol, 2004;4:648-55.

[201] Quah BJC, Parish CR. The Use of Carboxyfluorescein Diacetate Succinimidyl Ester (CFSE) to Monitor Lymphocyte Proliferation. Journal of Visualized Experiments : JoVE, 2010:2259.

[202] Lahl K, Sparwasser T. In vivo depletion of FoxP3+ Tregs using the DEREG mouse model. Methods in molecular biology (Clifton, NJ), 2011;707:157-72.

[203] Lahl K, Loddenkemper C, Drouin C, Freyer J, Arnason J, Eberl G et al. Selective depletion of Foxp3+ regulatory T cells induces a scurfy-like disease. J Exp Med, 2007;204:57-63 Epub 2007 Jan 2.

[204] Gasser T, Moyer JD, Handschumacher RE. Novel single-pass exchange of circulating uridine in rat liver. Science (New York, NY), 1981;213:777-8.

[205] Darnowski JW, Handschumacher RE. Tissue uridine pools: evidence in vivo of a concentrative mechanism for uridine uptake. Cancer research, 1986;46:3490-4.

[206] Evaldsson C, Ryden I, Uppugunduri S. Anti-inflammatory effects of exogenous uridine in an animal model of lung inflammation. Int Immunopharmacol, 2007;7:1025-32 Epub 2007 Apr 24.

[207] Zhang XW, Schramm R, Liu Q, Ekberg H, Jeppsson B, Thorlacius H. Important role of CD18 in TNF- $\alpha$-induced leukocyte adhesion in muscle and skin venules in vivo. Inflamm res, 2000;49:529-34.

[208] Mojcik CF, Shevach EM. Adhesion molecules. A rheumatologic perspective. Arthritis \& Rheumatism, 1997;40:991-1004.

[209] Jongbloed SL, Lebre MC, Fraser AR, Gracie JA, Sturrock RD, Tak PP et al. Enumeration and phenotypical analysis of distinct dendritic cell subsets in psoriatic arthritis and rheumatoid arthritis. Arthritis research \& therapy, 2006;8:R15.

[210] Zvaifler NJ, Steinman RM, Kaplan G, Lau LL, Rivelis M. Identification of immunostimulatory dendritic cells in the synovial effusions of patients with rheumatoid arthritis. Journal of Clinical Investigation, 1985;76:789-800.

[211] Ma L, Chan KW, Trendell-Smith NJ, Wu A, Tian L, Lam AC et al. Systemic autoimmune disease induced by dendritic cells that have captured necrotic but not apoptotic cells in susceptible mouse strains. European journal of immunology, 2005;35:3364-75.

[212] Lövgren T, Eloranta ML, Båve U, Alm GV, Rönnblom L. Induction of interferonalpha production in plasmacytoid dendritic cells by immune complexes containing nucleic acid released by necrotic or late apoptotic cells and lupus IgG. Arthritis and rheumatism, 2004;50:1861-72.

[213] Blanco P, Palucka AK, Pascual V, Banchereau J. Dendritic cells and cytokines in human inflammatory and autoimmune diseases. Cytokine and Growth Factor Reviews, 2008;19:41-52.

[214] Montoya M, Schiavoni G, Mattei F, Gresser I, Belardelli F, Borrow P et al. Type I interferons produced by dendritic cells promote their phenotypic and functional activation. Blood, 2002;99:3263-71.

[215] Nacu N, Luzina IG, Highsmith K, Lockatell V, Pochetuhen K, Cooper ZA et al. Macrophages produce TGF-beta-induced (beta-ig-h3) following ingestion of apoptotic 
cells and regulate MMP14 levels and collagen turnover in fibroblasts. Journal of immunology (Baltimore, Md : 1950), 2008;180:5036-44.

[216] Kang HK, Liu M, Datta SK. Low-dose peptide tolerance therapy of lupus generates plasmacytoid dendritic cells that cause expansion of autoantigen-specific regulatory $\mathrm{T}$ cells and contraction of inflammatory Th17 cells. Journal of immunology (Baltimore, Md : 1950), 2007;178:7849-58.

[217] Belladonna ML, Orabona C, Grohmann U, Puccetti P. TGF-beta and kynurenines as the key to infectious tolerance. Trends in molecular medicine, 2009;15:41-9.

[218] Puccetti P. On watching the watchers: IDO and type I/II IFN. European journal of immunology, 2007;37:876-9.

[219] Mellor AL, Baban B, Chandler PR, Manlapat A, Kahler DJ, Munn DH. Cutting edge: $\mathrm{CpG}$ oligonucleotides induce splenic CD19+ dendritic cells to acquire potent indoleamine 2,3-dioxygenase-dependent $\mathrm{T}$ cell regulatory functions via IFN Type 1 signaling. Journal of immunology (Baltimore, Md : 1950), 2005;175:5601-5.

[220] Xu H, Zhang GX, Ciric B, Rostami A. IDO: a double-edged sword for T(H)1/T(H)2 regulation. Immunology letters, 2008;121:1-6.

[221] Mezrich JD, Fechner JH, Zhang X, Johnson BP, Burlingham WJ, Bradfield CA. An interaction between kynurenine and the aryl hydrocarbon receptor can generate regulatory T cells. Journal of immunology (Baltimore, Md : 1950), 2010;185:3190-8.

[222] Yun TJ, Lee JS, Machmach K, Shim D, Choi J, Wi YJ et al. Indoleamine 2,3Dioxygenase-Expressing Aortic Plasmacytoid Dendritic Cells Protect against Atherosclerosis by Induction of Regulatory T Cells. Cell metabolism, 2016;23:852-66.

[223] Bailey-Bucktrout SL, Caulkins SC, Goings G, Fischer JA, Dzionek A, Miller SD. Cutting edge: central nervous system plasmacytoid dendritic cells regulate the severity of relapsing experimental autoimmune encephalomyelitis. Journal of immunology (Baltimore, Md : 1950), 2008;180:6457-61.

[224] Manches O, Munn D, Fallahi A, Lifson J, Chaperot L, Plumas J et al. HIV-activated human plasmacytoid DCs induce Tregs through an indoleamine 2,3-dioxygenasedependent mechanism. The Journal of clinical investigation;118:3431-9.

[225] Sharma MD, Baban B, Chandler P, Hou DY, Singh N, Yagita H et al. Plasmacytoid dendritic cells from mouse tumor-draining lymph nodes directly activate mature Tregs via indoleamine 2,3-dioxygenase. The Journal of clinical investigation, 2007; 117:2570-82.

[226] Munn DH, Sharma MD, Baban B, Harding HP, Zhang Y, Ron D et al. GCN2 kinase in $\mathrm{T}$ cells mediates proliferative arrest and anergy induction in response to indoleamine 2,3-dioxygenase. Immunity, 2005;22:633-42.

[227] Pan ZJ, Horton CG, Lawrence C, Farris AD. Plasmacytoid dendritic cells and type 1 interferon promote peripheral expansion of forkhead box protein $3+$ regulatory $\mathrm{T}$ cells specific for the ubiquitous RNA-binding nuclear antigen La/Sjögren's syndrome (SS)B. Clinical \& Experimental Immunology, 2016;186:18-29.

[228] Chen W, Liang X, Peterson AJ, Munn DH, Blazar BR. The indoleamine 2,3dioxygenase pathway is essential for human plasmacytoid dendritic cell-induced adaptive T regulatory cell generation. Journal of immunology (Baltimore, Md : 1950), 2008;181:5396-404.

[229] Hadaschik EN, Enk AH. TGF-beta1-induced regulatory T cells. Human immunology, 2015;76:561-4.

[230] Wang D, Ghosh D, Islam SM, Moorman CD, Thomason AE, Wilkinson DS et al. IFN-beta Facilitates Neuroantigen-Dependent Induction of CD25+ FOXP3+ Regulatory T Cells That Suppress Experimental Autoimmune Encephalomyelitis. Journal of immunology (Baltimore, Md : 1950), 2016;197:2992-3007. 


\section{Papers}

The articles associated with this thesis have been removed for copyright reasons. For more details about these see:

http://urn.kb.se/resolve? urn:nbn:se:liu:diva-136238 